\title{
Morfologia dos frutos e sementes dos gêneros da tribo Mimoseae (Leguminosae-Mimosoideae) aplicada à sistemática
}

\section{Marli Pires Morim de Lima}

Fundação Instituto Brasileiro de Geografia e Estatística (IBGE)/Jardim Botânico do Rio de Janeiro

Dissertação de Mestrado apresentada à Coordenação do Curso da Pós-Graduação em Botánica da UFRJ.

\section{Agradecimentos}

A Dra. Graziela M. Barroso, pesquisadora do Jardim Botânico do Rio de Janeiro, por sua orientaçăo e incentivo.

Aos botânicos Abigail F. Ribeiro de Souza, André Maurício de Carvalho, Ana Maria G. de Carvalho, Angela Maria S. da Fonseca Vaz, Ariane L. Peixoto, Gwilym P. Lewis, Haroldo C. de Lima, Jorge P.P. Carauta, Maria da Conceição Valente, Mitzi Brandão Ferreira, Nilda Marquete F. da Silva, Regina Helena P. Andreata, por sugestర̋es, críticas $\theta$ apoio durante a elaboraçăo do trabalho.

Aos Curadores e Responsáveis das Instituiçőes e Herbários citados, pelo empréstimo do material botånico. Ao CNPq pela bolsa concedida durante o curso de Mestrado.

$O$ presente trabalho consiste no estudo morfológico dos frutos, sementes e embriões de quinze gêneros da triboMimoseae Bronn (Leguminosae-Mimosoideae) ocorrentes no Brasil. Os taxons em relação a tais estruturas, são descritos através de diagnoses $e$ identificados por uma chave dicotómica.

Os frutos são classificados em oito tipos considerando-se, principalmente, as formas deiscentes ou indeiscentes, a morfologia do pericarpo e a presença ou não de replum. Em relação às sementes distinguem-se dois grupos: sementes aladas e não aladas. Quanto ao embrião destaca-se a plúmula que, quando diferenciada em pinas, constitui um bom caráter taxonómico utilizado no reconhecimento de alguns gêneros.

\section{Introdução}

Na família Leguminosae subfamília Mimosoideae os caracteres vegetativos eflorais, nos quais o estudo sistemático de Angiospermae é fundamentalmente baseado, nem sempre são suficientes para a caracterização de alguns taxa. Por este motivo os frutos e sementes vêm sendo utilizados como caracteres decisivos, sem os quais, muitas vezes, torna-se difícil o reconhecimento de determinados gêneros. Por outro lado, observa-se que, geralmente, as descrições morfológicas de tais estruturas, ou são muito amplas a nível de subfamília, ou são encontradas de formas dispersas em breves diagnoses genéricas.

Com o objetivo de auxiliar na sistemática de grupos afins escolheu-se como primeiro passo, o estudo morfológico dos frutos, das sementes e dos embrióes dos gêneros da tribo Mimoseae Bronn ocorrentes no Brasil. Esta tribo, entre as outras quatro da subfamília Mimosoideae, é a que apresenta uma variação maior de padrões de frutos, além de ser a mais representativa na flora brasileira. $O$ conceito de tribo foi adotado segundo Lewis e Elias (1981).

\section{Revisão Bibliográfica}

O primeiro a estudar mais detalhada- mente a morfologia do fruto e da semente de diversas famílias, inclusive Leguminosae, foi, provavelmente, Gaertner (1791). Para os vários gêneros estudados, descreve o "legume" e as estruturas externas e internas da semente.

As características do embrião, mais precisamente a posição do eixo hipocótiloradícula, foram utilizadas por De Candolle (1825) para dividir a família Leguminosae em dois grandes grupos: "Curvembriae", caracterizando-se pelo eixo hipocótilo-radícula inflexo, e "Retembriae", pelo eixo hipocótilo-radícula reto. Ao primeiro grupo subordinou os gêneros de Papilionaceae e Swartzieae, e ao segundo os de Mimoseae e Caesalpineae. Em sua diagnose para a família, inclui descrições sobre os frutos, as sementes e os embriőes.

Baseando-se, entre outros caracteres, na presença ou ausência de endosperma, Bentham (1875), cria a tribo Piptadenieae. Considera como caráter importante e constante na separação de grupos relativamente naturais, a morfologia do fruto, destando entre outros caracteres carpológicos, as formações de replum e artículos. Sua obra, além do estudo taxonómico; contém ilustrações de alguns tipos de "legumes" da referida subordem. Posteriormente (1876), ao tratar da subfamília Mimosoideae na Flora Brasiliensis, inclui, em suas diagnoses genéricas, descrições mi- 
nuciosas sobre os "legumes" dos gêneros da tribo Mimoseae, que eram subordinados, naquela época, às tribos Adenanthereae e Eumimoseae. Em relação às sementes, refere-se, geralmente, a sua forma, posição no fruto e à presença ou não de tecidos de reserva.

Ao estudar a sistemática das Leguminosas da Argentina, Burkart (1943) aborda, entre outros aspectos, a morfologia do fruto e da semente. Em relação ao fruto, caracteriza o legume e define outros nove tipos ocorrentes na família, utilizando em sua classificação uma terminologia específica. Quanto à semente, descreve as estruturas externas e internas, relacionando as primeiras com as respectivas origens no óvulo. Baseando-se nas características dos frutos e das sementes, apresenta uma chave para a identificação de espécies de Papilionoideae.

O estudo de sementes de Leguminosae da Argentina prossegue com Boelcke (1946), que analisa, detalhadamente, as estruturas externas e internas das sementes de oitenta e cinco espécies de Mimosoideae e Caesalpinoideae. Elabora, ainda, uma chave para a identificação dos respectivos taxa.

A morfologia interna das sementes de Angiospermae e Gimnospermae foi tratada por Martin (1946) que classificou para as famílias destes dois grandes grupos do reino vegetal, doze tipos de embriões, considerando a forma, o tamanho e a posição. Estudou nove gêneros de Mimosoideae e determinou o embrião como pertencente ao tipo invaginado.

A importância do estudo morfológico da semente na taxonomia dos Angiospermae é ressaltada por Isely (1947) que analisa os componentes externos e internos das sementes de diversas famílias de Dicotiledoneae e Monocotiledoneae dos Estados Unidos. Em sua chave analítica, descreve os caracteres das famílias estudadas. Em sua descrição para as subfamílias Mimosoideae e Caesalpinoideae, fornece dados gerais sobre as diversas formas de sementes, superfície da testa, posição do hilo e estruturas embrionárias. Posteriormente (1955a), elabora uma chave para a identificação das sementes de algumas espécies das subfamílias acima citadas. Um dos caracteres principais utilizados para separá-ias é a presença ou ausência da "face line" e a forma da "face area", que são denominações atribuídas pelo autor à linha em forma de ferradura existente em cada face da semente e à respectiva área que ocupa. Dando continuidade aos seus estudos, Isely (1955b), após descrever a morfologia externa e interna das sementes de Mimosoideae e Caesalpinoideae, conclui que, para ambas as subfamílias, a estrutura da semente é basicamente a mesma.

A composiçăo anatômica das sementes de Leguminosae é analisada por Corner (1951) que destaca como principais características a presença de células paliçádicas e as células em forma de ampulheta. Reconhece, além das três subfamílias tradicionalmente conhecidas, a Swartizoideae, na qual, segundo o autor, a estrutura da semente é intermediária entre as Papilionoideae e as Mimosoideae-Caesalpinoideae. Ao descrever as sementes de cada uma das respectivas subfamílias, denomina pleurograma à marca existente na testa da maioria das sementes de Mimosoideae. Apresenta, ainda, um estudo das sementes excessivamente grandes, "overgrown seeds", as quais são caracterizadas pela testa não diferenciada. Em trabalho mais recente (1976), seus estudos são ampliados a diversas famílias de Dicotiledoneae, e a estrutura das sementes de Leguminosae é novamente abordada.

Ao tratar da sistemática de alguns gêneros de Mimosoideae, Brenan (1955) observa que entre as espécies de Piptadenia há uma grande variação nas formas de deiscência da "vagem" e, também, na morfologia da semente. Baseando-se, principalmente, nos diferentes aspectos morfológicos dos frutos e sementes, propõe a divisão de Piptadenia s.l. em oito gêneros, entre os quais Anadenanthera, Goldmania, Pseudopiptadenia (como Monoschisma) Newtonia, Piptadenia e Pityrocarpa, que possuem espécies ocorrentes no Brasil. Em trabalho posterior (1963), devido a problemas de tipificação, 0 autor realiza as seguintes alterações nomenclaturiais: $P y$ tyrocarpa passa a Piptadenia e duas das espécies de Piptadenia, $P$. pterosperma e $P$. rigida, passam a Parapiptadenia.

Os frutos dos Angiospermae são classificados por Hertel (1959) em cinco unidades, que seguem uma seqüência hierárquica semelhante a utilizada na sistemáti$\mathrm{ca}$, as quais recebem desinências específicas. Assim, o fruto de Leguminosae, juntamente com outras famílias, é considerado como pertencente a classe dos Eucarpos. Através de sua chave para a classificação tipológica, caracteriza o legume e os frutos de Mimosa e Schrankia.

Com o estudo da morfologia das sementes das três subfamílias de Leguminosae, Kopooshian e Isely (1966) fortalecem a hipótese que as Papilionoideae ori- ginaram-se das Caesalpinoideae, afastando qualquer relacionamento da primeira subfamília com as Mimosoideae.

As sementes e os embriōes de dezoito gêneros de Mimosoideae, ocorrentes na Venezuela, são descritos por Bravato (1974) que relaciona, ainda, as diferenças entre as sementes das três subfamílias de Leguminosae. Os taxons estudados são diferenciados por uma chave baseada, fun. damentalmente, nos aspectos morfológi$\cos$ das sementes e dos embriões. Em relação ao fruto, limita-se a definir os diferentes tipos, segundo a classificação de Burkart (1943).

As estruturas morfológicas externas e internas das sementes de diversas famílias de Dicotiledoneae e Monocotiledoneae, foram analisadas e descritas por Barroso (1976). Em trabalho posterior, (1978), dando continuidade ao estudo de identificação de sementes, define os diferentes tipos de reservas do endosperma e classifica os embriões de acordo com suas respectivas formas e posições que ocupam no interior da semente. Seguindo a classificação de Martin (1964) considera o embrião de Mimosoideae como pertencente ao tipo invaginado.

Barroso e Col. (1984) definem onze tipos de frutos ocorrentes na família Leguminosae. Aceitam a terminologia de Burkart (1943) e relacionam todos os tipos de frutos dos gêneros de Mimosoideae, definindo-os em relaçăo a forma de deis cência, consistência e diferenciação do endocarpo. Além da morfologia do fruto, baseando-se no trabalho de Corner (1951), descrevem a estrutura anatômica da testa e os aspectos externos e internos da semente. Ressaltam, ainda, que entre os caracteres embrionários, a plúmula pode ser utilizada na identificação de gêneros.

A ampliação da definiçăo do termo legu. me é proposta por Dudik (1981), com o intuito de que todos os tipos de frutos encontrados em Leguminales, principalmente os raros casos de "multilegumem", sejam enquadrados em uma classificação carpológica sob a denominação genérica de legume. Classifica os diferentes tipos de legume e estabelece para os frutos e sementes dezesseis critérios de primitividade e especialização. Representa, ainda, através de um diagrama, as tendências evolucionárias das vagens de Leguminales.

As sementes de Leguminosae foram estudadas mais recentemente por Gunn (1981), que considera a composição anatômica da testa, uma característica mar- 
cante entre os diferentes taxa desta família. Analisa a morfologia e a anatomia das estruturas das sementes nas três subfamílias, estabelecendo as respectivas diferenças entre Mimosoideae-Caesalpinoideae e Papilionoideae. Entre outros componentes, aborda o pleurograma em relação a sua ocorrência, ontogenia e provável função, definindo os cinco tipos encontrados em Mimosoideae e Caesalpinoideae. Quanto à presença de sementes aladas, consideraas raras na família.

Além das referências acima mencionadas, os frutos dos gêneros de Mimoseae são descritos sob as denominações gerais de "fruto" ou "legume" nos trabalhos de Hutchinson (1967), Elias (1974) e Lewis e Elias (1981), que tratam da sistemática do grupo. Quanto às sementes, suas citações são muito breves.

As demais obras, puramente sistemáticas, serão abordadas oportunamente no decorrer deste trabalho.

\section{Materiais e Métodos}

Os exemplares frutíferos, que serviram de base para este estudo, pertencem, em sua grande maioria, às coleções depositadas nos herbários do Jardim Botânico do Rio de Janeiro (RB) e às do Museu Nacional da Universidade Federal do Rio de Janeiro (R). Quando estas coleções não continham exemplares frutíferos ou estes eram escassos, recorreu-se aos herbários da Universidade Estadual de Campinas (UEC), Centro de Pesquisa Agropecuária do Trópico Umido-EMBRAPA (IAN), Museu Emílio Goeldi (MG) e Herbário Bradeanum (HB).

Para a citação do material, foram selecionados os exemplares nos quais frutos $\mathrm{e}$ sementes se encontravam em boas condições de conservação e desenvolvimento. Em algumas espécies, apenas o fruto foi examinado devido a ausência ou más condições das sementes, usando-se, nestes casos, após a citação do material consultado, a sigla S/S. Em relação ao gênero monotípico Dinizia Ducke, por falta de material, a descrição da semente está baseada apenas na diagnose do autor.

A germinação das sementes das espécies dos gêneros Anadenanthera, Desmanthus, Pseudopiptadenia, Newtonia, Parapiptadenia e Stryphnodendron, foi obtida com sementes coletadas no Parque do Jardim Botânico do Rio de Janeiro, nas matas da Vista Chinesa ou provenientes da Empresa de Pesquisa Agropecuária de Minas Gerais (EPAMIG). As sementes foram colocadas em lotes, de 5 e 10 unidades, em placas de Petri previamente forradas com algodão e papel de filtro, expostas à tempera ambiental e umedecidas com água potável.

Para o estudo das características morfológicas dos frutos, sementes e embriões, foram analisados os seguintes caracteres:

Fruto: deiscente ou indeiscente, morfologia do pericarpo (seco ou carnoso, segmentado ou não), forma, tamanho, consistência, quantidade de sementes, superfície (coloração, polimento, configuração e indumento), base, ápice e margens.

Semente: tamanho, forma, presença ou não de ala, posição no fruto, presença ou não de endosperma, superfície da testa (consistência, coloração e polimento), forma do pleurograma, funículo, hilo e micrópila.

De acordo com a definição de Murley (1951), "base é o extremo de qualquer órgão pelo qual ele está unido a seu suporte e por onde se dá a nutriçăo", foi considerada a base da semente o local onde se situa o hilo.

Embrião: tamanho, forma, consistência e grau de diferenciação da plúmula.

Todos os caracteres morfológicos da semente e do embrião foram analisados após a reidratação por fervura em água. Realizaram-se secções transversais com lâmina de aço, principalmente para observar-se a consistência e quantidade de endosperma em relação ao tamanho do embrião e à posição deste no interior da semente.

A terminologia utilizada para as diferentes estruturas morfológicas está baseada nos seguintes trabalhos: Rizzini (1977), adaptados às formas dos frutos, Murley (1951) e Stearn (1966), formas das sementes e embriões, Burkart (1943), Font Quer (1975) e Barroso (1984), classificação e terminologia dos frutos, Lawrence (1951) e Rizzini (1977), tipos de indumento.

Os significados das abreviaturas utilizadas, são relacionados abaixo:

s.I. = sem localidade.

s.n. = sem número.

s.d. = sem data.

$\mathrm{S} / \mathrm{S}=$ sem semente.

\section{Resultados}

\section{Considerações Gerais sobre a Morfologia dos Frutos, Sementes e Embriões da Tribo Mimoseae.}

\section{Fruto}

Os frutos em Mimoseae originam-se de um ovário monocarpelar, súpero, unilocular e com muitos ou poucos óvulos inseridos em placenta marginal. Quando maduros, tendem geralmente às formas lineares, oblongas ou cilíndricas, com faces planas ou convexas, de consistência cartácea ou, mais raramente, sublenhosa em espécies de Newtonia e Mimosa. Geralmente, exceto o estilete e em algumas espécies o cálice, as demais estruturas florais não persistem no fruto.

O tamanho varia de 1 a $39 \mathrm{~cm}$ de comprimento, sèndo que dimensões inferiores a $5 \mathrm{~cm}$ foram encontradas com maior freqüência apenas em espécies de Desmanthus, Mimosa e Neptunia, enquanto que em espécies de Anadenanthera, Dinizia, Entada, Pseudopiptadenia, Newtonia, Plathymenia e Prosopis os frutos podem alcançar mais de $25 \mathrm{~cm}$ de comprimento.

Quanto ao número de sementes, os frutos são tipicamente polispérmicos, sendo que apenas em algumas espécies de Mimosa foram observados alguns monospérmicos ou com número de sementes inferior a cinco.

A superfície é lisa, venosa, verrucosa ou glandulosa, glabra ou revestida por tipos de indumento, que, principalmente, em certas espécies de Mimosa, são característicos e peculiares. Em relação ainda a este gênero a coloração dos frutos secos que nos demais taxa varia de pardacenta a nigrescente, pode apresentar-se de um intenso amarelo ouro.

A base pode ser séssil ou estipitada e o ápice, geralmente marcado pela presença do estilete, varia de obtuso a curto ou longamente acuminado. A formação marcante de um rostro é característica no fruto de Schrankia leptocarpa (foto 20).

As margens, as quais variam de retas a constrictas, diferenciam-se ou não em replum.

Entre todos os caracteres morfológicos analisados, as variações nas formas de deiscência e na morfologia das camadas que compõem o pericarpo, são fundamentais para o reconhecimento dos oito tipos de frutos encontrados nesta tribo. As definições de cada um dos tipos e respectivas ocorrências estão relacionadas abaixo:

1 - Folículo: Fruto seco deiscente apenas na sutura do carpelo, permanecendo as valvas unidas na região dorsal.

Ocorre em Anadenathera (fotos 28, 29), Goldmania paraguensis (foto 25), Pseudopiptadenia (foto 26), Newtonia (foto 27), e Stryphnodendron gracile (foto 24 ). 
2 - Legume: Fruto seco, deiscente dorsiventralmente, com a formação de duas valvas.

Ocorre em: Desmanthus (foto 35), Neptunia (foto 36), Parapiptadenia (fotos 33, 34) e Piptadenia (foto 31,32 ).

3 - Sacelo: Fruto seco com deiscência transversoapical, com pseudoreplum unilateral, caduco, permanecendo as valvas unidas entre si. O nome foi proposto por Mannagetta (1913).

Ocorre em: Mimosa acerba (foto 7) e Mimosa meticulosa.

4 - Legume carnoso: Fruto carnoso indeiscente ou tardiamente deiscente na sutura do carpelo e, mais tarde, dorsiventralmente, com meso e/ou endocarpo carnoso com septos transversais ou oblíquos entre as sementes.

Ocorre em: Stryphnodendron spp (fotos 22, 23).

5 - Criptolomento: Fruto seco, constituído por duas partes, uma externa (epicarpo-mesocarpo) deiscente, formando duas valvas como no legume, e a outra (endocarpo) indeiscente segmentado, originando artículos monospérmicos.

Ocorre em: Plathymenia (foto 30).

6 - Craspédio: Fruto seco, deiscente ou indeiscente, caracterizandose principalmente pela presença do replum, isto é, as margens são persistentes como uma moldura que se destaca das faces segmentadas ou não do fruto. Foram observadas, ainda, as seguintes diferenciações.

a) Craspédio deiscente indiviso: com pericarpo indiviso, formando duas valvas geralmente decíduas.

Ocorre em: Mimosa claussenii (foto 8), Mimosa incana, Mimosa micropteris (foto 9), Mimosa pachycarpa (foto 10) e Mimosa pseudo-obovata (foto 11).

b) Craspédio deiscente ou indeiscente articulado: com o pericarpo segmentado formando artículos monospérmicos.

Ocorre em Entada (foto 21) e Mimosa spp (foto 12, 19).

c) Craspédio deiscente: com o pericarpo segmentado, porém sem formar artículos monospérmicos.
Ocorre em: Schrankia leptocarpa (foto 20).

7 - Lomento drupáceo: Fruto carnoso, indeiscente, com mesocarpo pulposo e o endocarpo coriáceo segmentado em artículos monospérmicos.

Ocorre em: Prosopis (foto 37).

8 - Samaróide: Fruto seco, indeiscente, com uma das margens levemente expandida, assemelhando-se a uma ala unilateral. Ocorre em: Dinizia (foto 38).

Nos frutos de Entada, Plathymenia e Prosopis, o epicarpo e o endocarpo apresentam consistências diferentes entre si, sendo o mesocarpo diferenciado apenas em Prosopis. Por esta razão, nas descrições destes gêneros, as respectivas camadas são tratadas isoladamente. Nos demais frutos, a consistência do pericarpo é uniforme.

\section{Semente}

As sementes de Mimoseae originamse de óvulos anátropos, variam de 0,3 a $5,3 \mathrm{~cm}$ de comprimento, são comprimidas, com faces planas ou convexas e com bordos de arredondados a agudos.

A testa é sempre lisa, sem esculturações, variando de membranácea a rígida, de nítida a opaca e de pardacenta a nigrescente. Apenas em Goldmania paraguensis é branco-acinzentada. Em ambas as faces, a testa pode ser ou não marcada por uma linha, geralmente em forma de ferradura, denominada por Corner (1951), pleurograma - linha de fissura por Boelcke (1946) e "face line" por Isely (1955a). O pleurograma nas sementes de Mimoseae é aberto em direção à região hilar, sendo este grau de abertura bastante variável.

Apenas nas espécies de Plathymenia os braços do pelurograma são quase que totalmente unidos, formando uma estrutura contínua (figs. 8 b e 8 e). Sua classificação foi baseada em relação à região da semente onde está localizado, o que implica em sua maior ou menor extensão, independente do grau de abertura. Assim sendo, os seguintes tipos foram evidenciados:

1 - Pleurograma mediano (fig. 11a): Ocupa principalmente a região mediana da semente, estendendo-se ou não até a região basal.

2 - Pleurograma apical-basal (fig. $11 \mathrm{e})$ : Ocupa quase toda a superfície da semente, isto é, da região apical a basal.
Além do pleurograma, nas sementes de Entada (fig. 4a) e Plathymenia (fig. 8b e 8e), são observadas linhas curvas, contínuas ou não, geralmente mais numerosas no interior da região pleurogramática. Isely (1955b) e Gunn (1981) denominaram-nas linhas de fraturas e, segundo Isely (I.c.), tais formações mais freqüentes em sementes velhas, resultam de rachaduras da testa. Para Gunn (I.c.), as linhas de fraturas são conseqüência de um processo de dissecamento interno.

O funículo é geralmente longo, filiforme e espiralado na região hilar. Em espécies de Piptadenia (figs. $9 \mathrm{~d}$ e $9 \mathrm{~g}$ ) apresenta-se curto e espessado.

O hilo, freqüentemente diminuto, varia de circular a elíptico e localiza-se na região basal sobre o bordo da semente.

A micrópila adjacente ao hilo, raramente, é perceptível.

A rafe, quando distinta, caracteriza-se por uma linha levemente sulcada ou por mancha ou saliência lateral ao hilo.

A chalaza não apresenta caráter morfológico evidente no aspecto externo da semente.

As sementes podem ser providas ou não de ala, caracterizando-se dois grupos distintos:

\section{1 - Sementes aladas:}

A ala em Mimoseae é sempre circular, emarginada na região hilar, membranácea como o restante da testa, podendo ser ampla ou estreita. Neste grupo, as sementes variam de orbiculares a oblongas e, em algumas espécies, transverso-oblongas ou transverso-elípticas. A testa não é marcada por pleurograma.

Ocorre em: Anadenanthera colubrina (fig. 7a), Pseudopiptadenia (fig. 6a), Newtonia (fig. 6e) e Parapiptadenia (fig. 10a).

\section{2 - Sementes não aladas}

Tendem geralmente à forma obovóide ou combinações desta, em conseqüência do estreitamento na região basal, denominado por Gunn (1981) de lobo radicular. onde aloja-se o eixo hipocótilo-radícula. 0 hilo situa-se no lobo radicular. Em todo o grupo de sementes não aladas a testa é marcada or pleurograma. Este grupo de sementes, predominante na tribo, ocorre nas demais espécies de Anadenanthera (fig. 7d) e nos outros doze gêneros de Mimoseae.

A posição da semente em relação ao eixo longitudinal do fruto foi classificada em:

1) Semente longitudinal (foto 32 ): Orientada paralelamente. 
2) Semente transversal (foto 22): Orientada perpendicularmente.

3) Semente Oblíqua (foto 24): Orientada obliquamente.

0 endosperma, após a semente ser submetida a reidratação por fervura em água, apresenta-se com aspecto gelatinoso, amarelado ou translúcido. Sua presença foi verificada, em concentrações variáveis, com maior freqüência, nas sementes nâo aladas. Quando presente nas sementes aladas é bastante escasso.

\section{Embrião}

O embrião é formado por dois cotilédones, eixo hipocótilo-radícula reto e sempre de tamanho inferior ao dos cotilédones e plúmula diferenciada ou não em pinas. Ocupa quase que totalmente a cavidade interna da semente e os cotilédones, plano-convexos, geralmente, membrano-carnosos, são soldados apenas na base sagitada ou sagitada-biauriculada formando um sinus onde se insere totalmente ou parcialmente o eixo hipocótilo-radícula. Foi considerado, segundo a classificação de Barroso (1978), como axial e invaginado em relação respectivamente à posição que ocupa no interior da semente e à delimitação bem pronunciada entre os cotilédones e o eixo.

A plúmula pode ser rudimentar, representada apenas por um segmento bi a tri partido, ou muito desenvolvida devido a formação de vários segmentos alongados. Como descreveu Bravato (1974), as plúmulas multi-segmentadas apresen. : n-se diferenciadas em pinas. Nas plúmulas formadas por segmentos vestigiais, a diferenciação em pinas não é evidente. Em algumas espécies observa-se que os segmentos, em relação ao grau de desenvolvimento, são intermediários entre as formas rudimentares e diferenciadas. Especialmente em Schrankia leptocarpa (fig. 3d) e em algumas espécies de Mimosa, a plúmula é provida de apêndices laterais muito prolongados e que provavelmente estão relacionados com as futuras estípulas. As plúmulas com diferenciação evidente em pinas foram observadas nas espécies dos gêneros: Anadenanthera (fig. $7 \mathrm{~g}$ ). Mimosa p.p. (figs. 2c e 2d), Newtonia (fig. 6h), Parapiptadenia (fig. 10d), Piptadenia p.p. (fig. 9j) e Schrankia (fig. 3d).

\section{Dados Prelimares sobre Germinaçăo}

Apesar dos dados sobre germinação ainda serem escassos e insuficientes para resultados conclusivos, uma vez que o processo sófoi observado em espécies dos gêneros Anadenanthera, Desmanthus, Pseudopiptadenia, Newtonia, Parapiptadenia e Stryphnodendron, o aspecto morfológico das primeiras folhas parece serum bom caráter na diferenciação das respectivas plântulas.

Nas espécies $A$. colubrina, A. macrocarpa, A. peregrina, N. nitida, D. virgatus, P. leptostachya, Parapiptadenia sp. e $S$. adstringens, após a emergência do eixo hipocótilo-radícula, nas proximidades da região hilar, os cotilédones libertam-se da testa, enquanto o hipocótilo distende-se. A germinação foi considerada faneroepigea, segundo as definições de $\mathrm{Ng}$ apud Duke e Polhill (1981). Nas sementes das sete primeiras espécies acima relacionadas, o eixo hipocótilo-radícula surge até o $15 .^{\circ}$ dia. Porém, em $S$. adstringens, o processo de germinação só se inicia cerca de três meses após as sementes terem sido colocadas para germinar. Em Anadenanthera ıspp. N. nitida, Parapiptadenia sp. e S. adstringens, logo após a saída dos cotilédones, emerge o epicótilo com os primeiros eófilos, isto é, segundo Tomlinson (apud Duke (1965 e 1969), as primeiras folhas desenvolvidas pelas plåntulas. $\operatorname{Em} D$. virgatus e $P$. leptostachya o epicótilo com os primeiros eófilos surge cerca de dez dias após a expansão dos cotilédones. Os dois períodos de "repouso" mencionados por Vogel apud Duke e Polhill (1981), isto é, o dos cotilédones erguidos mas ainda cercados pela testa e o dos cotilédones expandidos antes da extensão do epicótiIo, são bem distintos durante o processo germinativo de $D$. virgatus e $P$. leptostachya.

Os primeiros eófilos podem ser pinados ou bipinados. EmAnadenanthera colubrina (foto 1) e $N$. nitida (foto 2) são bipinados com 2 a 4 pares de pinas multifolioladas. $\operatorname{Em} D$. virgatus (foto 3), Parapiptadenia $s p$. (foto 4) e $S$. adstringens (foto 5) são pinados, sendo que as plântulas de $D$. virgatus apresentam, incialmente, apenas um eófilo com 4 pares de folíolos, enquanto que em Parapiptadenia sp. e $S$. adstringens surgem, simultaneamente, dois eófilos. alternos com respectivamente 7 e 4 pares de folíolos. Nestas duas espécies, apenas o segundo eófilo é bipinado.

A plântula de P. leptostachya (foto 6) é bem distinta das plântulas das demais espécies, por seu eófilo bifoliado.

\section{Chave para a Identificação dos Gêneros da Tribo Mimoseae}

1. Fruto deiscente:

2. Replum presente (craspédio).
3. Parede do craspédio formada por artículos monospérmicos deiscentes... .......... 1-Mimosa p.p.

3'. Parede do craspédio não articulada

4. Craspédio tetragonal com parede segmentada. ....2-Schrankia

4'. Craspédio nunca tetragonal, com parede indivisa. . .1 - Mimosa p.p.

2'. Replum ausente.

5. Fruto com deiscência apenas na sutura do carpelo (folículo).

6. Plúmula sem nítida diferenciação em pinas.

7. Folículo não contorcido, com margens de retas a sinuosas.

8. Semente com testa de pardacenta a castanha, pleurograma apicalbasal................. ....4-Stryphnodendron p.p.

8'. Semente com testa branco-acinzentada, pleurograma mediano ..........5 - Goldmania

7'. Folículo contorcido com margens muito constrictas........... .....6-Pseudopiptadenia

6'. Plúmula com nítida diferenciação em pinas.

9. Semente com ala ampla, testa membranácea, sem pleurograma ......... 7 - Newtonia

9:. Semente sem ala, ou raramente com ala muito estreita, testa rígido-membranácea, geralmente com pleurograma.......... ...... 8-Anadenanthera

5'. Fruto com deiscência dorsiventral ou transverso-apical.

10. Fruto com deiscência apical, permanecendo as valvas unidas na base (sacelo) ... 1 - Mimosa p.p.

10. Fruto com deiscência ao longo das valvas, as quais separam-se totalmente (legume).

11. Endocarpo segmentado, formando artículos monospérmicos (criptolomento)........... ........9-Plathymenia

11'. Endocarpo não segmentado.

12. Fruto carnoso, mesocarpo diferenciado (legume carnoso) ................ ...4-Stryphnodendron p.p.

12'. Fruto seco, mesocarpo não diferenciado.

13. Legume com margens muito constrictas . . . . . ....10-Piptadenia p.p.

13'. Legume com margens de retas a sinuosas. 
14. Sementes aladas, sem pleurograma. . . .. 11 - Parapiptadenia

14'. Sementes não aladas, com pleurograma.

15. Sementes com cerca de 0,6 $1,3 \mathrm{~cm}$ de comprimento $\times 0,4-$ $1,3 \mathrm{~cm}$ de largura. Plúmula diferenciada em pinas. . ....10-Piptadenia p.p.

15'. Sementes com cerca de 0,3 $0,5 \mathrm{~cm}$ de comprimento $\times 0,2$ $-0,3 \mathrm{~cm} \mathrm{de}$ largura.

Plúmula sem nítida diferenciação em pinas.

16. Sementes com pleurograma mediano...... ....12Desmanthus

16'. Sementes com pleurograma apicalbasal ....... .... 13 Neptunia

1 . Fruto indeiscente.

17. Fruto com mesocarpo carnoso, diferenciado.

18. Endocarpo segmentado, formando artículos monospérmicos (lomento drupáceo) . . . . . 14-Prosopis

18'. Endocarpo apenas septado, não segmentado (legume carnoso) . . . . 4 - Stryphnodendron p.p.

17 . Fruto com mesocarpo não diferenciado.

19. Fruto com margem unilateralmente expandida em pequena ala (samaróide) . . . . . 15-Dinizia

$19^{\prime}$. Fruto com margem diferenciada em replum (craspédio).

20. Craspédio com cerca de $31,0-39,0 \mathrm{~cm}$ de comprimento, com epicarpo separandose do endocarpo. 3 - Entada

20'. Craspédio com cerca de 0,8 a $17,0 \mathrm{~cm}$ de comprimento, com epicarpo e endocarpo unidos. 1 - Mimosa p.p.
Descrição dos Gêneros

1 - Mimosa Linnaeus Linnaeus, Sp. PI. 1: 516.1753

Fotos: 7-19; Fig. 1-2

Craspédio articulado ou indiviso, raramente sacelo $0,8-17,0 \mathrm{~cm}$ de comprimento $X 0,3-3,0 \mathrm{~cm}$ de largura, oblongo, linear, elíptico, ovalado, lanceolado, linear-oblongo, plano-compresso ou subcilíndrico, reto ou falcado, estipitado $(0,3-2,0 \mathrm{~cm})$ ou séssil, de cartáceo a sublenhoso, pardacento, castanho, ferrugíneo ou amarelo-ouro, opaco ou nítido, venoso, verrucoso ou glanduloso, de glabro a densamente setoso, aculeado ou mais raramente equinado; artículos deiscentes ou indeiscentes, monospérmicos, lineares, de quadrangulares a retangulares ou, raramente, subtriangulares, geralmente com a região seminífera convexa e os bordos aplanados; replum espessado ou não, reto ou constricto, de glabro a setoso, ornado ou não por acúleos.

Semente com 0,3-0,8 cm de comprimento $\times$ 0,2-0,6 cm de largura de obovóide, obovóide-oblonga, suboblonga a oblonga, elipsóide, de suborbicular e orbicular, com faces convexas, não alada, transversal, oblíqua ou longitudinal, com endosper$\mathrm{ma}$; testa de consistência rígido-membranácea a rígida, de pardacenta a nigrescente, nítida, com pleurograma mediano ou apical-basal com braços de afastados a semi-unidos.

Embrião com cotilédones de $0,2-0,7 \mathrm{~cm}$ de comprimento $\times 0,2-0,5 \mathrm{~cm}$ de largura, cordado-obovóides, cordado-suborbiculares, cordado-orbiculares, cordado-oblongos, cordado-elípticos, plano-convexos; eixo hipocótilo-radícula com $0,1-0,3 \mathrm{~cm}$ de comprimento, emergente; plúmula diferenciada em pinas, com apêndices laterais pronunciados ou, plúmula sem nítida diferenciação em pinas, e sem apêndices laterais pronunciados.

Entre as espécies examinadas do gênero Mimosa, foram encontrados dois tipos de frutos: sacelo e craspédio.

$O$ sacelo foi observado apenas em $M$. acerba (foto 7) e $M$. meticulosa, onde os pequeninos e numerosos frutos setosos persistem no capítulo, mesmo após a deiscência, aglomerados em densas "cabecinhas globosas", como mencionou Burkart (1948 e 1979). É provável que em outras espécies, principalmente da série Meticulosae, ocorra este tipo de fruto. 0 sacelo diferencia-se do legume típico por sua deiscência transverso-apical, mantendo-se as valvas unidas, dando a impressão de pequeninas bocas abertas.

O craspédio, considerado por Burkart (1943) como uma variação do lomento, é o tipo de fruto predominante do gênero. Pode apresentar-se indiviso - fruto ao qual Burkart (1948:36) se refere como um retorno do craspédio à forma de vagem típica, deixando, porém, replum - ou seg. mentado em artículos monospérmicos, caracterizando dois grupos de espécies:

- Craspédio com valvas indivisas, deiscentes, persistentes ou decíduas. Observado nas seguintes espécies: $M$. claussenii (foto 8 ), $M$. incana, $M$. micropteris (foto 9), M. pachycarpa (foto 10), M. Pseudo-obovata (foto 11).

- Craspédio segmentado formando de 2 a 20 artículos monospérmicos deiscentes ou indeiscentes. Observado nas demais espécies examinadas (fotos 12-19).

Em $M$. incana e $M$. micropteris, nos exemplares examinados, foram encontra. dos apenas craspédios indivisos, porém, Burkart (1964 e 1979) cita que em ambas as espécies o craspédio, também, pode ser articulado.

Os craspédios apresentam grande variação em relação ao tipo de indumento. $A$ superfície do fruto, dentre as espécies observadas, varia de glabra a densamente setosa. Alguns tipos de indumento observados em Mimosa são peculiares a esse grupo e seguem relacionados abaixo.

Tipos de indumento:

1 - Setoso:

M. acerba (foto 7), M. elliptica, $M$. lanata, M. meticulosa, M. parvipinna, $M$. pigra (foto 12), M. polydactyla, $M$. pudica (foto 13), $M$. ramosissima, $M$. rigida, $M$. rupestris, $M$. sagotiana, $M$. sensitiva, $M$. schrankioides, $M$. velloziana.

2 - Glandular:

$M$. affinis, $M$. duckei, $M$. micracantha, M. paludosa, M. plathycarpa, $M$. pteridifolia, $M$. somnians (foto 14), $M$. spruceana (foto 15), M. ulbrichiana.

3 - Dendroide - (corresponde aos pêlos denominados por Burkart (1964:346) de "plumoso, coniferoides ou arbolito"):

M. daleoides, M. furfuracea (foto 16), $M$. incana.

4 - Estrigoso:

M. micropteris (foto 9), M. pachycarpa (foto 10).

5 - Estrelado:

M. scabrella (foto 17), M. schomburkii, M. taimbensis. 
A superfície de um único craspédio pode estar recoberta por mais de um tipo de indumento. Neste caso, na classificação acima, foi considerado o tipo que predomina no revestimento. Por outro lado, pode ocorrer, ainda, que apenas no replum os pêlos sejam evidenciados, como ocorre em M. pudica (foto 13), enquanto o epicarpo apresenta-se glabro ou subglabro. As demais espécies, não relacionadas, ou

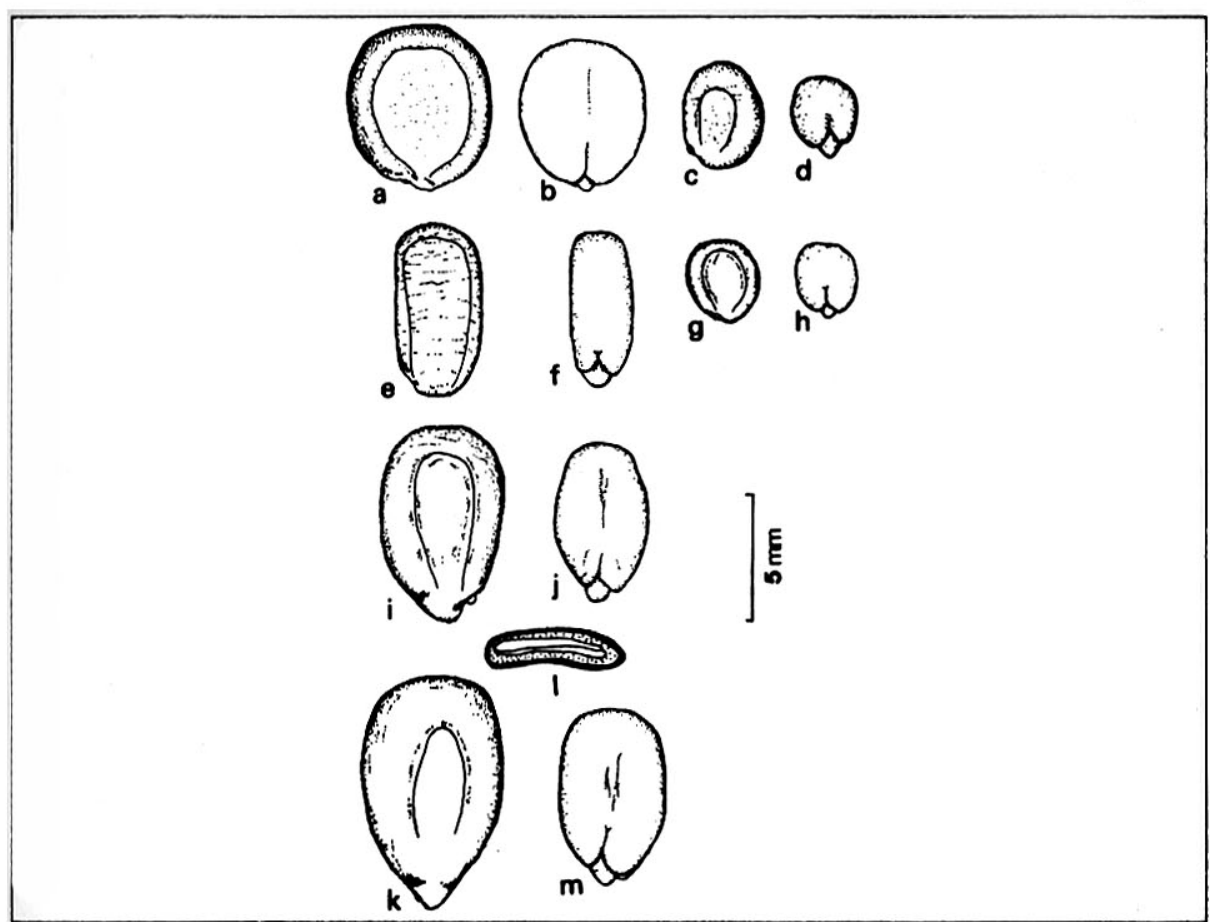

Figura 1

Sementes e Embriōes de Mimosa: a-b, M. claussenii; c-d, $M$. acerba; e-f, $M$. pigra; g-h, $M$. pudica; i-j, M. scabrella; k-m, M. plathycarpa.

possuem craspédios de glabros, como em M. caesalpiniaefolia (foto 18), a glabrescentes ou estes são revestidos por indumentos menos caracteristicos como hirsuto, piloso, híspidulo e pubérulo.

Além do indumento, observou-se que algumas espécies são facilmente distintas pelo aspecto aculeado do replum como em $M$. pseudo-obovata (foto 11) ou da parte central dos artículos como em $M$. modesta (foto 19) e $M$. ursina.

Em M. claussenii (foto 8) o craspédio é equinado.

As plúmulas, nas espécies de Mimosa, variam em relação ao grau de diferenciação dos segmentos em pinas, e os apêndices laterais, futuras estípulas, são muito ou pouco evidentes. Dentre as espécies examinadas, as plúmulas mais desenvolvidas foram evidenciadas em $M$. affinis (fig. 2d), M. claussenii, $M$. elliptica, $M$. lanata, $M$. paludosa, M. pigra (fig. 2c), M. scabrella, $M$. ulbrichiana e $M$. ursina. $\operatorname{Em} M$. affinis foram observadas, também, emergências glandulares, nas margens do eixo hipocótilo-radícula, na região próxima à plúmula e nos próprios segmentos que formam a plúmula. As demais espécies observadas, ou apresentam formas rudimentares como em $M$. hostilis (fig. 2a) ou intermediárias como em $M$. furfuracea (fig. 2b).

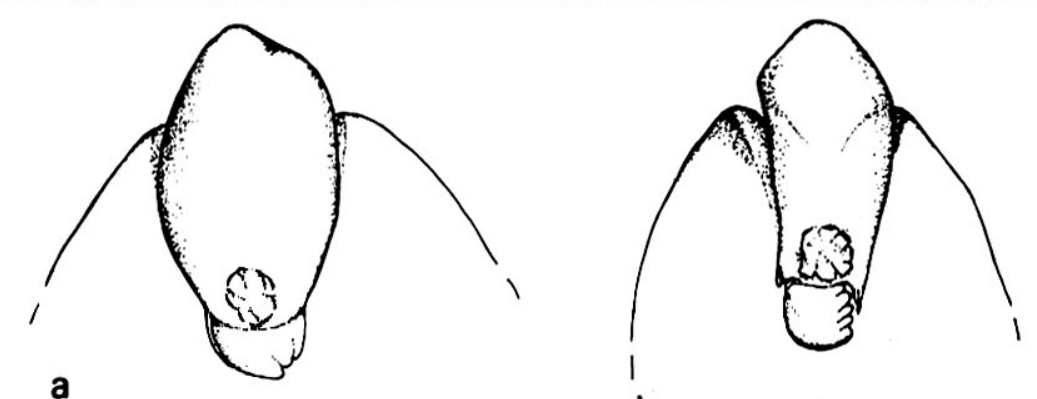

a

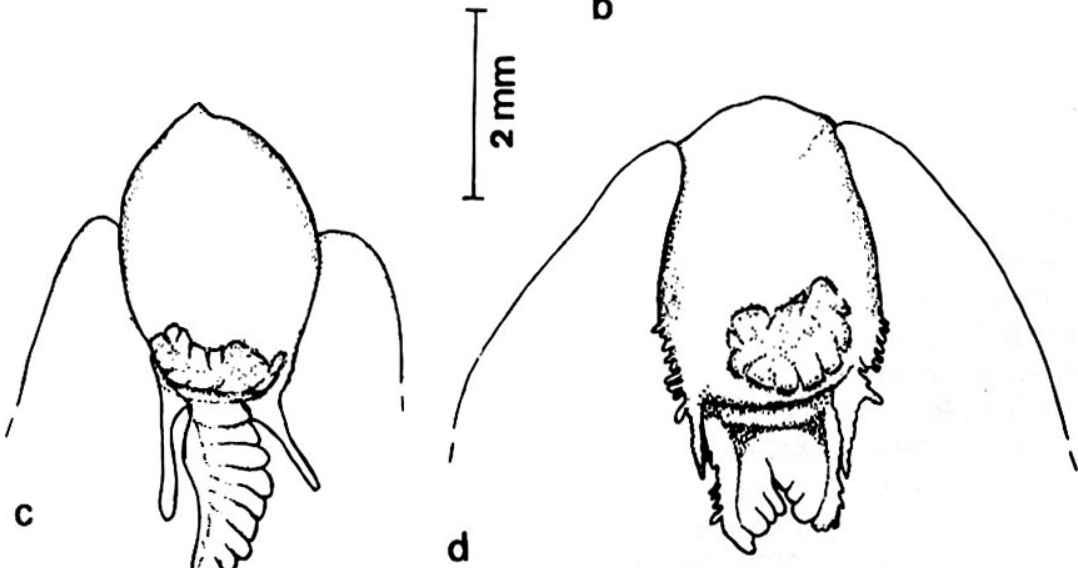

Figura 2

Plúmulas de Mimosa: a - M. hostilis; b - M. furfuracea; $c-M$. pigra; d - M. affinis. 
Todos os aspectos morfológicos, que foram abordados sobre os frutos e as plúmulas das espécies de Mimosa merecem um estudo mais detalhado, pois podem auxiliar o estudo taxonômico na caracterização de grupos de espécies ou até mesmo a nível de espécies.

Material Examinado

Mimosa acerba Benth. - BRASIL: São Paulo - Cotia, D. Constantino 140 (IV. 1941) RB; Itapetininga, J. I. de Lima s.n. (1.III.1951), carpoteca 3905, RB; Ibidem, idem s.n. (III.1945), carpoteca 3508, RB; Ibidem, idem s.n. (26.III.1945) RB.

Mimosa affinis Harms - BRASIL: Goiás $30 \mathrm{Km}$ Gama ao longo da estrada para o Rio Corumbá, B. Maguire et al. 57110 (16.X.1963) RB.

Mimosa bimucronata (DC.) O. Kuntze BRASIL: Rio de Janeiro - Caxias, próximo a Xerém, H. C. de Lima et $O$. Valverde 938 (30.IV.1979) RB. Santa Catarina - Brusque, H. P. Veloso 164 (9.IV.1951) RB. Mimosa caesalpiniaefolia Benth. - BRASIL: Maranhão - Caxias, A. Ducke s.n. (VI.1907) RB. Piauí - Estrada ParnaíbaChaval, Parnaíba, D. Sucre et al. 91995 (20.VI.1972) RB. Rio de Janeiro - Horto Florestal de Resende, J. G. Kuhlmann s.n. (29.XI.1930), carpoteca 2456, RB.

Mimosa casta L. - BRASIL: Pará - Belém, Baguary, Ilha dos Ouços, J. G. Kuh/ mann 31 (s.d.) RB.

Mimosa claussenii Benth. - BRASIL: Goiás - $\mathrm{S}$. João da Aliança, $A$. Mattos et al. 399 (18.VII.1963), carpoteca 4217, RB; s.I.: E. Ule s.n. (IX.1892) R.

Mimosa daleoides Benth. - BRASIL: Santa Catarina - Chapecó, $6-24 \mathrm{Km}$ oeste de Campo Erê, L. B. Smith et R. Klein 11549 (20.II.1957) R. (S/S).

Mimosa duckei Huber - BRASIL: Pará Serra da Velha Pobre, Almerim, A. Ducke s.n. (3.IX.1918) RB.

Mimosa elliptica Benth. - BRASIL: Rio de Janeiro - Restinga da Marambaia, D. Sucre et al. 1265 (30.XI.1966) RB; s.I., J. G. Kuhlmann s.n. (3.I.1923) RB.

Mimosa furfuracea Benth. - BRASIL: Paraná - Campo Largo, Rio Papagaios, G. Hatschbach 249 (5.III.1946) RB. Santa Catarina - Campo Alegre, Morro lquererim, L. B. Smith et R. Klein 7413 (s.d.) R.

Mimosa incana (Spreng.) Benth. - BRASIL: Rio Grande do Sul - Pelotas, J. C. Sacco 223 (10.XI.1954) RB, (S/S). Mimosa laevigata Benth. - BRASIL: Goiás - Brasília, rio Cabeça de Veado, E. Pereira 7380 (28.III.1963) RB. Mato Grosso -
Poconé, Fazenda Ipiranga, A. Allem et $G$. Vieira 1024 (26.VII.1977) RB.

Mimosa lanata Benth. - BRASIL: São Paulo - Vila Emas, Brade 12854 (XII. 1933) RB.

Mimosa meticulosa Mart. - BRASIL: Paraná - Arapoti, L. B. Smith et al. 14708 (17.I.1965) R.

Mimosa micracantha Benth. - BRASIL: Pará - Itaituba, Rio Tapajós. A. Ducke s.n. (23.V.1923) RB; Serra de Santarém, idem s.n. (2.IX.1923) RB.

Mimosa micropteris Benth. - BRASIL: Paraná - Sengés. Serra do Mocambo, G. Hatschbach 27160 (8.X.1971) HB; Vila Velha, E. Pereira 8293 (14.I.1964) RB; Ibidem, E. Fromm et al. 357 (18.X.1961) R. Mimosa modesta Mart. - BRASIL: Bahia - Serra do Açuruá, R. M. Harley et al. 18900 (1.IV.1977) RB, (S/S).

Mimosa myriadena Benth. -- BRASIL: Amazonas - Rio Negro, J. G. Kuhlmann 1032 (31.XII.1923) RB.

Mimosa pachycarpa Benth. - BRASIL: Minas Gerais - Curvelo estrada para Diamantina, B. Maguire et al. 44778 (23.XII.1959) RB, (S/S).

Mimosa paludosa Benth. - BRASIL: Bahia - Serra do Rio das Contas, R. M. Harleyet al. 20047 (27.III.1977) RB. Minas Gerais - Barbacena, E. Pereira 7546 (5.IV.1963) RB.

Mimosa parvipinna Benth. - ARGENTINA: s.I., Burkart 15444 (17.XI.1945) RB. Mimosa pigra L. - BRASIL: Ceará - s.I., Fr. Allemão et M. Cysneiros 515 (s.d.) R. Bahia - Serra do Rio das Contas, R. $M$. Harley 19860 (14.XII.1978) RB. Rio de Janeiro - Cultivada no Jardim Botânico, $J$. G. Kuhlmann s.n. (s.d.), carpoteca 2881 , RB. Mato Grosso - Lagoa Gahyba, J. C. Diogo 285 (s.d.) R; Margem do Rio Araguaia, J. M. de Oliveira 3056 (5.XII.1977) RB; Santa Terezinha, C. T. Falcão 5136 (27.XI.1977) RB.

Mimosa platycarpa Ducke - BRASIL: Ceará - Fortaleza, beira da rodagem para Maranguape, A. Ducke 2542 (23.III.1956) RB; Fortaleza, A. G. Fernandes 2107 (s.d.) RB.

Mimosa polydactyla Humb. et Bompl. ex Willd. - BRASIL: Pará - Belém, A. Ducke s.n. (31.III.1915) RB; Pernambuco - Recife, Dois Irmãos, D. Vasconcellos s.n. (XI.1936) RB.

Mimosa pseudo-obovata Taub. - BRASIL: Pernambuco - Usina Mussurepe, estrada aldeia, borda da mata, Ducke et A. Lima 23 (20.XI.1951) R. Rio de Janeiro, Barra da Tijuca, J. G. Kuhlmann 6217 (23.I.1945) $\mathrm{RB}$; (S/S) Recreio dos Bandeirantes, Jaca- repaguá, A. P. Duarte 4097 (1952) RB; (S/S) RB; (S/S). Ibidem, Palcios et al. 4066 (9.I.1949) R. Santa Catarina - Florianópolis, Bom Abrigo, E. Santos et J. C. Sacco 1822 (6.II.1964) HB. (S/S).

Mimosa pteridifolia Benth. - BRASIL: Bahia - Serra do Açuruá, 1,5 Km. São Inácio, Estrada Gentio do Ouro, R. M. Harley et al. 1900 (24.II.1977) RB.

Mimosa pudica L. - BRASIL: Rio de Janeiro - Aterro, Aeroporto Santos Dumont, Jurandir s.n. (1964) RB.

Mimosa ramosissima Benth. - BRASIL: Santa Catarina - Campo Erê, $8 \mathrm{Km}$ a oeste, L. B. Smith et R. M. Klein 13778 (7.XII.1964) R; Lajes, L. B. Smith et $R$. Klein 8064 (2.XII.1956) R.

Mimosa rigida Benth. - BRASIL: Minas Gerais - Ouro Brando, P. C. Porto 1209 (26.XI.1922) RB; Ouro Preto, Três Moinhos, H. C. de Lima etal. 1274 (5.VIII.1980) RB; São Tomé das Letras, Baependi, Brade et Apparício 20487 (14.VII.1950) RB.

Mimosa rupestris Benth. - BRASIL: Minas Gerais - Serra do Ouro Branco, E. Pereira et G. Pabst 2950 (s.d.) RB.

Mimosa sagotiana Benth. - BRASIL: Pará - Óbidos, A. Ducke s.n. (15.ll.1918) RB. Mimosa scabrel/a Benth. - BRASIL: São Paulo - Cunha, Reserva Estadual de Cunha na beira do Rio Bonito, H. C. de Lima 1125 (s.d.) RB. Santa Catarina - Bom Retiro, P. R. Reitz 3603 (XII. 1949) R. Mimosa schomburgkii Benth. - BRASIL: Amazonas - Boa Vista, Rio Branco, $A$. Ducke s.n. (28.VI. 1937) RB. Pará - Cultivado em Belém, A. Ducke s.n. (IX. 1956) RB.

Mimosa schrankioides Benth. - BRASIL: Pará - almerim, boca do Aramum, $A$. Ducke s.n. (5.VII.1919) RB.

Mimosa sensitiva L. - BRASIL: Pará Belém, A. Ducke s.n. (7.XI.1922) RB; Piauí - Parnaíba, Lagoa Portinho, D. Araújo et al. 452 (3.X.1973) RB; Sete Cidades, Parque Nacional Boqueirão, G.M. Barroso 40 (13.IX.1977) RB. Ceará - Entre Barbalha e Crato, A. Castellanos s.n. (21.VII.1964) HB; Serra do Baturité, Sítio B. Inácio de Azevedo, J. Eugenio 595 (VII.1937) RB.

Mimosa somnians Humb. et Blomp ex Willd. - BRASIL: Paraíba - João Pessoa, J. I. A. Falcão et al. 1102 (15.IX.1954) RB. ARGENTINA: s.l., Burkart 15283 (12.II.1945) RB.

Mimosa spruceana Benth. - BRASIL: Amazonas - Manaus, Cachoeira Grande, J. G. Kuhlmann 164 (23.VIII.1923) RB. Mimosa ulbrichiana Harms. - BRASIL: Bahia - Serra do Açuruá, R. M. Harley et al. 18992 (24.II. 1977) RB. 
Mimosa ursina Mart. - BRASIL: Bahia Serra do Sincorá, 15-20 Km para Andaraí estrada Itaeté-Mucugê, R. M. Harley et al. 18633 (17.II.1977) RB.

Mimosa velloziana Mart. - BRASIL: Bahia - Sales, J. M. Brazão 85 (1.IX.1978) RB. Rio de Janeiro - Campo Grande, Serra do Mendanha, H. C. de Lima 98 (6.VII.1977) RB. Goiás - Parque Nacional de Brasília, E. P. Heringer 9675 (20.V.1964) RB.

\section{2 - Schrankia Willdenow}

Willdenow, Sp. PI. 4(2):888, 1041. 1806.

Foto: 20 ; Fig.: 3

Craspédio deiscente segmentado com $7,5-11,5 \mathrm{~cm}$ de comprimento $\times 0,2 \mathrm{~cm}$ de largura, linear, tetragonal, subcilíndrico, reto, séssil, cartáceo, pardacento, opaco, esparsamente aculeado, glabro; replum expandido, aculeado, reto.

Semente com 0,4-0,6 cm de comprimento $\times 0,2-0,3 \mathrm{~cm}$ de largura, oblonga, com faces convexas, não alada, longitudi- nal, com endosperma; testa de consistência rígido-membranácea, nigrescente, nítida, com pleurograma apical-basal com braços afastados.

Embrião com cotilédones de 0,4-0,5 de comprimento $\times 0,2-0,3 \mathrm{~cm}$ de largura, cordado-oblongos, plano-convexos; eixo hipocótilo-radícula com $0,2 \mathrm{~cm}$ de comprimento, emergente; plúmula diferenciada em pinas, com apêndices laterais pronunciados.

O craspédio de Schrankia, por sua forma tetragonal e por apresentar o replum tão ou mais largo que as paredes do fruto, torna-se distinto dos craspédios de Mimosa p.p. As "valvas" do fruto de Schrankia não se apresentam septadas internamente formando artículos, e nem são totalmente indivisas como nos craspédios de algumas espécies de Mimosa. Tais estruturas separam-se do replum através de fraturas que ocorrem em espaços mais ou menos regulares, libertando, assim, as sementes.

A plúmula de Schrankia (fig. 3d) é muito característica por sua evidente diferencia- ção em pinas e pelos apêndices laterais, futuras estípulas, muito pronunciados.

\section{Material Examinado}

Schrankia leptocarpa DC. - BRASIL: Pará - Belém, Souza, W. A. Archer 7532 (31.VII.1942) IAN. Piaui - Lagoa do Portinho, D. Sucre et al. 10261 (3.X.1973) RB. Ceará - Campo de fruticultura do Cariri, Crato, A. Duarte et Ivone 1298 (5.VIII.1948) RB; Serra do Baturité, Sítio B. Inácio de Azevedo, J. Eugênio 594 (IX.1937) RB; s.I. Fr. Allemão s.n. (s.d.) R. Rio Grande do Norte - Arredores de S. José de Mipibu, L. Emygdio 1698 (3.VII.1959) R. Pernambuco - Recife, Curados, J.I.A. Falcão etal. 764 (24.VIII.1954) RB.

3 - Entada Adanson

Adanson, Fam. PI. 2:318. 1763

Foto: 21 ; Fig. 4

Craspédio indeiscente articulado com $31,0-39,0 \mathrm{~cm}$ de comprimento $\times 5,0$ -
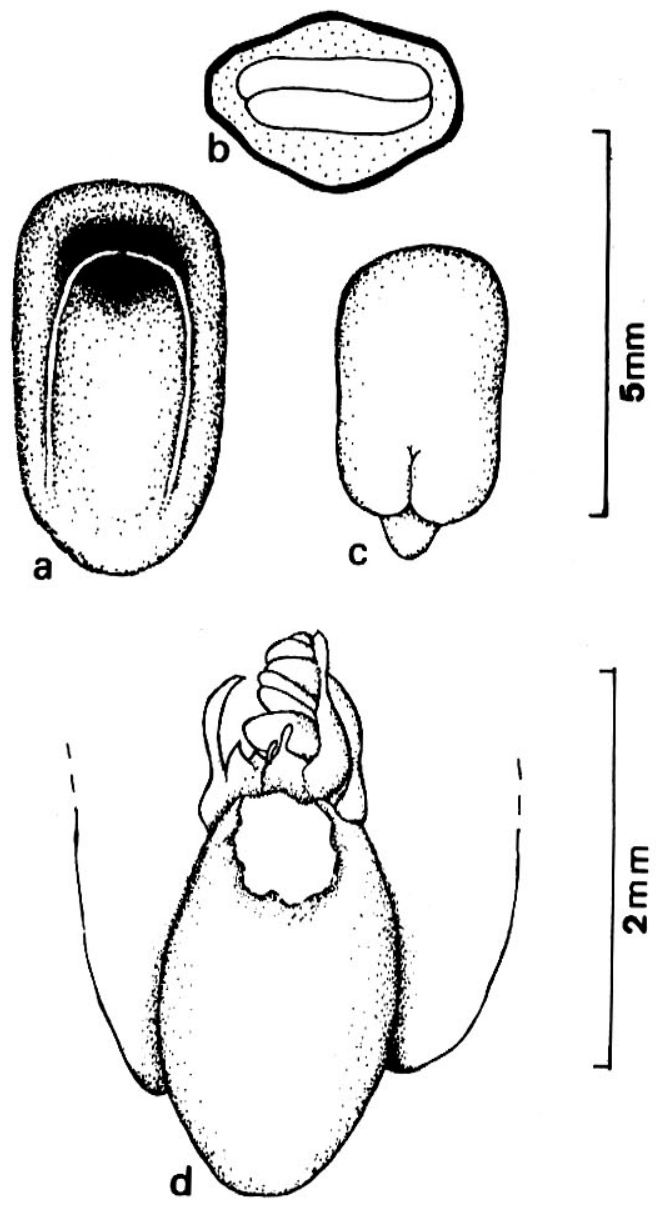

Figura 3

Schrankia leptocarpa: a - semente; b - secção transversal; c - embrião; d-plúmula.

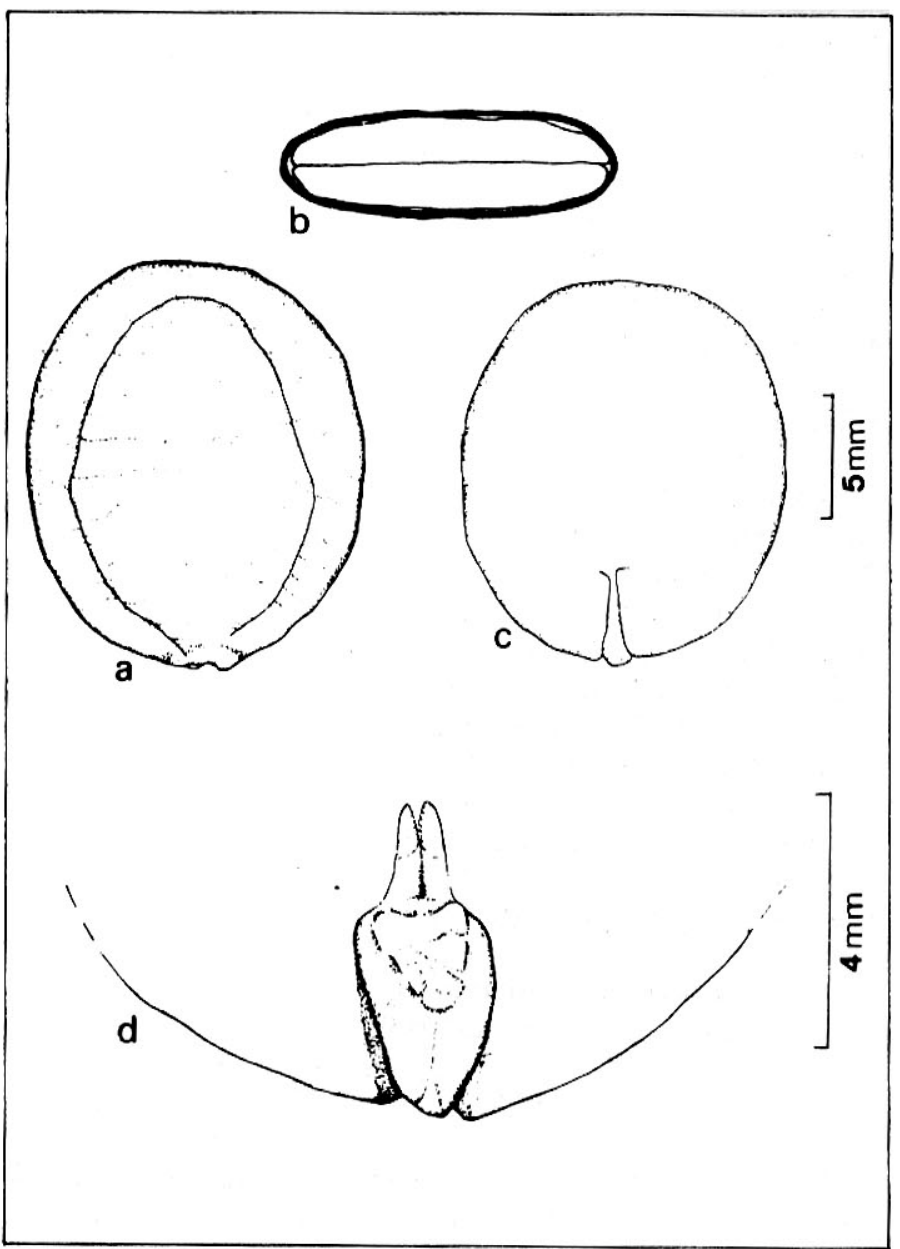

Figura 4

Entada polystachya: a - semente; b - secção transversal; c - embrião; d - plúmula. 
$7,0 \mathrm{~cm}$ de largura, oblongo, plano-compresso, subfalcado, estipitado $(3,0-4,0 \mathrm{~cm})$, epicarpo cartáceo de pardacento a nigrescente, nítido, venoso, glabro; endocarpo segmentado; artículos monospérmicos sub-retangulares, com a região seminífera de consistência espanjosa, densamente reticulada, e bordos cartáceos ou artículos cartáceos; replum de sub-lenhoso a lenhoso, levemente constricto.

Semente com $1,7-2,0 \mathrm{~cm}$ de comprimento $\times 1,3-1,5 \mathrm{~cm}$ de largura, suborbicular, com faces convexas, não alada, transversal, sem endosperma; testa de consistência rígida, castanho-avermelhada, nítida, com pleurograma apical-basal com braços aproximados.

Embrião com cotilédones de 1,4$1,6 \mathrm{~cm}$ de comprimento $\times 1,3 \mathrm{~cm}$ de largura, cordado-suborbiculares, plano-convexos; eixo hipocótilo-radícula com $0,4 \mathrm{~cm}$ de comprimento, emergente; plúmula sem nítida diferenciação em pinas.

$O$ gênero, com a grande maioria de suas espécies africanas, está representado no Brasil por $E$. polyphylla e E. polystachya, subordinadas por Brenan (1966) à seção Entadopsis. O craspédio, articulado $e$ indeiscente, diferencia-se dos craspédios deste mesmo tipo encontrado em certas espécies de Mimosa, por suas dimensões bem maiores e pela disjunção entre o epicarpo e o endocarpo.

\section{Material Examinado}

Entada polyphylla Benth. - BRASIL: Amazonas - Manaus, Ponta Negra, W. Rodrigues 8656 (16.XII.1969) RB (S/S).

Entada polystachya (L.) DC. - BRASIL: Roraima - Canta Galo, Rio Mucajaí entre Pratinha e Rio Apiaú, G. T. Prance et al. 4003 (22.1.1967) R. Rondonia, Cachoeira Misericórdia, Rio Madeira no Riberão, G. T. Prance et al. 6726 (2.VIII.1968) R. Pará, Marabá, G. A. Black 49-7937 (21.VI.1949) IAN. Mato Grosso, Estrada de ferro M. Momoré, J. G. Kuhlmann s.n. (22.IX.1923), carpoteca 394, RB; Guajará-Mirim, J. G. Kuhlmann 442 (12.IX.1923) RB.

\section{4 - Stryphnodendron Martius}

Martius, Herb. FI. Bras. 20(2) Beibl. 117.1837.

Fotos: 22-24; Fig. 5a-f.

Legume carnoso ou mais raramente folículo, com $6,0-16,0 \mathrm{~cm}$ de comprimento $\times 1,0-2,5 \mathrm{~cm}$ de largura, oblongo, linearoblongo, subcilíndrico ou plano-compresso, reto ou falcado, séssil ou subséssil,

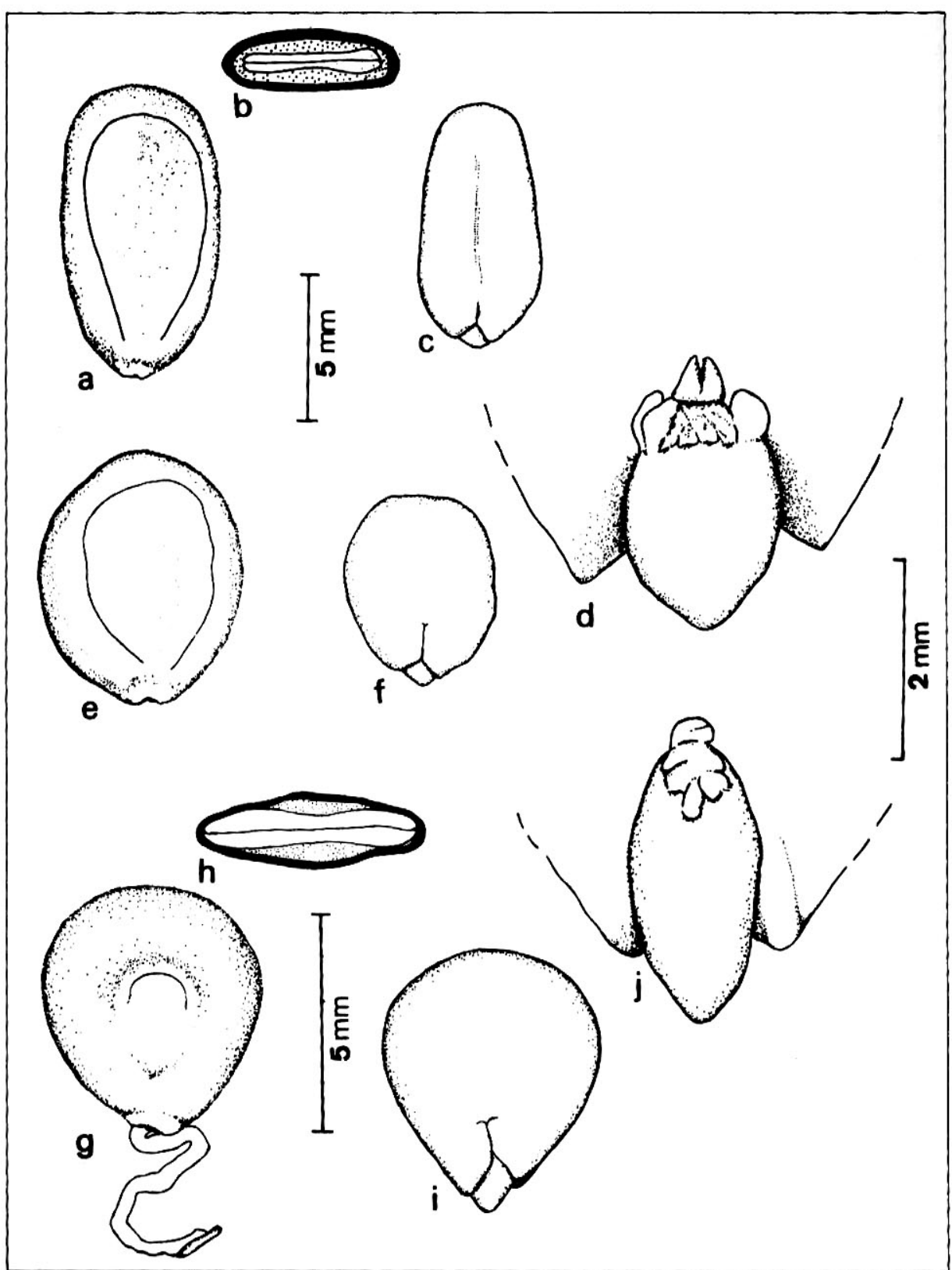

Figura 5

Stryphnodendron adstringens: a - semente; b - secção transversal; c - embriåo; d - plúmula; Stryphno. dendron coriaceum: a - semente; $f$ - embrião; Goldmania paraquensis: $g$ - semente; $\mathrm{h}$ - secção transversal; i - embriäo; j - plúmula.

crasso, de castanho-avermelhado a nigrescente, nítido ou opaco, rugoso, glabro ou com pêlos curtos, caducos, de aspecto pulverulento; margens não espessadas, retas ou sinuosas.

Semente com 0,7-1,2 cm de comprimento $\times 0,4-0,8 \mathrm{~cm}$ de largura, obovóide, oblonga, oblonga-obovóide ou suborbicular, com faces convexas, não alada, transversal ou oblíqua, com endosperma; testa de consistência rígida, de pardacenta a castanho-escura, opaca, com pleurograma apical-basal com braços de afastados a semi-unidos.
Embrião com cotilédones de 0,6 $1,0 \mathrm{~cm}$ de comprimento $\times 0,3-0,8 \mathrm{~cm}$ de largura, de cordado-orbiculares a cordadooblongos, plano-convexos; eixo hipocótilo-radícula com $0,1-0,3 \mathrm{~cm}$ de comprimento, emergente; plúmula sem nítida diferenciação em pinas.

Entre as espécies examinadas do gênero Stryphnodendron, foram evidenciados dois tipos de frutos:

folículo - com septos muito tênues entre as sementes. Observado apenas em S. gracile (foto 24);

legume carnoso (fotos 22-23) - com 
septos espessados, permanecendo as sementes isoladas umas das outras, $e$, às vezes, encerradas em verdadeiras cavidades como em $S$. coriaceum (foto 23). Este tipo de fruto foi encontrado na maioria das espécies examinadas.

As sementes caracterizam-se pela testa muito rígida, marcada pelo pleurograma apical-basal (fig. 5 a e $5 \mathrm{e}$ ).

\section{Material Examinado}

Stryphnodendron adstringens (Mart.) Coville - BRASIL: Minas Gerais - Carmo da Cachoeira, J. C. C. Ururahy 1 (23.V. 1978) RB. Goiás - Estrada Luziania-Vianópolis, H. Magnago 235 (14.III.1978) RB.

Stryphnodendron coriaceum Benth. BRASIL: maranhão - Chapadinha, D. Sucre et J. F. da Silva 9424 (28.VI.1972) RB. Piauí - Sete Cidades, Boqueirão, G. M. Barroso 103 (13.IX.1977) RB.

Stryphnodendron gracile Her. et Rizz. BRASIL: Minas Gerais - Km 113 ao longo da rod. Lagoa Santa-Conceição do Mato Dentro, Diamantina, Jaboticatubas, $A$. $B$. Jolyetal. 1534 (15.IV.1972) UEC; Serra do Cipó, Santana do Riacho, G. Martinelli 254 (10.V.1974) RB.

Stryphnodendron obovatum Benth. BRASIL: Paraná - Fazenda Lagoa, Cianorte, G. Hatschbach 21565 (19.V.1969) UEC. Mato Grosso - Rio Araguaia, Xavantina, $H$. S.Irwinetal. 16700 (s.d.) HB; Rio Pardo, G. Martinelli 408 (13.VI.1974) RB.

Stryphnodendron polyphyllum Mart. BRASIL: Minas Gerais - Km 416 da BR-3 entre Juiz de Fora e Santos Dumont, $A$. $P$. Duarte et $A$. Mattos 8228 (29.VII.1964) HB; Reserva Florestal do Rio Doce, mata Lagoa do Anibal, D. Sucre et al. 10098 (29.VIII.1973) RB.

\section{5-Goldmania Rose ex Micheli}

Rose ex Micheli, Mém. Soc. Phys. Hist. Nat. Genève 34(3):274. 1903.

Foto: 25 ; Fig. $5 \mathrm{~g}$-j

Folículo com 6,0-6,5 cm de comprimento $\times 1,0 \mathrm{~cm}$ de largura, oblongo, planocompresso, subfalcado, subséssil, coriáceo, castanho, opaco, liso, com pêlos curtos caducos, de aspecto pulverulento; margens não espessadas retas ou sinuosas.

Semente com 0,6-0,7 cm de comprimento $\times$ 0,5-0,6 cm de largura, obovóide, comfaces convexas, não alada, transversal a levemente oblíqua, com endosperma; testa de consistência rígida, pálido-acinzentada, opaca, com pleurograma mediano com braços muito afastados.
Embrião com cotilédones de $0,5 \mathrm{~cm}$ de comprimento $\times 0.4 \mathrm{~cm}$ de largura, cordadoobovóides, plano-convexos; eixo hipocótilo-radícula com $0,2 \mathrm{~cm}$ de comprimento, emergente; plúmula sem nítida diferenciaçăo em pinas.

A única espécie brasileira, G. paraguensis, é diferenciada das espécies de outros gêneros com frutos foliculares, pelo fato do folículo ser bem menor, expondo as sementes pálido-acinzentadas, características desta espécie.

\section{Material Examinado}

Goldmania paraguensis (Benth.) Brenan -
BRASIL: Mato Grosso - Corumbá, à margem direita da Baía de Tomengo próximo a estrada Brasil-Bolívia, C.A. Conceiçáo 559 (30.XI.1979) RB; Fazenda Pallatz, $P . P$. Furtado s.n. (3.X.1980) RB.

\section{6 - Pseudopiptadenia Rauschert Rauschert, Taxon 31:559.1982 Foto: 26; Fig. 6a-d}

Folículo com $13,0-28,0 \mathrm{~cm}$ de comprimento $\times 1,0-2,0 \mathrm{~cm}$ de largura, moniliforme, plano-compresso, contorcido, estipitado $(1,0 \mathrm{~cm})$, de cartáceo a coriáceo, de acinzentado a pardacento, opaco, venoso,

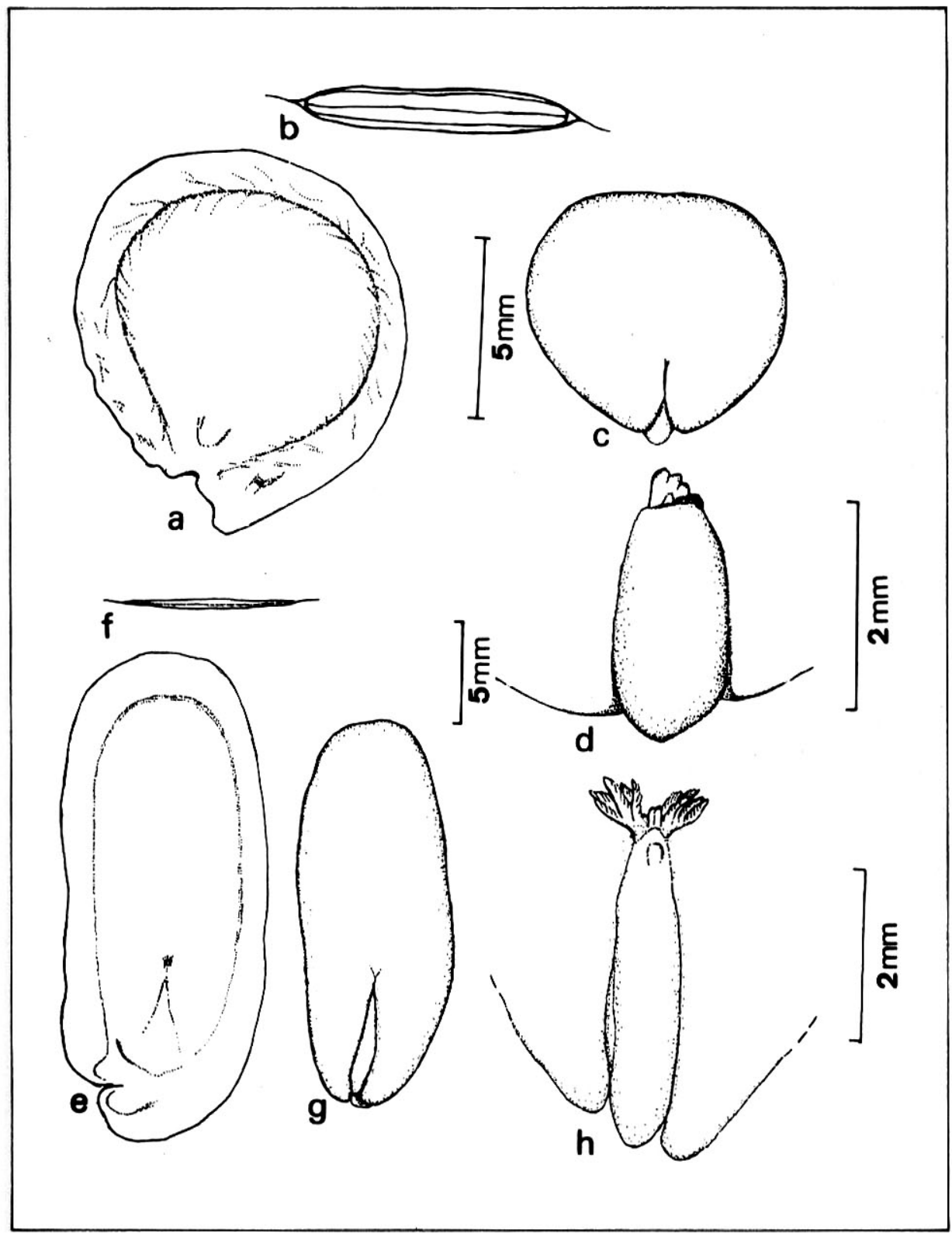

Figura 6

Pseudopiptadenia leptostachya: a - semente alada; $\mathrm{b}$ - secçăo transversal; $\mathrm{c}$ - embrião; $\mathrm{d}$ - plúmula: Newtonia nitida; $\mathrm{e}$ - semente alada; $\mathrm{f}$ - secçăo transversal; $\mathrm{g}$ - embriåo; $\mathrm{h}$ - plúmula. 
lepidoto, glabro; margens levemente espessadas e muito constrictas.

Semente com 0,9-1,6 cm de comprimento $\times$ 0,9-1,8 cm de largura, orbicular, suborbicular ou transverso-elíptica, com faces planas, clada, longitudinal, com camada muito escassa de endosperma; testa de consistência membranácea a rígidomembranácea, pardacenta, nítida, sem pleurograma.

Embrião com cotilédones de 0,6$1,2 \mathrm{~cm}$ de comprimento $\times 0,6-1,6 \mathrm{~cm}$ de largura, cordado-orbiculares, cordadosuborbiculares, ou cordado-transversoelípticos, planos; eixo hipocótilo-radícula com 0,3-0,5 cm de comprimento, emergente; plúmula sem nítida diferenciação em pinas, com estruturas globosas adjacentes.

Brenan (1955) criou o gênero $M o$ noschisma e a este subordinou as espécies, anteriormente pertencentes a Piptadenia sect. Pityrocarpa, $P$. leptostachya e $P$. inaequalis as quais possuem frutos do tipo folículo e sementes aladas. Segundo Rauschert (1982) o nome Monoschisma já havia sido dado por Duby (1868) para um gênero de Musci. Assim sendo Rauschert, 1.c., propôs o nome Pseudopiptadenia em substituição a Monoschisma.

Brenan (1955) considerou o gênero em questão, principalmente em relaçăo às características do fruto e da semente, muito próximo de Anadenanthera. Considerando esses mesmos caracteres, parece que as espécies de Pseudopiptadenia apresentam maior afinidade, ainda, com as do gênero Newtonia, devido a ocorrencia do mesmo tipo de fruto e pela presença da ala e ausência de pleurograma nas sementes (fig. 6a). O folículo de Pseudopiptadenia (foto 26) diferencia-se dos de Anadenanthera (fotos 28 e 29) e Newtonia (foto 27), por seu aspecto moniliforme. A plúmula de Pseudopiptadenia (fig. 6d), não diferenciada em pinas, distingue as espécies deste gênero, dos dois outros afins.

As estruturas globosas adjacentes à plúmula, na fase do processo de germinaçăo, na qual os cotilédones apresentam-se expandidos, aglomeram-se na base do epicótilo. À medida que o epicótilo se prolonga e os primeiros eófilos se desenvolvem, tais estruturas parecem regredir. Pretendese desenvolver estudos mais detalhados sobre a composição e a função de tais formações, obsenvadas apenas nas plúmulas das espécies deste gênero.

\section{Material Examinado}

Pseudopiptadenia inaequalis (Benth.) Rauschert - BRASIL: Rio de Janeiro Estrada da Vista Chinesa, J. G. Kuhlmann s.n. (2.IV.1929), carpoteca 2435, RB; Petrópolis, Serra da Estrela, Raiz da Serra Estrada Velha - Estrada das Pedras, $L$. Mautone et al. 288 (5.IX.1977) RB; Serra do Arapucaia, Pessoal do Horto s.n. (14.VII.1927), carpoteca 2567, RB.

Pseudopiptadenia leptostachya (Benth.) Rauschert - BRASIL: Rio de Janeiro Parque Nacional da Tijuca, próximo da Vista Chinesa, H. C. de Lima et al. 1625 (3.VI.1981) RB; Tijuca, A. C. Brade s.n. (s.d.) R.

\section{7 - Newtonia Baillon}

Baillon, Bull. Soc. Linn. Paris 1: 721. 1888.

Foto: 27 ; Fig. $6 \mathrm{e}-\mathrm{h}$

Folículo com 15,0-35,0 cm de comprimento $\times 1,5-4,0 \mathrm{~cm}$ de largura, de linearoblongo a amplamente oblongo, planocompresso, reto ou falcado ou, raramente, torcido, subséssil ou estipitado 10,5 $1,0 \mathrm{~cm})$, de subcoriáceo a sublenhoso, de castanho a nigrescente, nítido, venoso, glabro; margens espessadas, sinuosas ou levemente constrictas.

Semente com 1,5-5,2 cm de comprimento $\times 0,8-2,0 \mathrm{~cm}$ de largura, oblonga, suboblonga ou raramente, transversooblonga, com faces planas, amplamente alada, longitudinal, sem endosperma; testa de consistência membranácea, pardacenta, opaca sem pleurograma.

Embrião com cotilédones de 1,3$2,5 \mathrm{~cm}$ de comprimento $\times 0,6-1,8 \mathrm{~cm}$ de largura, de cordado-oblongos a raramente transverso-oblongos, planos; eixo hipocótilo-radícula com $0,5-0,6 \mathrm{~cm}$ de comprimento, emergente ou não; plúmula diferenciada em pinas.

Brenan (1955) transferiu as espécies de Piptadenia (P. nitida, P. psilostachya e $P$. suaveolens), com fruto do tipo folículo e semente alada, para o gênero Newtonia que até então só constava de espécies africanas. Burkart (1979), após reconhecer para o gênero Newtonia mais duas espécies, N. glaziovii (foto 27) e N. contorta, subordinou as espécies brasileiras deste gênero a sect. Neonewtonia.

As espécies de Newtonia diferenciamse das dos gêneros afins Anadenanthera e Pseudopiptadenia, principalmente, pelas sementes amplamente aladas (fig. 6e) e através da plúmula diferenciada em seg. mentos alongados (fig. 6h).

\section{Material Examinado}

Newtonia contorta (DC.) Burkart - BRA. SIL: Bahia - Iramaia, P. Vaillant 15 (20.VI.1978) RB. Minas Gerais - Estaçăo Experimental Cel. Pacheco, E. P. Heringer s.n. (13.X.1946) R; Mata da Lagoa do Anibal, Resenva Florestal do Rio Doce, $D$. Sucre et al. 10105 (29.VIII.1973) RB. Rio de Janeiro - Estrada Vista Chinesa Km. 6, C. Angeli 186 (20.X.1960) RB; Horto Flo. restal, J. G. Kuh/mann s.n. (10.XI.1927), carpoteca 2460 , RB.

Newtonia glaziovii (Harms) Burkart - BRA. SIL: Minas Gerais - Jequitibá, E. P. Heringer s.n. (IV.1958) carpoteca 2437, RB. Rio de Janeiro - Horto Florestal, J. G. Kuhl. man s.n. (1928), carpoteca 2431, RB; Serra da Estrela, Glaziou 8440 (s.d.) R. São Paulo - Parque da Av. Paulista, A. Gehrt s.n. (21.X.1935) UEC.

Newtonia nitida (Benth.) Brenan - BRA. SIL: Ignorado, Caminho do Macaco, Saldanha et Glaziou 4953 (3.X.1878) R. Rio de Janeiro - Matas do Horto Florestal, J. G. Kuh/mann s.n. (1927), carpoteca 2440 , RB; Mata do Rumo (Reserva Florestal do Jardim Botânico), D. Sucre 4471 et $P$. I. Braga 1348 (19.I.1969) RB; Vista Chinesa, A. P. Duarte 5782 (X. 1961) RB.

Newtonia suaveolens (Miq.) Brenan BRASIL: Pará - Belém, beira do Rio Guamá, Tucunduba, G. A. Black 52-14146 (24.I.1952) R; s.l., R. L. Fróes et Murçe Pires 24136 (s.d.) RB.

\section{8 - Anadenanthera Spegazzini Spegazzini, Physis 6:313. 1923. Fotos: 28-29; Fig. 7}

Folículo com 10,0-30,0 cm de compri. mento $\times 1,0-2,5 \mathrm{~cm}$ de largura, linearoblongo, plano-compresso, reto ou subfal. cado, estipitado $(1,0-2,0 \mathrm{~cm})$, coriáceo, de castanho a nigrescente, nítido, venoso, liso ou verrucoso, glabro; margens espes. sadas, sinuosas ou, mais raramente, cons trictas.

Semente com 0,8-1,6 cm de compri. mento $\times 1,0-2,0 \mathrm{~cm}$ de largura, orbicular, suborbicular ou, mais raramente, transver. so-elíptica, com faces planas, raramente alada, transversal ou longitudinal sem en. dosperma; testa de consistência membra. nácea, castanha, nítida, com pleurograma mediano com braços afastados, ou, raramente, sem pleurograma.

Embrião com cotilédones de 0,8 - 
$1,7 \mathrm{~cm}$ de comprimento $\times 0,6-2,0 \mathrm{~cm}$ de largura, cordado-orbiculares, cordado-suborbiculares ou cordado-subtransversoelípticos, plano-convexos; eixo hipocótiloradícula com 0,3 a $0,5 \mathrm{~cm}$ de comprimento, geralmente não emergente; plúmula diferenciada em pinas.

Os caracteres utilizados por Brenan (1955) para restabelecer o gênero Anadenanthera são basicamente o fruto do tipo folículo e as sementes não aladas. As espécies deste gênero foram subordinadas, anteriormente, por Bentham (1841), ao gênero Piptadenia (sect. Niopa).

Ao examinar-se o material, observouse que além das características estabelecidas por Brenan, a plúmula, que se apresenta com aspecto morfológico constante, é peculiar às espécies deste gênero. Mesmo em $A$. colubrina onde o fruto, com as margens constrictas (foto 28), e as sementes, com ala estreita e sem pleurograma (fig. 7a), assemelham-se aos frutos e se- mentes de Pseudopiptadenia, tal espécie é facilmente identificada através da plúmula diferenciada em pinas (fig. $7 \mathrm{~g}$ ).

\section{Material Examinado}

Anadenanthera colubrina (Vell.) Brenan BRASIL: Minas Gerais - Estação Experimental Cel. Pacheco. V. Gomes 2573 (28.I.1956) RB. Rio de Janeiro - Baía de Sepetiba, D. Sucre s.n. (25.VIII.1968), carpoteca 4470, RB; Parque Nacional da Tijuca, Estrada para Furnas, H. C. de Lima 1092 (10.IX.1979) RB; Restinga de Jacarepaguá, lado oeste da Pedra de Itauna, $D$. Sucre 6083 (30.XI.1969) RB.

Anadenanthera macrocarpa (Benth.) Brenan - BRASIL: Piauí - Pedro II, Serra dos Motões, D. Sucre et J. F. da Silva 9305 (24.VI.1972) RB. Pernambuco - Ibimirim, Falcão et al. 1033 (12.IX.1954), carpoteca 408, RB. Bahia - Estrada para Tanhaçú, J. E. M. Brazão 117 (8.VIII.1979) RB. Mato
Grosso - Linha do Rosário, J. G. Kuh/mann 402 (X. 1914) R.

Anadenanthera peregrina (L.) Speg. BRASIL: Rio de Janeiro - Horto Botânico do Museu Nacional, A. M. Mattos 1906 (s.d.) R; Horto Florestal, J. G. Kuh/mann s.n. (1927), carpoteca 2441, RB. Minas Gerais - Zona da Mata, C. T. Rizzini s.n. (10.XI.1961), carpoteca 2841, RB. São Paulo - Bastos, G. A. Black 11706 (29.I.1951) R; Campinas - Parque Taquaral, H. F. Leitão Filho et al. 8342 (5.VII.1978) UEC; Orlândia, M. M. Santos 02 (31.V.1979) RB; Mato Grosso - Cuiabá, A. Malme 3176 (26.IV.1903) R.

\section{9 - Plathymenia Bentham}

Bentham In Hooker's Journ. Bot. 2:134. 1840; 4:333. 1841.

Foto: 30 ; Fig. 8

Criptolomento com $12,0-25,5 \mathrm{~cm}$ de comprimento $\times 2,0-5,0 \mathrm{~cm}$ de largura,

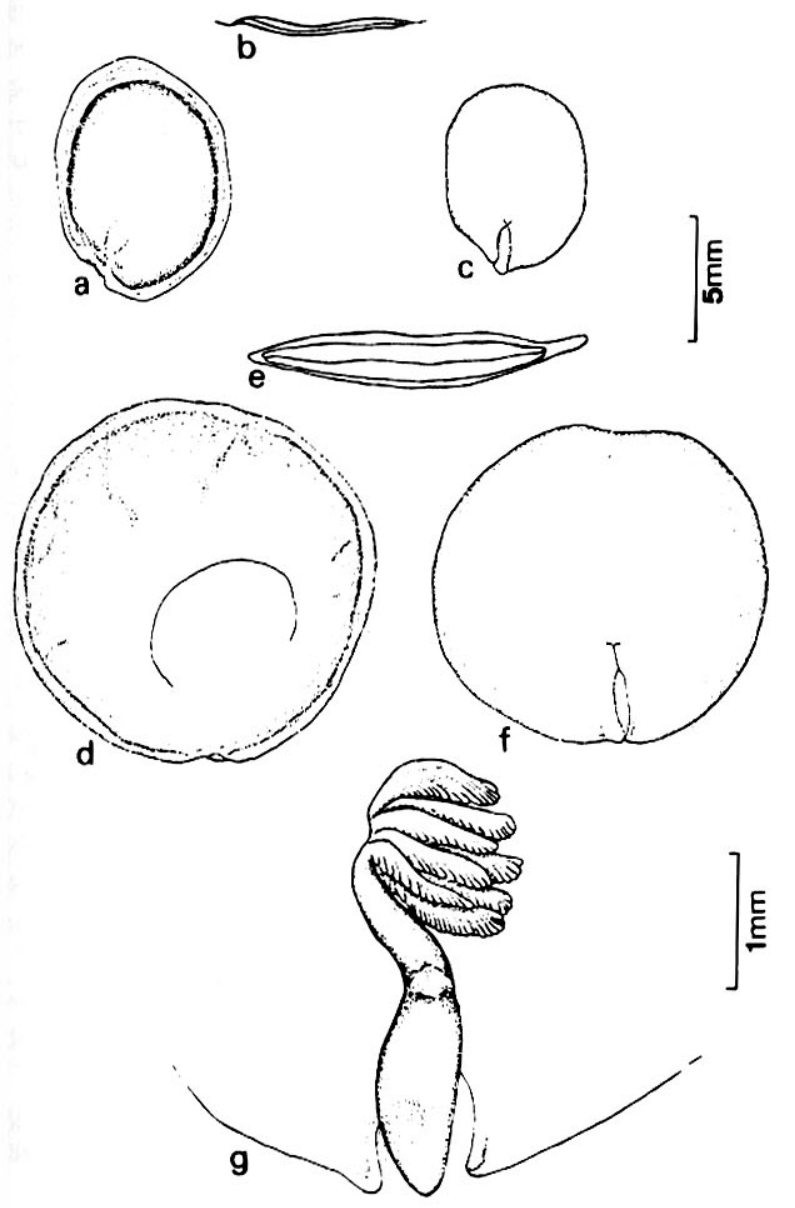

Figura 7

Anadenanthera colubrina: a - semente alada; b - secçăo transversal; c ımbriăo; Anadenanthera macrocarpa: d - semente năo alada; e - secçăo ransversal; $\mathrm{f}$ - embriåo; $\mathrm{g}$ - plúmula.

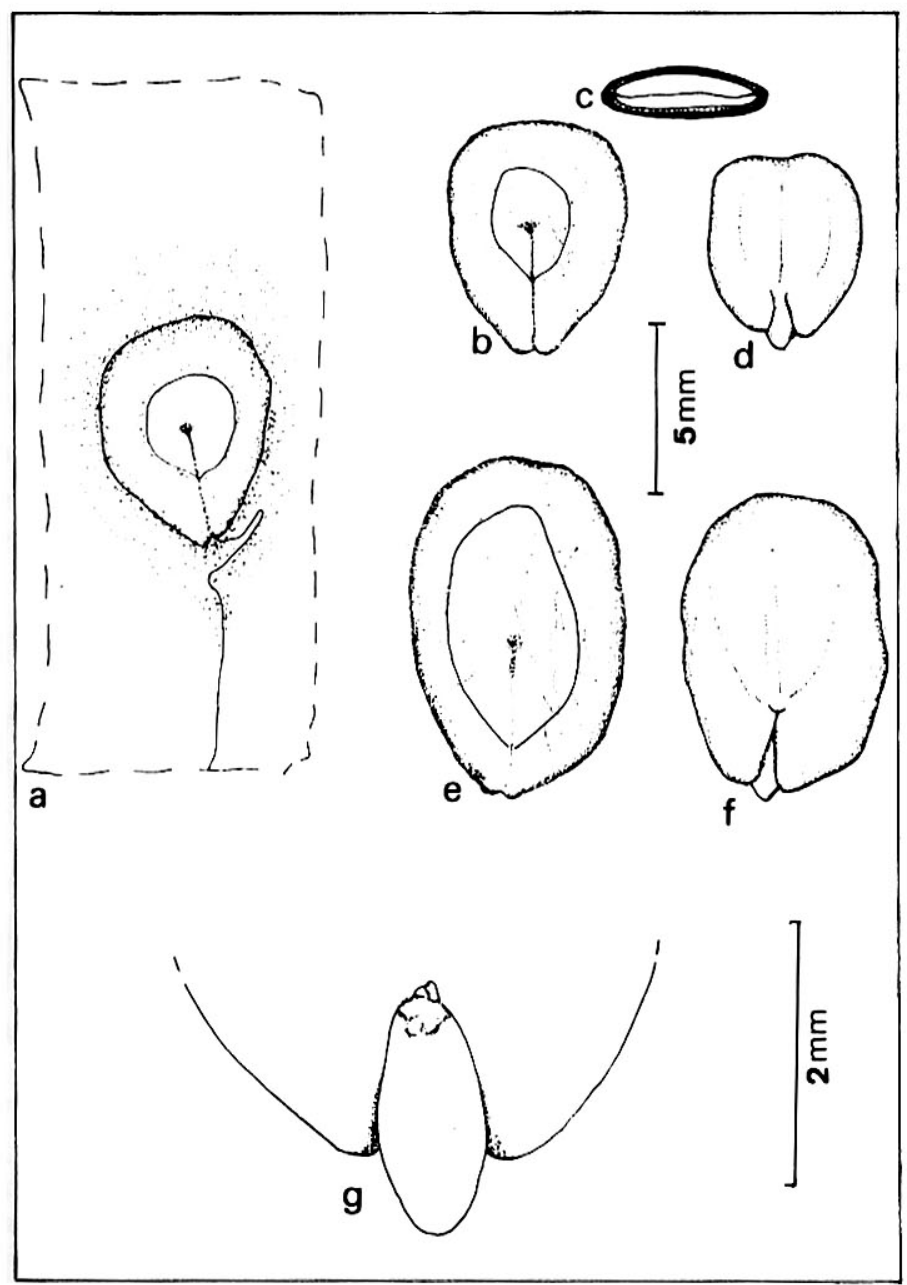

Figura 8

Plathymenia reticulada: a - semente no interior do artículo; b - semente; $c$ secçåo transversal; $d$ - embriåo; Plathymenia foliolosa: e - semente; $f-$ embriăo: $\mathrm{g}$ - plúmula. 
oblongo, plano-compresso, reto, estipitado $(2,0-2,5 \mathrm{~cm})$, epicarpo subcoriáceo, de castanho a nigrescente, nítido, liso, glabro; endocarpo segmentado; artículos monospérmicos lineares, rígido-membranáceos; margens espessadas, retas.

Semente com 0,7-1,2 cm de comprimento $\times$ 0,5-0,6 cm de largura, de obovóide a obovóide-oblonga, com faces ligeiramente convexas, não alada, transversal, com endosperma; testa de consistência rígido-membranácea, castanha, nítida, com pleurograma de mediano a apical-basal com braços semi-unidos ou unidos.

Embrião com cotilédones de 0,5$0,9 \mathrm{~cm}$ de comprimento $\times 0,4-0,6 \mathrm{~cm}$ de largura, cordado-obovóides, cordadooblongos ou cordado-suborbiculares, plano-convexos; eixo hipocótilo-radícula com $0.3 \mathrm{~cm}$ de comprimento, emergente; plúmula sem nítida diferenciação em pinas.

As espécies são facilmente reconhecidas, pois são as únicas que possuem fruto do tipo criptolomento e sementes com pleurograma cerrado (fig. 8a, b, e).

\section{Material Examinado}

Plathymenia foliolosa Benth. - BRASIL: Bahia - Anadaraí, C. T. Rizzini et A. Mattos Filho 1070 (s.d.)RB. Minas Gerais Horto Florestal de Paraopeba, E. P. Heringer s.n. (24.VII.1954), carpoteca 4052, RB; Ibidem, A. Mattos Filho et E. P. Heringer 120 (20.VII.1979) RB; a $3 \mathrm{Km}$ de Paraopeba, Fazenda do Rasgão. E. P. Heringer s.n. (30.X.1959) RB; s.l., E. P. Heringer s.n. (s.d.), carpoteca 3982, RB.

Plathymenia reticulata Benth. - BRASIL: Maranhão - 2 léguas abaixo de Carolina, Rio Tocantins, J. M. Pires et G. A. Black 2476 (29.V.1950) RB. Ceará - Serra do Araripe e arredores de Crato, $A$. Duarte et Ivone 1481 (17.VIII.1948), carpoteca 3759, RB. Minas Gerais - Belo Horizonte, Fazenda do Pastinho, M. Barreto 6431 (s.d.) R; Horto Florestal de Paraopeba, E. P. Heringer s.n. (24.VII.1954), carpoteca 4051, RB; Ibidem, A. Mattos Filho et E. P. Heringer 121 (20.VII.1959) RB; Paraopeba, E. P. Heringer s.n. (30.X.1959) RB. Rio de Janeiro, Avellar. G. M. Nunez 53 (1931) R.

\section{0 - Piptadenia Bentham \\ Bentham, in Hooker's Journ. Bot. 2:135. 1840; 4:334. 1841. \\ Fotos: $31-32 ;$ Fig. 9}

Legume com $9,0-23,0 \mathrm{~cm}$ de comprimento $\times 0,7-3,5 \mathrm{~cm}$ de largura, oblongo,

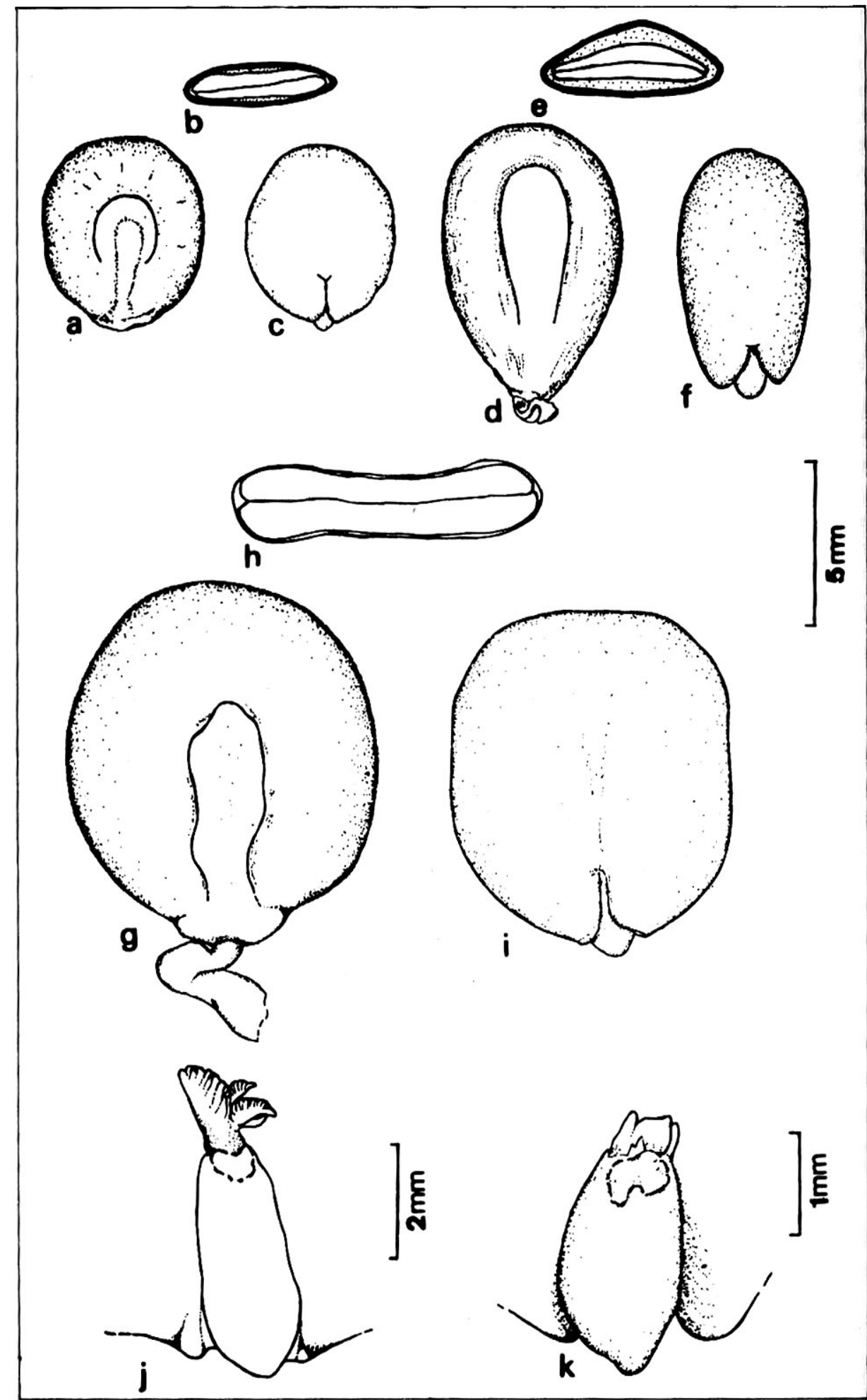

Figura 9

Piptadenia obliqua: a - semente; $\mathrm{b}$ - secção transversal; $\mathrm{c}$ - embrião; $\mathrm{k}$ - plúmula; Piptadenia fruticosa: d - semente; e - secçăo transversal; $f$ - embriăo; Piptadenia paniculata: $g$ - semente; $h$ - secçăo transversal; i - embriåo; j - plúmula.

raramente moniliforme, plano-compresso, reto ou raramente falcado, estipitado $(1,0$ $2,5 \mathrm{~cm})$, de cartáceo a subcoriáceo, de pardacento a ferrugíneo, nítido ou opaco, venoso, glabro; margens levemente espessadas, retas ou raramente constrictas.

Semente com $0,6-1,3 \mathrm{~cm}$ de comprimento $\times 0,4-1,3 \mathrm{~cm}$ de largura, orbicular, 
suborbicular ou obovóide-oblonga, com faces convexas, não alada, transversal ou raramente longitudinal, com ou sem endosperma; testa de consistência rígida a rígido-membranácea, de pardacenta a castanha, nítida, com pleurograma mediano ou apical-basal com braços afastados.

Embrião com cotilédones de 0,5 . $1,2 \mathrm{~cm}$ de comprimento $\times 0,3-1,2 \mathrm{~cm}$ de largura, cordado-orbiculares, cordadosuborbiculares ou cordado-oblongos, plano-convexos; plúmula diferenciada em pinas ou, mais raramente, sem nítida diferenciação em pinas.

0 gênero Piptadenia foi estudado de acordo com os limites estahelecidos por Brenan (1955 e 1963), o qual restringiu a este gênero as espécies com fruto legume e semente não alada, subordinando-as a duas seções: Pityrocarpa Benth. e Piptadenia. Na primeira, Brenan incluiu as espécies cujas margens do fruto são muito constrictas entre as sementes, em contraposição às margens retas do fruto que caracterizam as espécies do segundo grupo. Com base no material observado, pode-se relacionar, ainda, pra cada um dos grupos, as seguintes características:

- legume moniliforme, sementes longitudinais com endosperma e embrião com plúmula não diferenciada em pinas (Seção Pityrocarpa) Piptadenia obliqua (foto 32 ; fig. 9a-c e $9 \mathrm{k})$;

- legume não moniliforme, com margens retas, sementes transversais com ou sem endosperma e embrião com plúmula diferenciada em pinas (Seção Piptadenia) Piptadenia adinatoides, $P$. fruticosa (foto 31 ; fig. 9d-f), $P$. gonoacantha, $P$. paniculata (fig. 9g-j) $P$. laxipinna.

Em relação à presença do tecido de reserva, as sementes de Piptadenia foram consideradas por Bentham (1875, 1876), sem endosperma e, por Brenan (1955) e Burkart (1969 e 1979), com endosperma. Através do exame do material concluiu-se que o caráter é variável, pois em $P$. gonoacantha, $P$. laxipinna e $P$. paniculata (fig. $9 \mathrm{~h}$ ) as sementes não possuem endosperma, enquanto que em $P$. fruticosa (fig. 9e) e P. obliqua (fig. 9b) apresentam-se com endosperma.

\section{Material Examinado}

Piptadenia adiantoides (Spreng.) Macbr. - BRASIL: Espírito Santo - Campo nativo de Mussununga do Quirino, Reserva do
Sooretama, D. Sucre 5744 (22.VII.1969)

RB.

Piptadenia fruticosa (mart.) Macbr. BRASIL: Rio de Janeiro - s.l., A. Sampaio 3097 (VII.1918) R; Matas do Horto Florestal, J. G. Kuhlmann s.n. (12.VIII.1930), carpoteca 2439, RB; Santa Teresa, Vitório s.n. (7.V.1930) RB.

Piptadenia gonoacantha (Mart.) Macbr. BRASIL: Rio de Janeiro - Itapuca, $D$. Sucre s.n. (s.d.) RB; s.I., Sellow s.n. (s.d.) R; s.l., Idem s.n. (s.d.) R. Santa Catarina Cresciuma, H. P. Veloso 207 (s.d.) RB.

Piptadenia laxipinna G. M. Barroso BRASIL: Rio de Janeiro - Jacarepaguá, Três Rios, A. P. Duarte 5634 (25.VII.1961) RB.

Piptadenia obliqua (Pers.) macbr. - BRASIL: Piauí - Pedro Il, Serra dos Motões, $D$. Sucre et J. F. da Silva 9298 (24.VI.1972) RB. Ceará - Tianguá, O. A. Salgado 43 (4.VIII.1978) RB. Pernambuco - petrolina, Reserva da Embrapa, R. F. Monteiro et al. 10180 (19.VII.1979) UEC; arredores de Petrolina, E. P. Heringer et al. 102 (18.IV.1971) RB.

Piptadenia paniculata Benth. - BRASIL: Rio de Janeiro - Santa Maria Magdalena, D. Constantino s.n. (s.d.) RB.

\section{1 - Parapiptadenia Brenan Brenan, Kew Bull. 17:228. 1963. Fotos: 33-34; Fig. 10}

Legume com $7,0-22,0 \mathrm{~cm}$ de comprimento $\times 1,0-3,5 \mathrm{~cm}$ de largura, oblongo, plano-compresso, reto, estipitado 10,3 $1.5 \mathrm{~cm}$ ), de cartáceo a subcoriáceo, de pardacento a castanho-escuro, opaco ou nítido, venoso, glabro; margens levemente espessadas, sinuosas.

Semente com 1,0-1,5 cm de comprimento $\times 1,0-2,7 \mathrm{~cm}$ de largura, subtransverso-oblonga, transverso-oblonga ou, mais raramente, suborbicular, com faces planas, de amplamente a estreitamente alada, longitudinal, sem endosperma; testa de consistência membranácea, pardacenta, opaca, sem pleurograma.

Embrião com cotilédones de 0,5 $0,8 \mathrm{~cm}$ de comprimento $\times 0,8-2,0 \mathrm{~cm}$ de largura, cordado-obreniforme-transversooblongos, planos; eixo hipocótilo-radícula com 0,2-0,4 cm de comprimento, emergente; plúmula diferenciada em pinas.

As espécies de Parapiptadenia são muito afins das de Piptadenia, porém, diferenciam-se pelas sementes aladas, planas, com testa muito tênue não marcada por pleurograma (fig. 10a).
Material Examinado

Parapitadenia blanchetii (Benth.) Vaz et M.P. Lima - BRASIL: Bahia - Amargosa, A. P. Araújo 123 (s.d.) RB.

Parapiptadenia pterosperma (Benth.) Brenan - BRASIL: Minas Gerais - Reseva Florestal do Rio Doce, Ponte Queimada, $G$. Martinelli et al. 50 (30.VIII.1973) RB.

Parapiptadenia rigida (Benth.) Brenan BRASIL: São Paulo - Itapetinga, J. l. de Lima s.n. (s.d.) RB. Paraná - Guarapuava, G. Hatschbach et al. 16536 (16.VI.1967) HB. Santa Catarina - Joaçaba, na margem oeste do Rio do Peixe, $L$. B. Smith et $R$. Klein 11907 (27.1.1957) R. PARAGUAl: Capiata - arroio capiata, P. Arenas 1177 (20.IV.1975) HB.

\section{2 - Desmanthus Willdenow Willdenow, Sp. PI. 4(2):888, 1044. 1806. \\ Foto: 35; Fig. $11 \mathrm{a}-\mathrm{d}$}

Legume com $3,0-10,0 \mathrm{~cm}$ de comprimento $\times 0,3-0,5 \mathrm{~cm}$ de largura, amplamente linear, plano-compresso, reto ou subfalcado, séssil, cartáceo, pardacento, castanho-avermelhado ou nigrescente, nítido venoso, glabro; margens espessadas, retas.

Semente com 0,3-0,5 cm de comprimento $\times 0,2-0,3 \mathrm{~cm}$ de largura, obovóide, com faces convexas, não alada, oblíqua, com endosperma; testa de consistência rígido-membranácea, de pardacenta a castanha, nítida, com pleurograma mediano com braços afastados.

Embrião com cotilédones de 0,2$0,3 \mathrm{~cm}$ de comprimento $\times 0,2-0,3 \mathrm{~cm}$ de largura, cordado-orbiculares, plano-convexos; eixo hipocótilo-radícula com $0,3 \mathrm{~cm}$ de comprimento, emergente; plúmula sem nítida diferenciação em pinas.

O fruto de Desmanthus (foto 35) como mencionado por Isely (1970), apresenta grande afinidade com o de Neptunia, diferindo deste por sua forma amplamente linear. As sementes, dispostas obliquamente e não de forma longitudinal como descrito por Windler (1966), caracterizam-se, principalmente, pelo pleurograma mediano (fig. 11a).

\section{Material Examinado}

Desmanthus depressus Humb. et Bompl. ex Willd. - BRASIL: Minas gerais - Belo Horizonte, Curvelo, P. Gibbs et al. 2527 (30.VII.1976) UEC; Salinas, Km 10 Estrada para Pedra Azul, H. F. Leitão Filho et al. 7905 (25.V.1978) UEC. 


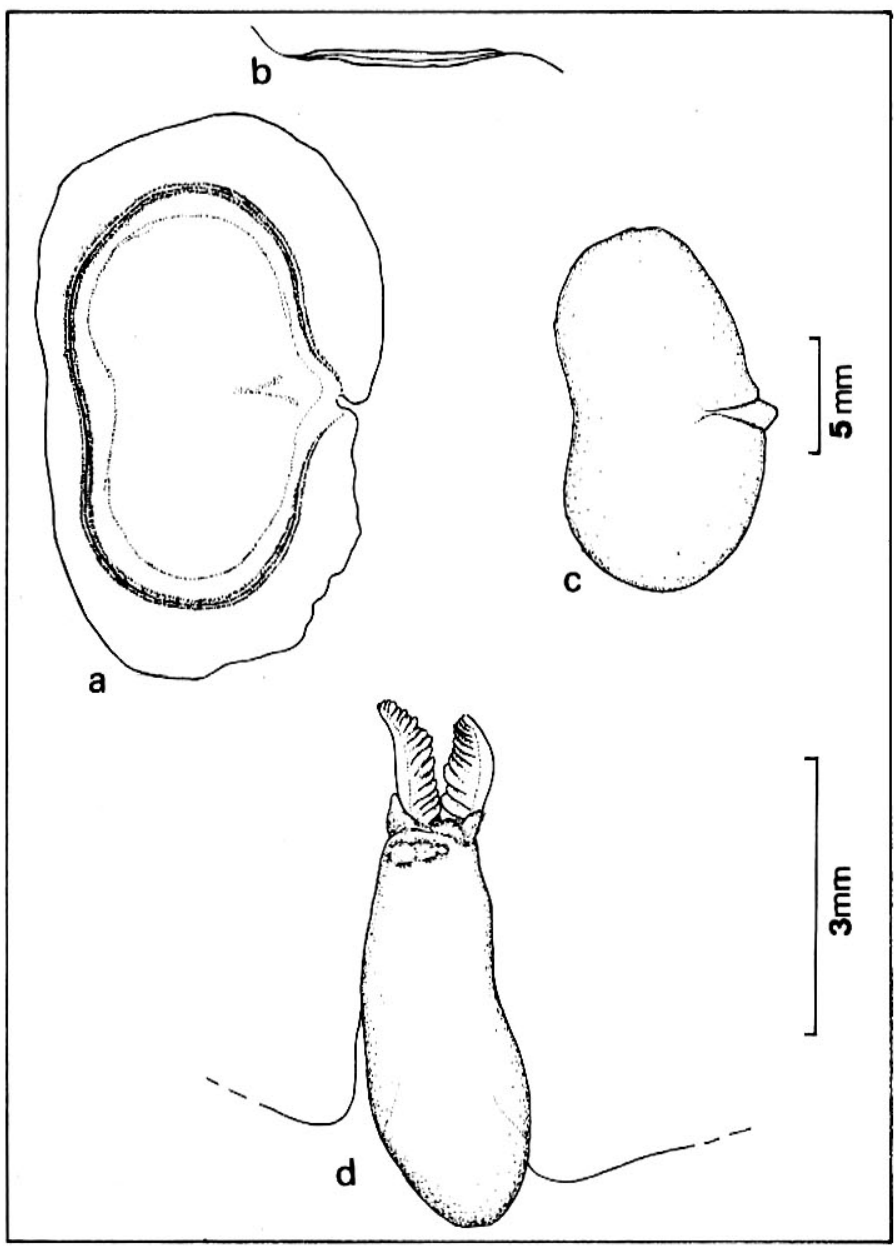

Figura 10

Parapiptadenia pterosperma: a - semente alada; b - secçăo transversal; $\mathrm{c}-$ embriăo; d - plúmula.

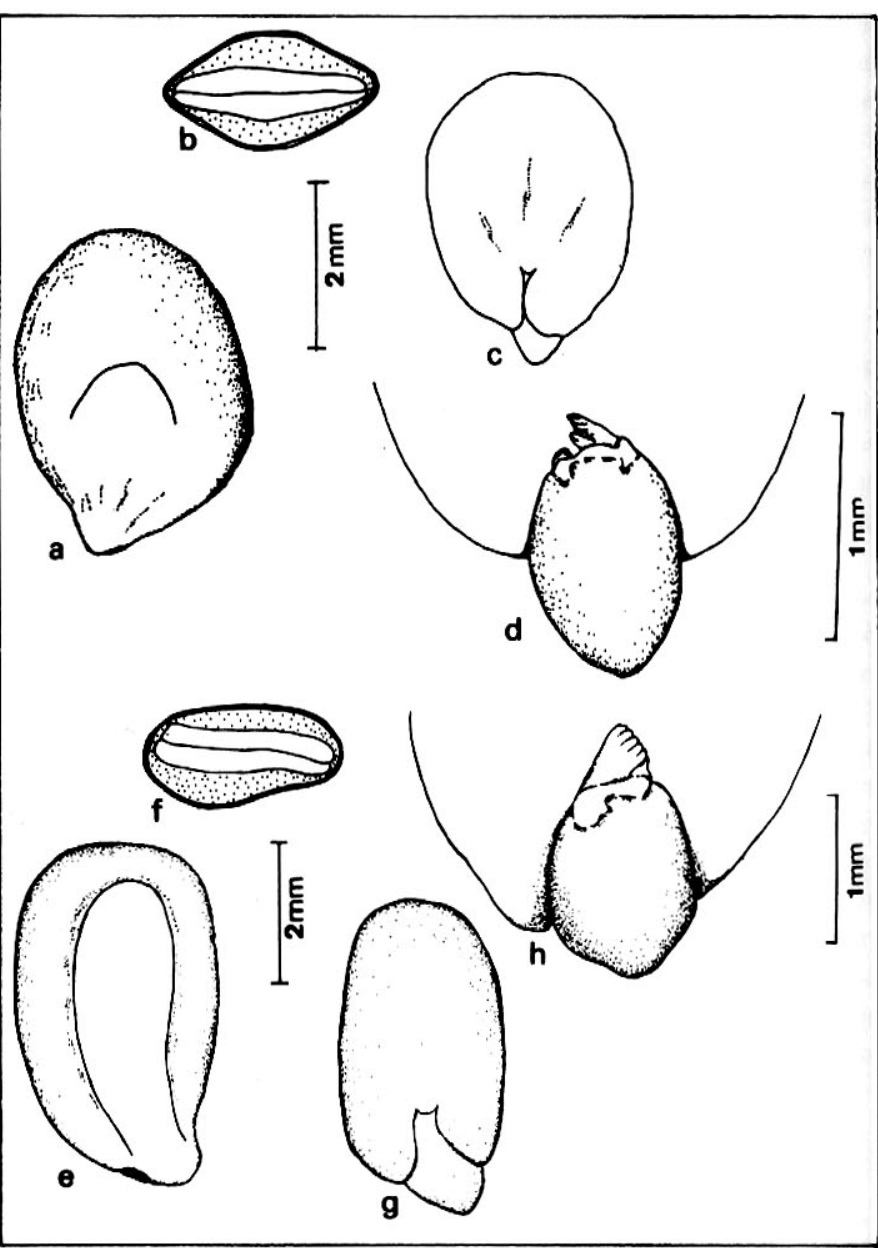

Figura 11

Desmanthus virgatus: a - semente; b - secçăo transversal; c - embriåo; $d$ plúmula; Neptunia oleracea: e - semente; $\mathrm{f}-$ secçăo transversal; $\mathrm{g}-\mathrm{em}$. briâo; $\mathrm{h}$ - plúmula.
Desmanthus tatuhyensis F. C. Hoehne BRASIL: São Paulo - Itapetininga, J. I. de Lima s.n. (13.XI.1946) RB. Paraná - Porto Amazonas, Gurge/ 10 (17.XII.1929) RB. Santa Catarina - Campo dos Cantisanos, Rio das Pedras, F. Muller 96 (s.d.) R; Capinzal L. B. Smith et R. klein 11924 (28.II.1957) R.

Desmanthus virgatus (L.) Willd. - BRASIL: Ceará - Serra de Baturité, Sítio B. Inácio de Azevedo, J. Eugênio (S.J.) 593 (11.V.1939) RB; s.l. F. C. Camargo s.n. (s.d.) R. Paraíba - Estrada Paraíba, S. Gonçalo Souza, Comn. Serv. Compl. da Inspetoria F.O.C. Seccas 45 (1935) RB. Pernambuco - Caruaru, P. H. Davis et D. A. Lima 61137 (25.IX.1976) UEC. Rio de Janeiro - Jardim Botânico, J. G. Kuhlmann s.n. (11.IX.1939) RB; Niterói, Ponta de Itaipu, V. F. Ferreira et al. 456 (6.IX.1978) RB.

\section{3 - Neptunia Loureiro} Loureiro, FI. Cochinch. 2:641, 653. 1790.

\section{Foto: 36; Fig. $11 \mathrm{e}-\mathrm{h}$}

Legume com $3,0-5,0 \mathrm{~cm}$ de comprimento $\times 0,8-1,0 \mathrm{~cm}$ de largura, amplamente oblongo, plano-compresso, subfalcado, estipitado $(0,3-1,0 \mathrm{~cm})$, cartáceo, de castanho a nigrescente, opaco, venoso, glabro; margens não espessadas, retas ou sinuosas.

Semente com 0,4-0,5 cm de comprimento $\times 0,2-0,3 \mathrm{~cm}$ de largura, obovóide, obovóide-oblonga, com faces convexas, năo alada, transversal ou oblíqua, com endosperma; testa de consistência rígida, de pardacenta a castanha, nítida, com pleurograma apical-basal com braços afastados.

Embrião com cotilédones de $0,4 \mathrm{~cm}$ de comprimento $\times 0,2-0,3 \mathrm{~cm}$ de largura, cor- dado-suborbiculares ou cordado-oblongos, plano-convexos; eixo hipocótilo-radícula com 0,2 cm de comprimento, emergente; plúmula sem nítida diferenciação em pinas.

Como mencionado anteriormente, Neptunia e Desmanthus apresentam afinidade em relação ao legume Windler (1966), em sua revisão sobre o gênero Neptunia, considerou que a principal diferença entre ambos os gêneros está na posição da semente, que em Desmanthus, segundo o autor, é longitudinal, enquanto que em Neptunia é transversal ou oblíqua Porém, este caráter não deve ser conside. rado, uma vez que, como mencionou Isely (1970), as sementes oblíquas ocorrem em ambos os gêneros.

0 legume em Neptunia caracteriza-se, principalmente, pela forma amplamente oblonga, diferenciando-se, assim, do legu- 
me linear de Desmanthus. A semente distingue-se, principalmente, da de Desmanthus, pelo pleurograma apical-basal (fig. 11e).

\section{Material Examinado}

Neptunia oleracea Lour. - BRASIL: Pará - s.l., F. C. Camargo s.n. (1952) IAN. Maranhão - São Bento, Alegre, N. A. Rosa 2523 (4.VII.1978) UEC; Viana, A. Aguire s.n. (26.VI.59) RB; s.I., O. C. de Viana 6 (1955) RB.

Neptunia plena (L.) Benth. - BRASIL: Ceará - Fortaleza, lagoa do Tauape, F. Dromet 2565 (5.X.1935) R.

\section{4 - Prosopis Linnaeus}

Linnaeus, Mantissa PI. 7:68. 1767. Foto: 37 ; Fig. 12

Lomento drupáceo com 20,0-26,0 cm de comprimento $\times 1,0-1,5 \mathrm{~cm}$ de largura, linear-oblongo, subcilíndrico, de subfalcado a falcado, estipitado $(2,0 \mathrm{~cm})$, epicarpo cartáceo, pardacento, opaco, venoso, glabro; mesocarpo pulposo-granuloso; endocarpo coriáceo, segmentado, artículos monospérmicos, de retangulares e subquadrangulares; margens espessadas, sinuosas.

Sementes com 0,7-0,8 cm de comprimento $\times$ 0,4-0,5 cm de largura, elipsóide, com faces levemente convexas, não alada, transversal ou suboblíqua, com endosperma; testa de consistência rígido-membranácea, castanha, nítida, com pleurograma apical-basal com braços afastados.

Embrião com cotilédones de 0,5$0,6 \mathrm{~cm}$ de comprimento $\times 0,4-0,5 \mathrm{~cm}$ de largura, cordado-suborbiculares, planoconvexos; eixo hipocótilo-radícula com $0,2 \mathrm{~cm}$ de comprimento, emergente; plúmula sem nítida diferenciação em pinas.

$O$ fruto de Prosopis é facilmente idenficado entre os frutos dos demais gêneros, por ser o único nas Mimoseae com características de lomento drupáceo.

Devido a escassez de material frutífero, a descrição genérica está baseada apenas na observação do fruto e da semente de $P$. hass/eri, uma das quatro espécies ocorrentes no Brasil. Porém, segundo as descrições de Burkart (1943, 1976), o lomento drupáceo é o tipo de fruto característico das espécies deste gênero.

\section{Material Examinado}

Prosopis hassleri Harms - BRASIL: Mato

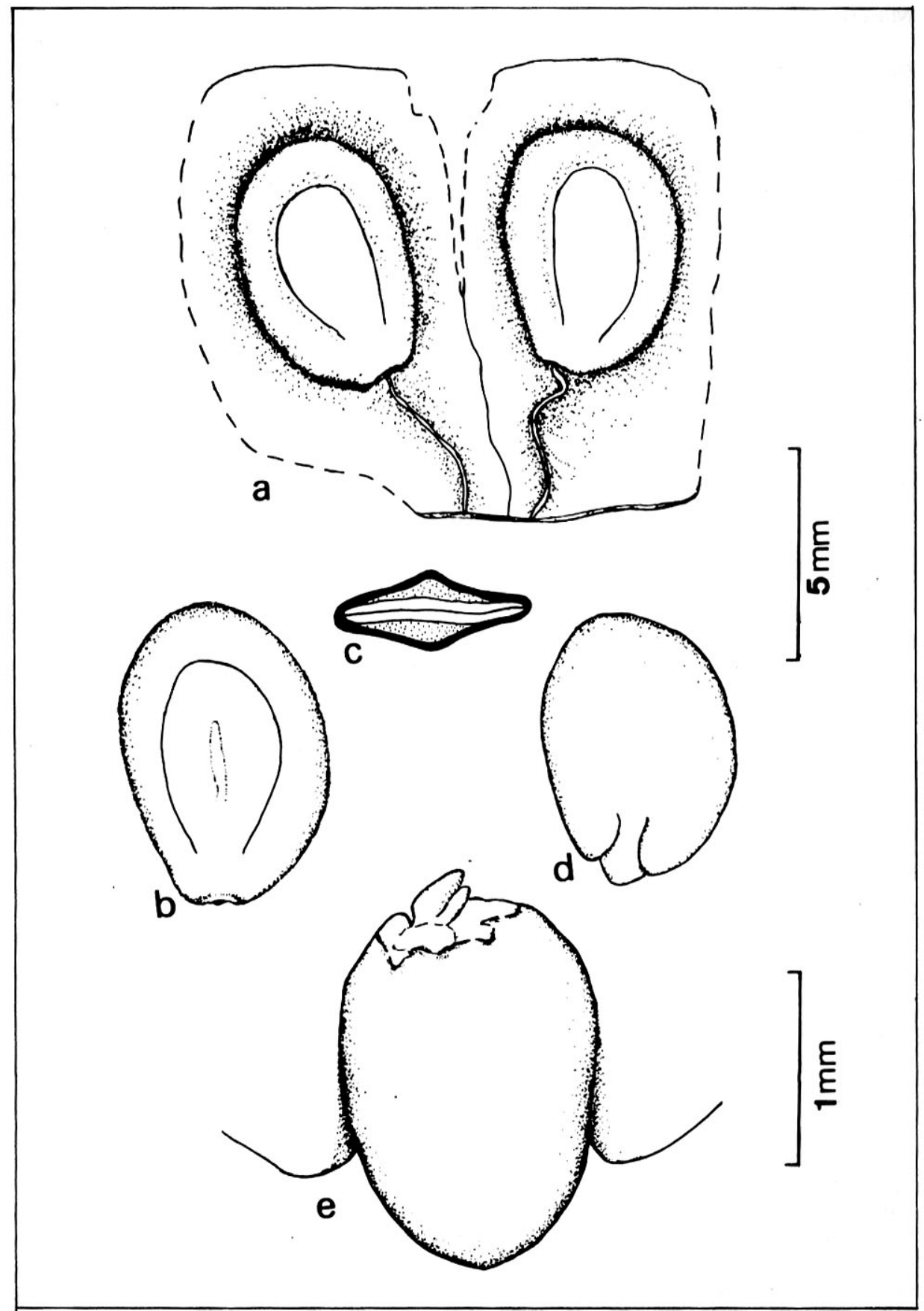

Figura 12

Prosopis hass/eri: a - semente no interior do artículo; $\mathrm{b}$ - semente; $\mathrm{c}$ - secção transversal; $\mathrm{d}$ - embrião: e-plúmula.

Grosso - Corumbá, margem do rio Paraguai, E. Pereira et al. 120 (1.X.1953) RB.

\section{5 - Dinizia Ducke}

Ducke, Arch. Jard, Bot. Rio de Janeiro, 3:76. t. 4. 1922

Foto: 38

Samaróide com $25,5-30,0 \mathrm{~cm}$ de comprimento $\times 4,5-6,5 \mathrm{~cm}$ de largura, oblongo, plano-compresso, reto, estipitado $(1,5 \mathrm{~cm})$ subcoriáceo, de pardacento a castanho, nítido, venoso, rugoso, glabro; margens não espessadas, retas, unilateralmente expandida em ala.

Semente transversal, comprimida com cerca de 10 a $12 \mathrm{~mm}$ de comprimento $x 7 \mathrm{~mm}$ de largura; testa dura nítida, fusconigrescente; embrião incluso em endosperma crasso semitranslúcido. (Ducke 1922) 


\section{Material Examinado}

Dinizia exce/sa Ducke - BRASIL: Amazonas - Manaus, Estrada das terras altas além da Colônia João Alfredo, A. Ducke 707 (9.V.1941) MG, (S/S). Pará — Amerim, Monte Dourado estrada do sul do Pacanari, M. R. Santos 451 (2.XII.1978) MG, (S/S): arredores da Serra do Curumun, A. Ducke 15774 (1.X.1915) RB. (S/S); Rio Tapajós, Bela Vista, A. Ducke 15826 (6.XII.1915) RB, (S/S); Rio Tapajós, Furnas, A. Ducke s.n. (s.d.) carpoteca 486, RB, (S/S); Rio Tapajós, Região das cachoeiras inferiores, A. Ducke s.n. (26.VI.1918) RB, (S/S).

\section{Discussão e Conclusão}

Os sistematas, em geral, vêm descrevendo, os frutos da tribo Mimoseae, denominando-os, indiscriminadamente, de legume, ou simplesmente, fruto. Os tipos de frutos, neste trabalho, foram definidos segundo os conceitos de Burkart (1943) e Barroso (no prelo). De forma geral, concordou-se com a definição de ambos os autores acima citados, porém, os frutos de determinados gêneros requerem maior discussão.

Entre os tipos classificados por Burkart, (1.c.), o de Schrankia foi definido por ele e, posteriormente, por Bravato (1974), como legume de margens aculeadas. Entretanto, a persistência das margens, após a queda das "valvas", mencionada anteriormente nas descrições de Bentham (1875, 1876), Hutchinson (1967), Elias (1974) e Lewis e Elias (1981), foi verificada ao examinar-se os frutos do referido gênero, evidenciando-se assim, a diferenciação das margens em replum. Além disto, no respectivo fruto não há a formação das valvas típicas do legume. Assim sendo, devido a presença do replum no fruto de Schrankia e, ainda por este afastar-se muito da forma bivalvar típica do legume, concorda-se com a classificação de BARROSO, (I.c.), que incluiu-o no grupo de Mimosa e entada, como pertencente ao tipo craspédio. O processo de segmentação do craspédio de Schrankia leva a se supor que este tipo de craspédio seja uma forma intermediária entre os craspédios articulados e aqueles de valvas contínuas.

Ainda em relação aos frutos classificados por Barroso, (I.c.), ao de Stryphnodendron, foi atribuído o nome de legume carnoso. Bravato, (l.c.), considerou-o como legume com deiscência tardia ou legume bacóide. Ao examinar-se esse fru- to, observou-se que a forma de deiscência é variável, uma vez que foram observados frutos maduros tardiamente deiscentes, inicialmente de forma folicular e, posteriormente bivalvar semelhante ao legume, além de frutos maduros ainda indeiscentes. Quanto à carnosidade, presente na maioria das espécies examinadas, verificou-se que esta não chega a formar substância pulposa envolvendo as sementes, como é peculiar, segundo as definições de Burkart, (l.c.), e Barroso, (l.c.), nos frutos do tipo legume bacáceo. Por estes motivos, manteve-se a denominação de legume carnoso, provisoriamente, para o fruto de Stryphnodendron (exceto em S. gracile), até que maior quantidade de frutos, em estado natural, sejam examinados.

Além dos frutos anteriormente definidos por Burkart, (I.c.) e Barroso, (I.c.), foram classificados para a tribo Mimoseae os tipos sacelo e samaróide. O sacelo está relacionado com os frutos observados em Mimosa meticulosa e Mimosa acerba, que foram utilizados por Burkart (1979:133) em sua chave, como caráter para a identificação das espécies de Mimosa ocorrentes em Santa Catarina. Tais estruturas foram denominadas por Burkart, (I.c.), como "lomento oboval não articulado, deiscente no ápice, valvas năo separadas do replum". Neste mesmo trabalho, ao descrever tais espécies, refere-se, ainda, a vagens e frutos deiscentes, bivalvos, não articulados. Através das descrições divergentes do autor acima mencionado, e do exame de material, concluiu-se que ambas as designações, lomento e vagem, são impróprias para esses frutos, uma vez que não há a formação de artículos como é característico no lomento e, embora haja semelhança com o tipo legume, deste difere, principalmente, pela forma de deiscência. Por estas razões, adotou-se o termo sacelo (Mannagetta 1913), que caracteriza o fruto com deiscência transverso-apical, mantendo-se as valvas unidas. Tal tipo de fruto sugere a sua origem de um craspédio articulado, encontrado na grande maioria das espécies de Mimosa, o qual teria sofrido uma regressão em relação ao replum e número de artículos, reduzindo-se a um frutículo deiscente.

Ao fruto de Dinizia, denominado por Ducke (1922), Hutchinson (1967) e Barroso (no prelo) de legume indeiscente, foi atribuída a denominação samaróide, devido a expansão unilateral aliforme e a sua dispersão pelo vento.

Ao contrário do conceito de Dudik (1981), o termo legume foi utilizado neste trabalho, em sensu stricto, para caracterizar os frutos secos, com deiscência regular, dorsiventral e os demais tipos de frutos dos gêneros da tribo Mimoseae foram reco. nhecidos como folículo, sacelo, legu: me carnoso, criptolomento, craspé. dio, lomento drupáceo e samaróide. Por outro lado, aceita-se a hiṕotese de que esta diversidade nos tipos de "legume" é con. seqüência de diferentes adaptações à dis. persão. Isto não impede, porém, que se utilize uma terminologia específica para definir os frutos que sofreram tais altera. ções morfológicas.

Em oposição ao que afirmou Bravato (1974), ao colocar em dúvida o valor taxo. nômico do fruto, na sistemática de Mimo. soideae, concluiu-se que os gêneros estu* dados podem ser caracterizados através $d \theta$ seus frutos.

As sementes dos gêneros da tribo $\mathrm{Mi}$ moseae e suas estruturas externas e inter. nas enquadram-se, de forma geral, nas descrições para a subfamília Mimosoideae apresentadas pelos autores citados na revisão bibliográfica. Concordou-se com 0 conceito de Isely $(1947,1955)$ em rela. çăo a posição basal do hilo, o qual é coerente, inclusive com a definição de Murley (1951) sobre a base de um órgão. Desta forma, as classificações apical, suba. pical e mediano, utilizadas por Boelcke (1946) e Bravato (1974), em suas des. crições a respeito do hilo, não foram aplica. das.

A presença de ala, que segundo Gunn (1981) na subfamília Mimosoideae é pe. culiar às sementes da tribo Mimoseae, constitui um caráter de grande valor taxo. nômico pois possibilita a identificação de gêneros afins. As sementes aladas são constantes nas espécies de Pseudopiptadenia, Newtonia e Parapiptadenia.

Nas sementes não aladas, verificou-se a presenca constante do pleurograma. Os pleurogramas das sementes da tribo $\mathrm{Mi}$ moseae são, muitas vezes, intermediários entre os tipos apresentados por Gunn (1981), estabelecidos, por este autor, em relação a seu grau de abertura. Por este motivo, neste trabalho, classificou-se 0 pleurograma de-acordo com a região que abrange na semente. Ainda em relação ao pleurograma, Gunn (l.c.), após abordar a atuação do hilo como válvula higroscópica nas sementes duras de Papilionoideae, co. menta que Hyde, em trabalho não concluído, sugeria que o pleurograma nas sementes de Albizia também funcionasse como válvula higroscópica. Através do estudo morfológico das sementes da tribo Mimo. 
seae, observou-se que nas sementes com testa muito rígida, como as de Entada, Mimosa pp., Neptunia e Stryphnodendron, o pleurograma atinge maior extensão e naquelas em que a testa é de consistência tênue, tal estrutura é geralmente ausente ou levemente marcada. Tais observações levam a supor que realmente o pleurograma atua como válvula higroscópica. Porém é necessário que se façam estudos detaIhados sobre a função de tal estrutura.

Em relação às estruturas embrionárias, destaca-se a plúmula que, por sua forma diferenciada e constante nos gêneros Anadenanthera, Newtonia, Parapiptadenia e Schrankia, pode ser utilizada como bom caráter na sistemática dos referidos taxons. Em Mimosa, devido aos diversos graus de diferenciação da plúmula em pinas, a utilização desta estrutura como caráter taxonômico, restringe-se a grupos de espécies. Nos demais gêneros estudados, onde tal diferenciaçao não é aparente, torna-se difícil a análise da plúmula, devido às dimensões diminutas.

Para finalizar, conclui-se que o fruto, a semente e o embrião dos gêneros da tribo Mimoseae fornecem dados importantes ao estudo sistemático desses taxons.

\section{Abstract}

The work presented here consists of a morphological study of the fruits, seeds and embryos of the fifteen genera of the tribe Mimoseae Bronn (Leguminosae-Mimosoideae) occuring in Brazil. The taxa, in relation to their structure, are described and identified by a dichotomus key.

The fruits are classified into eight types, principally considering the dehiscent and indehiscent forms, the morphology of the pericarp and the presence or absence of a replum. In relation to the seeds two groups distinguish themselves: those with winged seeds and those with seeds ones without wings. The degree to which the plumule differentiates itself into pinnae within the embryo constitutes a good taxonomic character useful in recognizing some genera.

\section{Referências Bibliográficas}

ADANSON, M. Entada. In: Familles des plantes. Paris, Vincent, 1763. v. 2, p. 318.

BARROSO, G. M. Curso sobre identificação de sementes. Mimeo. MEC, UPFEL, CETREISUL, FAEM., 36 p., 1976-78. il.

BARROSO, G. M. et col. Sistemática de Angiospermas do Brasil, v. 2. Ed. Uni- versidade Federal de Viçosa. 377 p.

BENTHAM, G. Contributions towards a flora of South America. - Enumeration of plants collected by Mr. Schomburgk in British Guiana. (tribe Mimoseae). In: Hooker's Journ. Bot., 2(11):127-46, 1840.

. Notes on Mimoseae, with a short synopsis of species (Plathymenia e Piptadenia). In: Hooker's journ. Bot., 4(30-31):333-41, 1841(42).

Revision of the suborder Mimoseae. The Trans. Linn. Soc. London, 30(3):335-664, 1875. il.

Leguminosae-Mimosoideae. In:Martius. Flora Brasiliensis. Monachii, Regia C. Wolf et Fil., B. Keller, 1876. v. 15, pt. 2, p. 258-503.

BOELCKE, O. Estudo morfológico de las semillas de Leguminosas Mimosoideas y Caesalpinoideas de interés agronómico en la Argentina. Darwiniana, $7(2): 240-321,1946$. il.

BRAVATO, M. Estudo morfológico de frutos y semillas de las Mimosoideae (Leguminosae). Acta. Bot. Venezuela, 9(1-4):317-61, 1974. il.

BRENAN, J.P.M. Notes on Mimosoideae: I. Kew Bull., 10(2):161 -92, 1955.

BRENAN, J. P. M. Notes on Mimosoideae: VIII. Kew Bull., 17(2):227-8, 1963.

. Notes on Mimosoideae: XI. Kew Bull., 20(3):361-78, 1966.

BURKART, A. Las Leguminosas Argentinas. Buenos Aires, Acme Agency, 1943. 590 p. il.

Las especies de Mimosa de la flora Argentina. Darwiniana, 8(1):9231, 1948. il.

. Sinopses de las especies de Mimosa de la serie Lepidotae. Darwiniana, 13(2-4):343-427, 1964. il.

. Leguminosas nuevas o criticas, VII. Darwiniana, 15(3-4):501-49, 1969. il.

. A monograph of the genus Prosopis (Leguminosae subfam. Mimosoideae). Journ. Arn. Arb., 57(3-4): 219-49; 450-525, 1976. il.

Leguminosas Mimosoideas. In: Reitz, P. R. Flora /l/ustr. Catar., 1-299, 1979. il.

CANDOLLE, A. P. DE. Leguminosae. In: Prodomus systematis naturalis regni vegetabilis. Paris, Treuttel et Würtz, 1825. v. 2, p. 93-524.

CORNER, E. J. H. The leguminous seed. Phytomorphology 1:117-50, 1951. il. . The seeds of Dicotyledons. Cambridge, University Press, 1976. 2 v., il.
DUCKE, A. Plantes nouvelles ou peu connues de la région amazonienne (Dinizia). Arq. Jard. Bot. Rio de Janeiro, 3: 76-7, 1922. il.

DUDIK, N. M. Morphology of the pods of Leguminales (Fabales). In: Polhill, R. M. and Raven, P. H. Advances in legume systematics, Kew, Crown Copyright, 1981. v. 2, p. 897-901. il.

DUKE, J. A. Keys for the identification of seedlings of some prominent woody species in eight forest types in Puerto Rico. Ann. Missouri Bot. Gard., 52(3): 314-50, 1965. il.

. On tropical tree seedlings I. Seeds, seedlings, systems, and systematics. Ann. Missouri Bot. Gard. , 56(2): 125-61, 1969. il. et POLHILL, R. M. Seedlings of Leguminosae. In: Polhill, R. M. and Raven, P. H. Advances in legume systematics, Kew, Crown Copyright, 1981. v. 2, p. $941-9$, il.

ELIAS, T. S. The genera of Mimosoideae (Leguminosae) in the southeastern United States. Journ. Arn. Arb., 55: 67-118, 1974. il.

FONT QUER, P. Dicionário de Botánica. 5 ed. Barcelona et alli, Editorial Labor, S.A. 1975. 1244 p., il.

GAERTNER, J. Leguminosae. In: De fructibus et seminibus plantarum, Tubingiae, 1791. v. 2, p. 301-52.

GUNN, C. R. Seeds of Leguminosae. In: Poihill, R. M. and Raven, P. H. Advances in legume systematics, Kew, Crown Copyright, 1981, v. 2, p. 91325, il.

HERTEL, R. J. G. Contribuição para a fitologia teórica. II Alguns conceitos na carpologia. Humanitas 4(4): 1-43, 1959.

HUTCHINSON, J. Mimosaceae. In: The Genera of flowering plants (Angiospermae). Oxford, University Press, 1967. v. 1, p. 277-97.

ISELY, D. Investigations in seed classification by family characteristics. lowa Agric. Expt. Sta. Res. Bull., 351:31780, 1947. il.

Key to seeds of Caesalpinoideae and Mimosoideae of north central States. Proc. lowa Acad. Sci., 62: 146-9, 1955a. il

Observations on seeds of the Leguminosae: Mimosoideae and Caesalpinoideae. Proc. lowa Acad. Sci. 62:142-5, 1955b. il.

Legumes of the United States: II. Desmanthus and Neptunia. lowa 
State Journ. Sci., 44(4):495-511, 1970.

KOPOOSHIAN, H. et ISELY, D. Seed character relationships in the Leguminosae. Proc. lowa Acad. Sci., 73:59-67. 1966. il.

LAWRENCE, G. H. M. Taxonomia das plantas vasculares. Lisboa, Fundação Calouste Gulbenkian, 1951.v. 2, p. 767 809, il.

LEWIS, G. P. et ELIAS, T. S. Mimoseae Bronn. In: Polhill, R.M. and Raven, P. $\mathrm{H}$. Advances in legume systematics. Kew, Crown Copyright, 1981. v. 1, p. 155-68, il.

LINNAEUS, C. Mimosa. In: Species plantarum. Holmiae, 1753. v. 1, p. 516-7. Prosopis. In: Mantissa planta- rum 1767 \& 1771. New York, Wheldon \& Wesley, 1971. p. 68 (reimpressão).

LOUREIRO, J. DE. Neptunia. In: Flora cochinchinensis. Ulyssipone, Typis et Expensis Academicis, 1790. V. 2. p. 641, 653-4.

MANNAGETTA, G. B. von. Frucht und Same. Handwortbuch Naturwiss, 1913.

MARTIN, A. C. The comparative internal morphology of seeds. Amer. Midl. Nat. 36(3):513-660, 1946. il.

MARTIUS, C. F. P. von. Stryphnodendron. In: Herbarium florae brasiliensis. Monachii, 1837 . v. 20 pt. 2, p. 117.

MURLEY, M. R. Seeds of the Cruciferae of northeastern North America. Amer.
Midl. Nat. 46(1): 1-81, 1951. il.

RIZZINI, C. T. Sistematização terminológica da folha. Rodriguésia, 29(42): 103-25, 1977. il.

SPEGAZZINI, C. Algumas observaciones relativas al suborden de las Mimosoi. deas. Physis, 6(22):308-15, 1923(22).

STEARN, W. T. Descriptive terminology. In: Botanical latin. New York, Hafner Publishing Company, 1966. p. 311. 57, il.

WILLDENOW, C. L. Schrankia \& Desmanthus. In.: Linnaues Species plantarum. 4 ed., Berolini, G. C. Naux, 1806. v. 4 , pt. 2, p. 888, 1041-45.

WINDLER, D. R. A revision of the genus Neptunia (Leguminosae). Austral. Journ. Bot., 14:379-420, 1966. il.

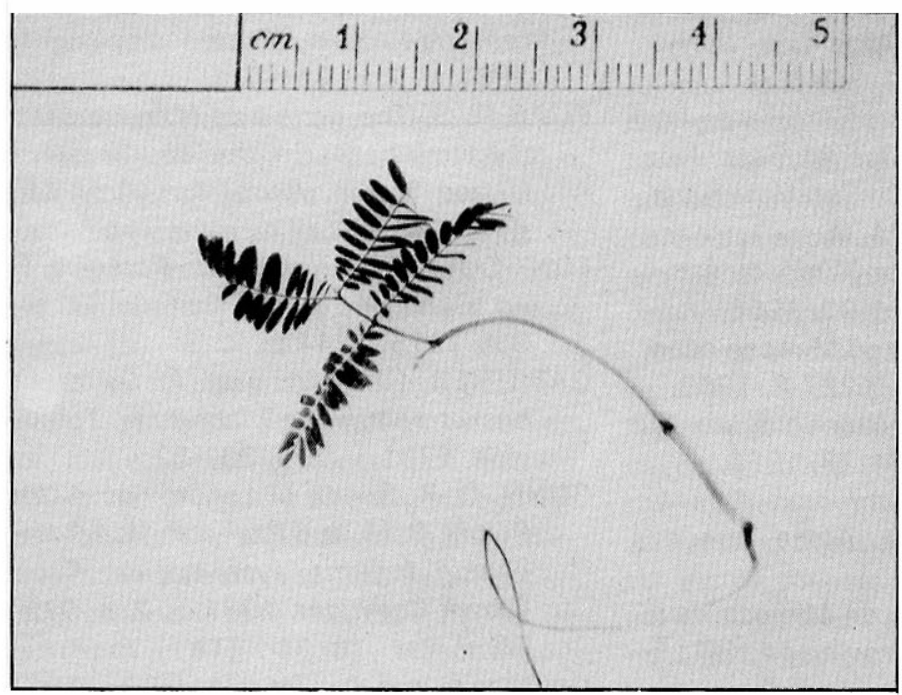

Foto 1

Plântula de Anadenanthera colubrina.

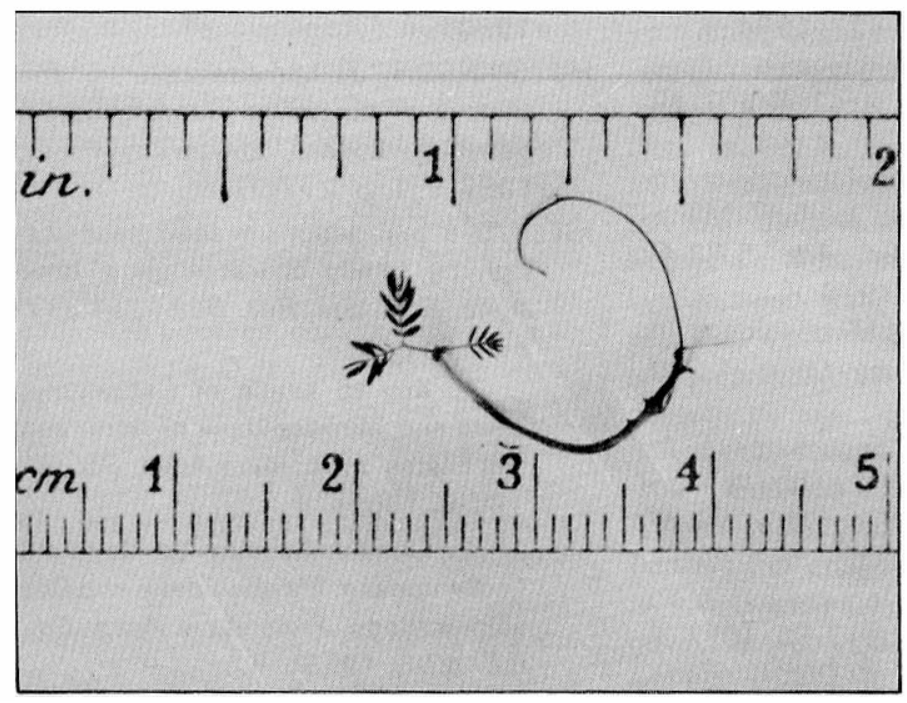

Foto 3

PIântula de Desmanthus virgatus.

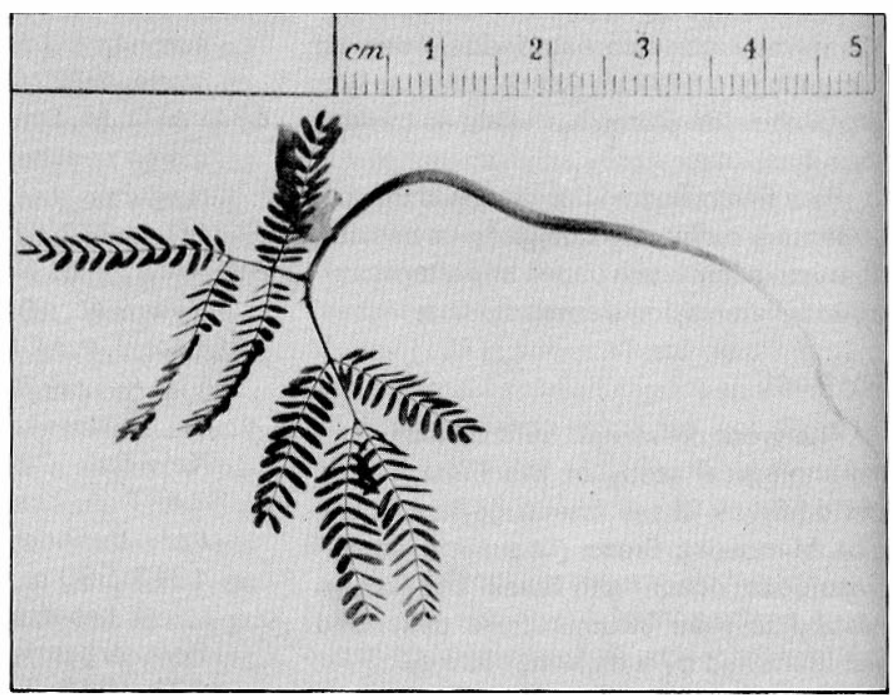

Foto 2

Plântula de Newtonia nitida.

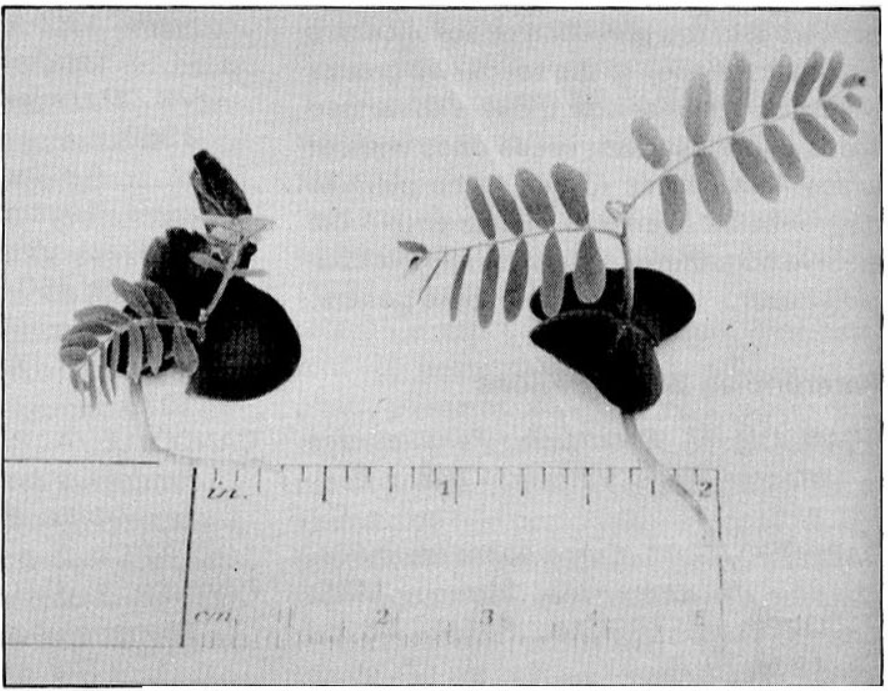

Foto 4

Plåntula de Parapiptadenia sp. 


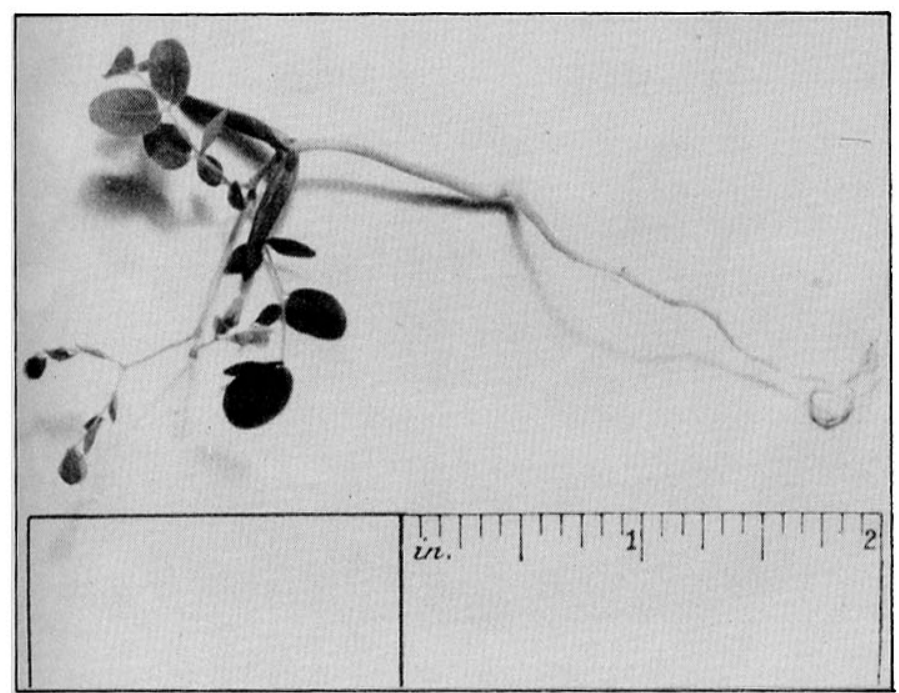

Foto 5

Plântula de Stryphnodendron adstringens.

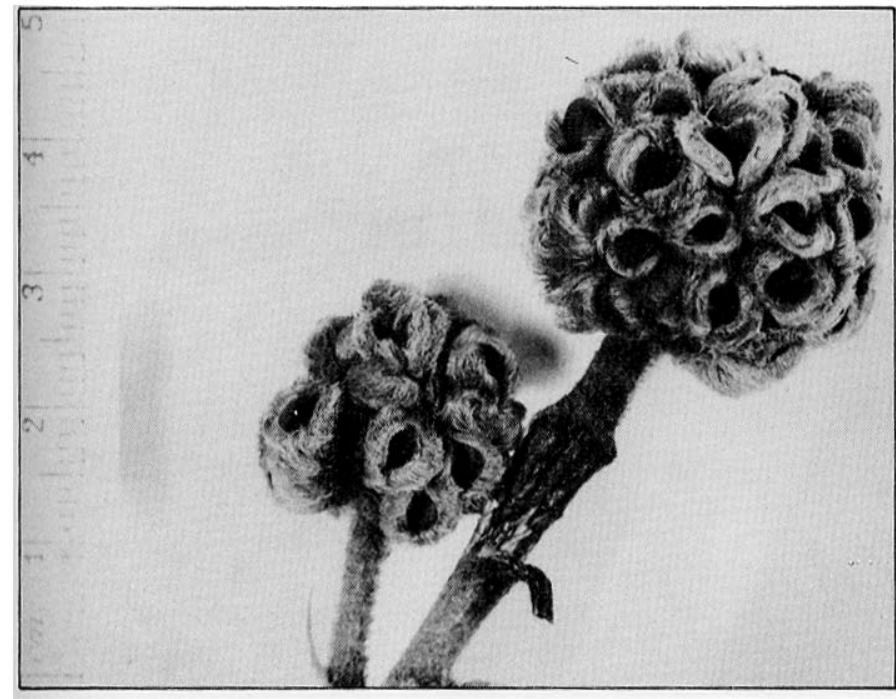

Foto 7

Sacelo de Mimosa acerba.

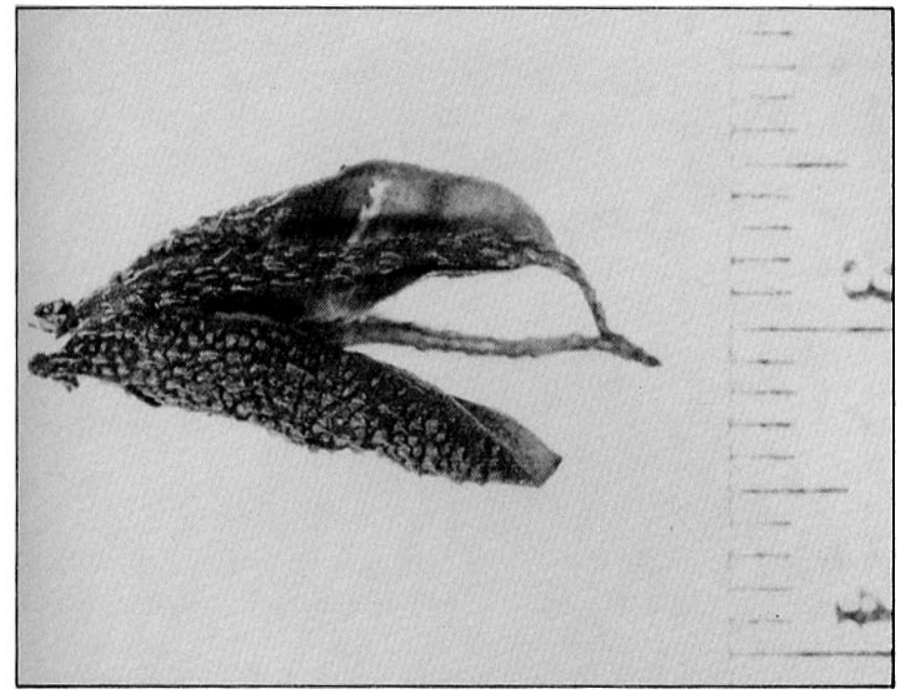

\section{Foto 9}

Craspédio indiviso de Mimosa micropteris.

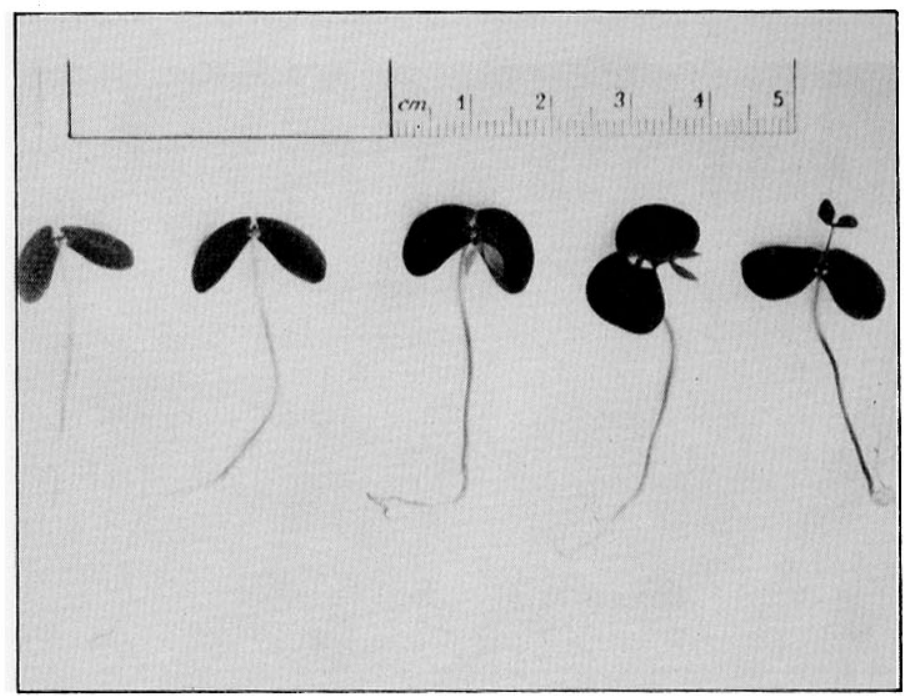

Foto 6

Plântula de Pseudopiptadenia leptostachya.

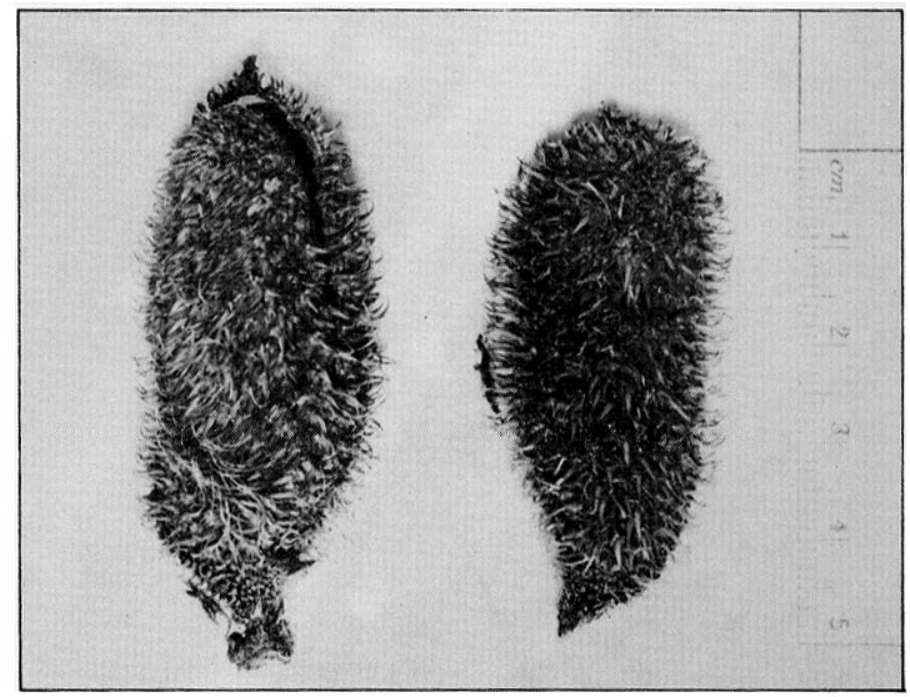

\section{Foto 8}

Craspédio indiviso de Mimosa claussenii.

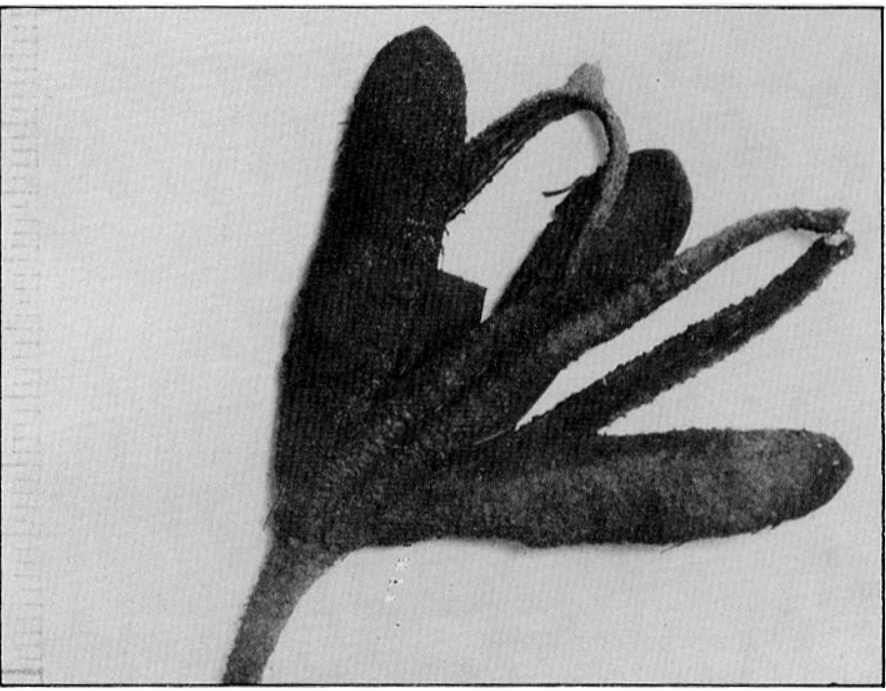

\section{Foto 10}

Craspédio indiviso de Mimosa pachycarpa. 


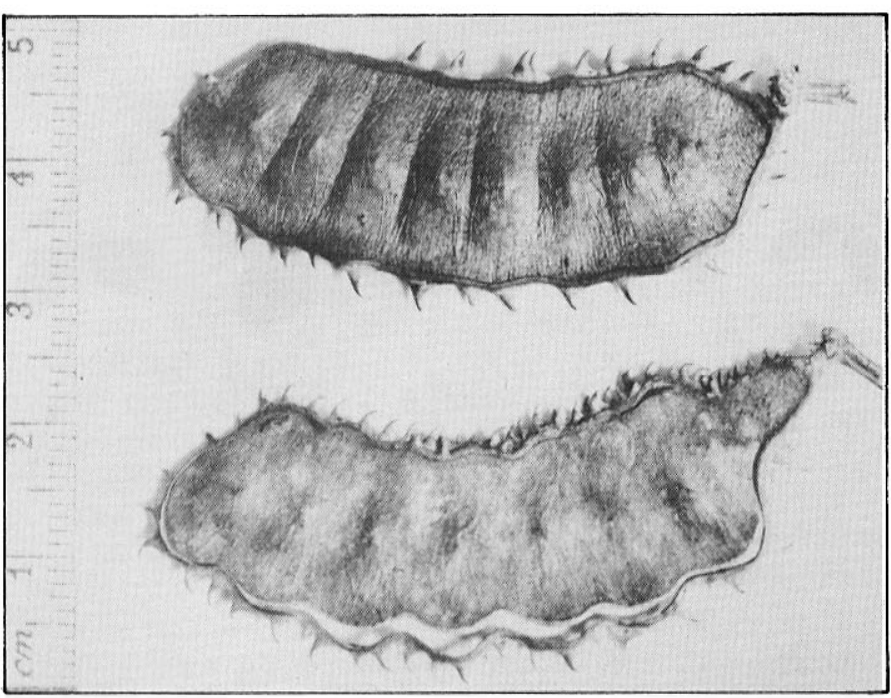

Foto 11

Craspédio indiviso de Mimosa pseudo-obovata.

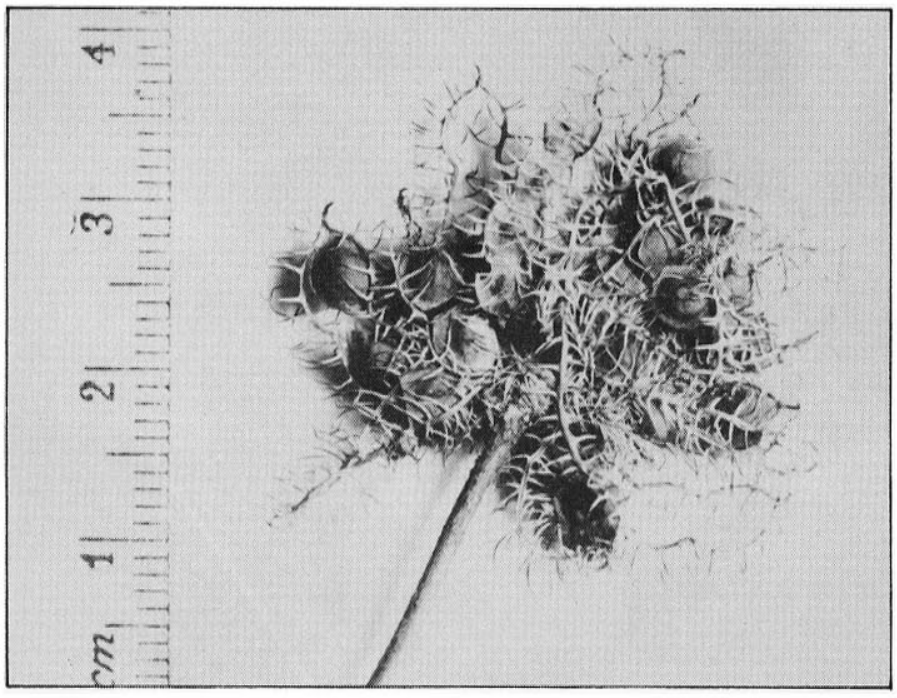

Foto 13

Craspédio articulado de Mimosa pudica.

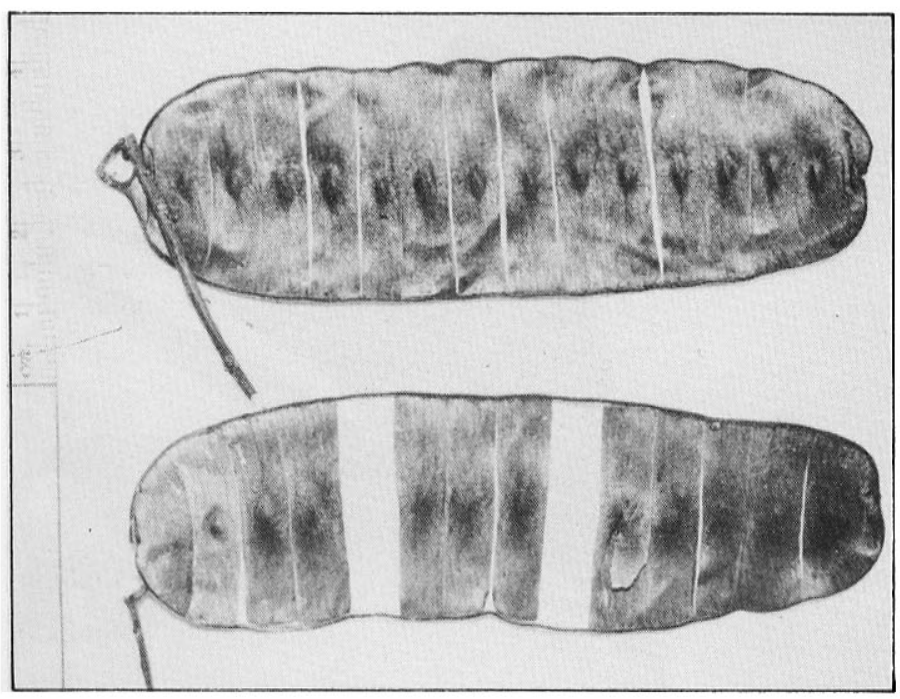

Foto 15

Craspédio articulado de Mimosa spruceana.

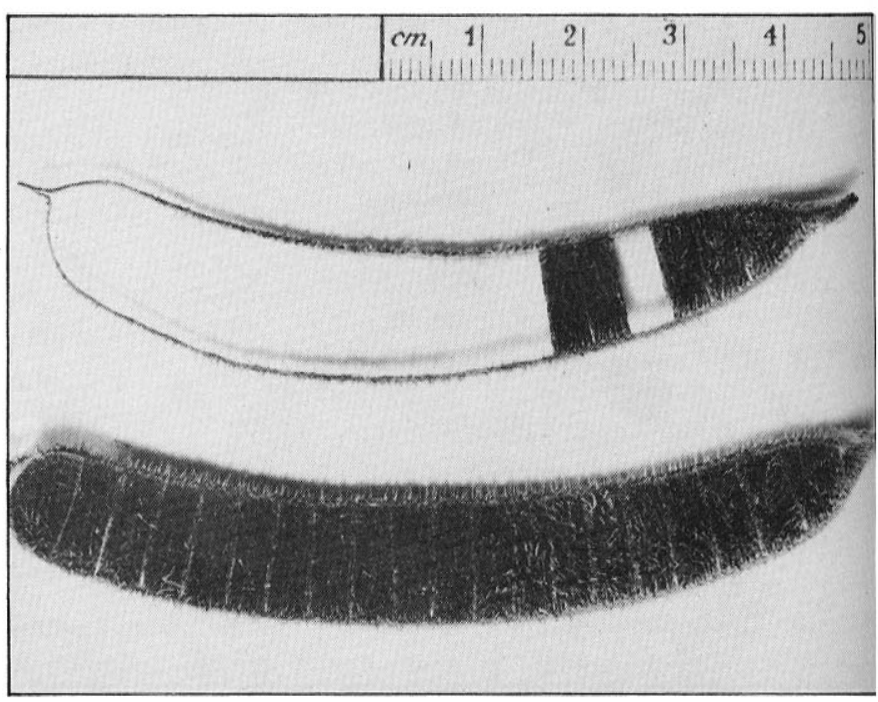

Foto 12

Craspédio articulado de Mimosa pigra.

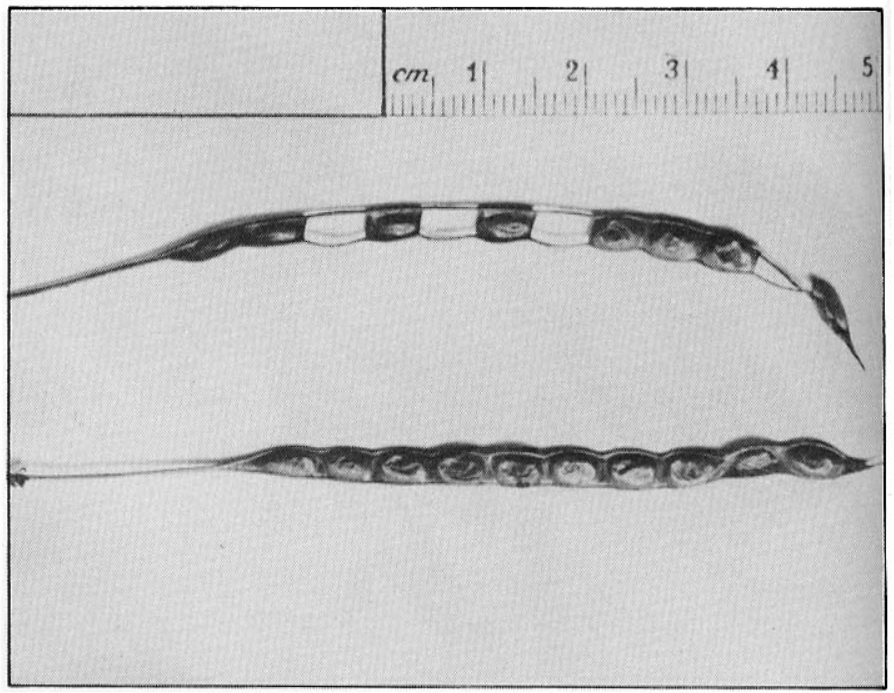

Foto 14

Craspédio articulado de Mimosa somnians.

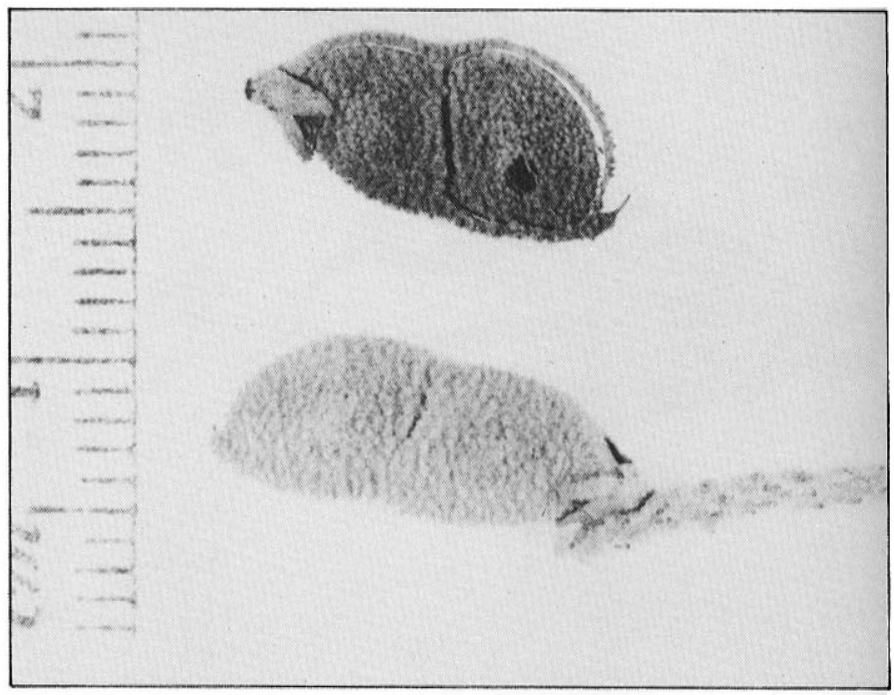

Foto 16

Craspédio articulado de Mimosa furfuracea. 


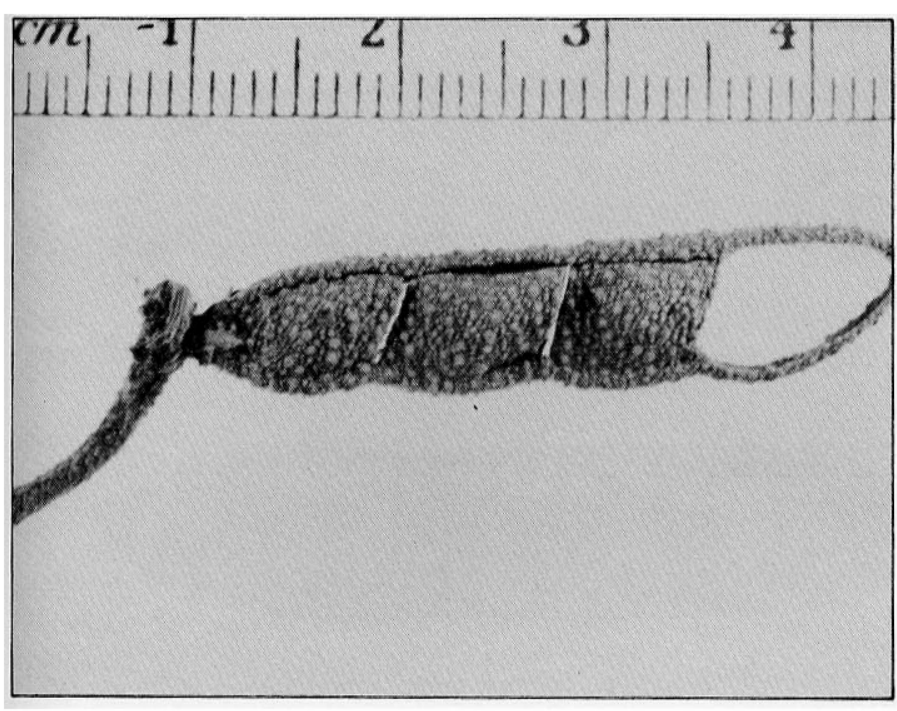

Foto 17

Craspédio articulado de Mimosa scabrel/a.

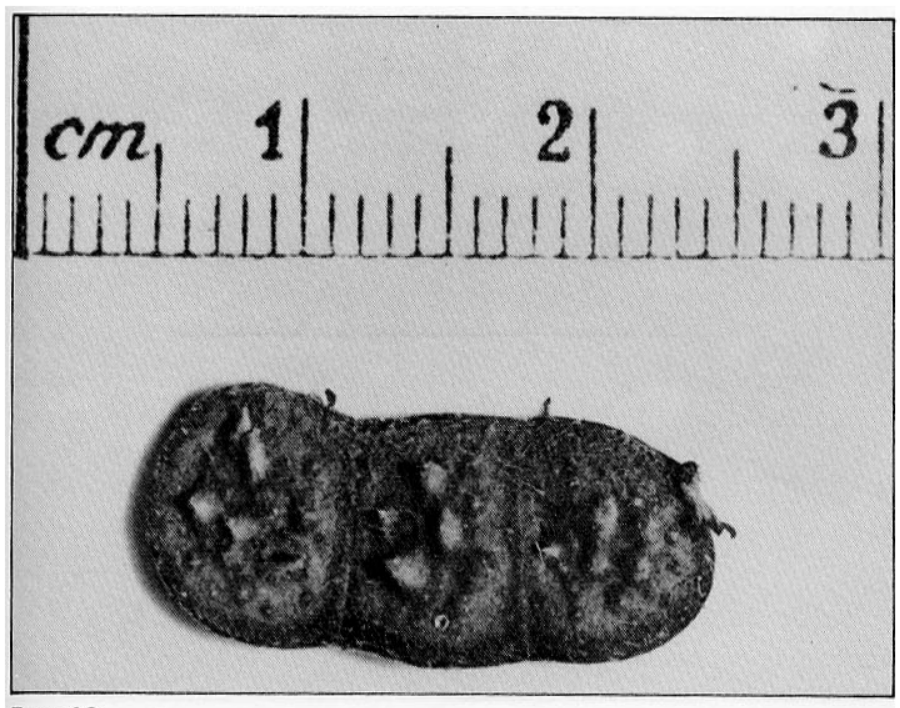

\section{Foto 19}

Craspédio articulado de Mimosa modesta.

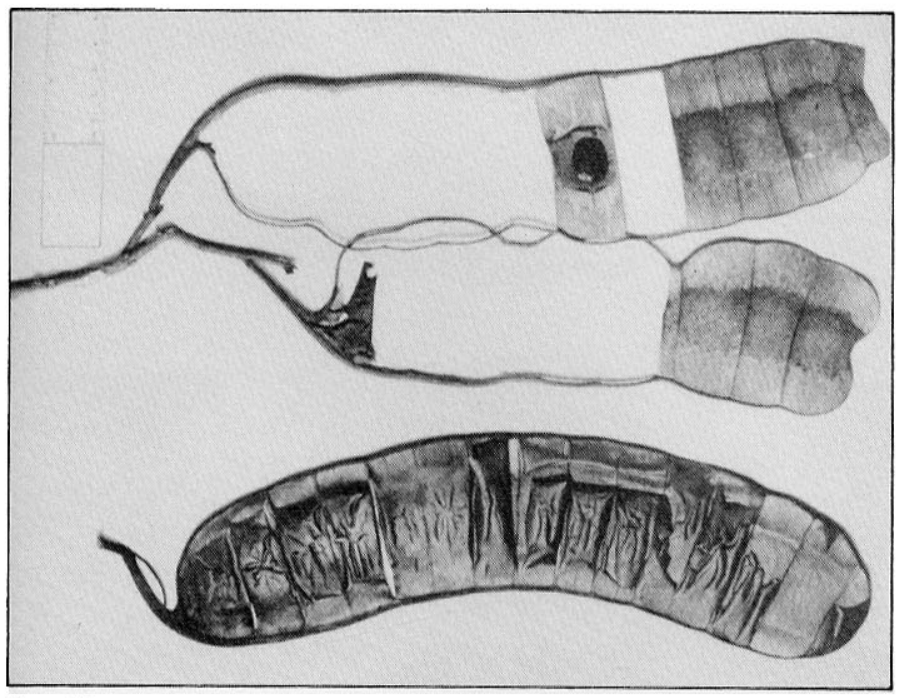

Foto 21

Craspédio articulado de Entada polystachya.

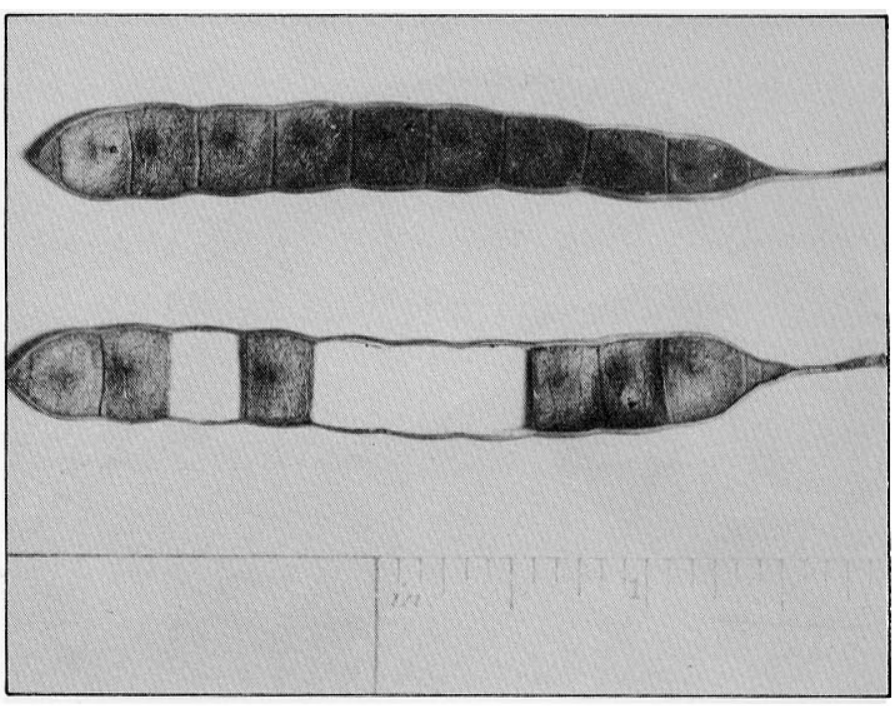

Foto 18

Craspédio articulado de Mimosa caesalpiniaefolia.

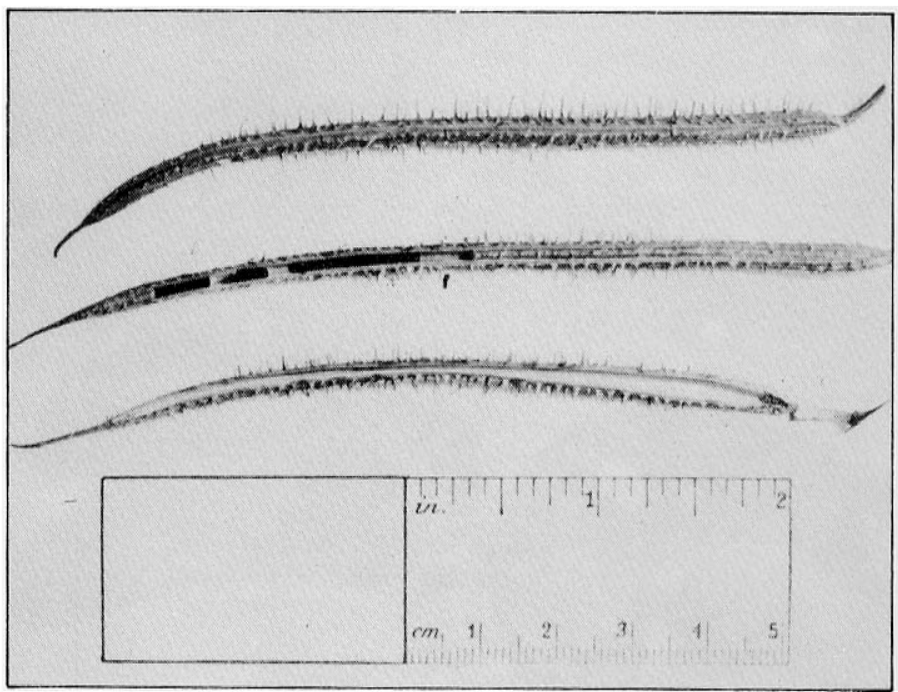

Foto 20

Craspédio de Schrankia leptocarpa.

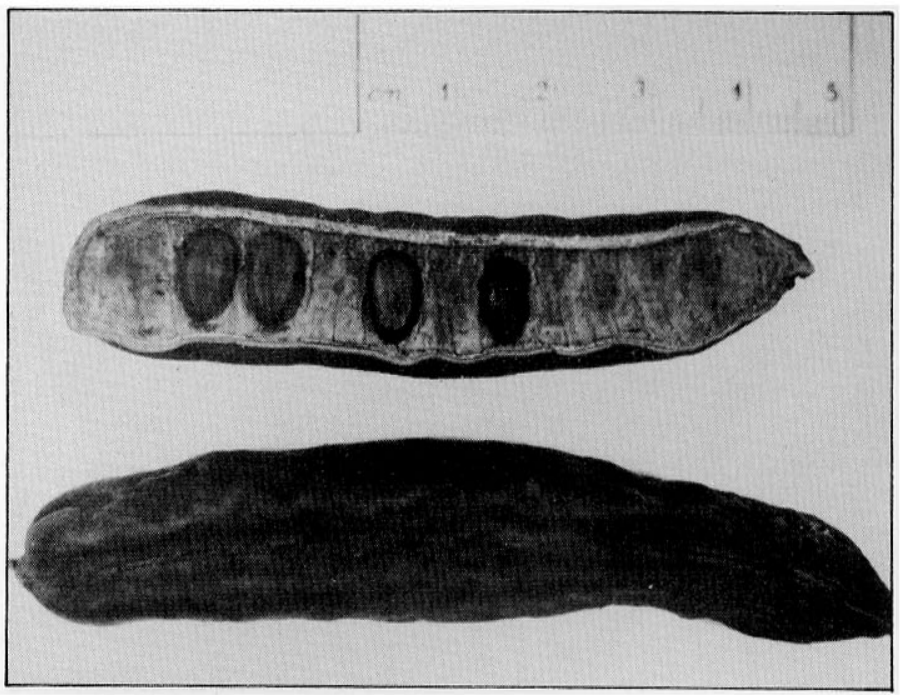

Foto 22

Legume carnoso de Stryphnodendron adstringens. 

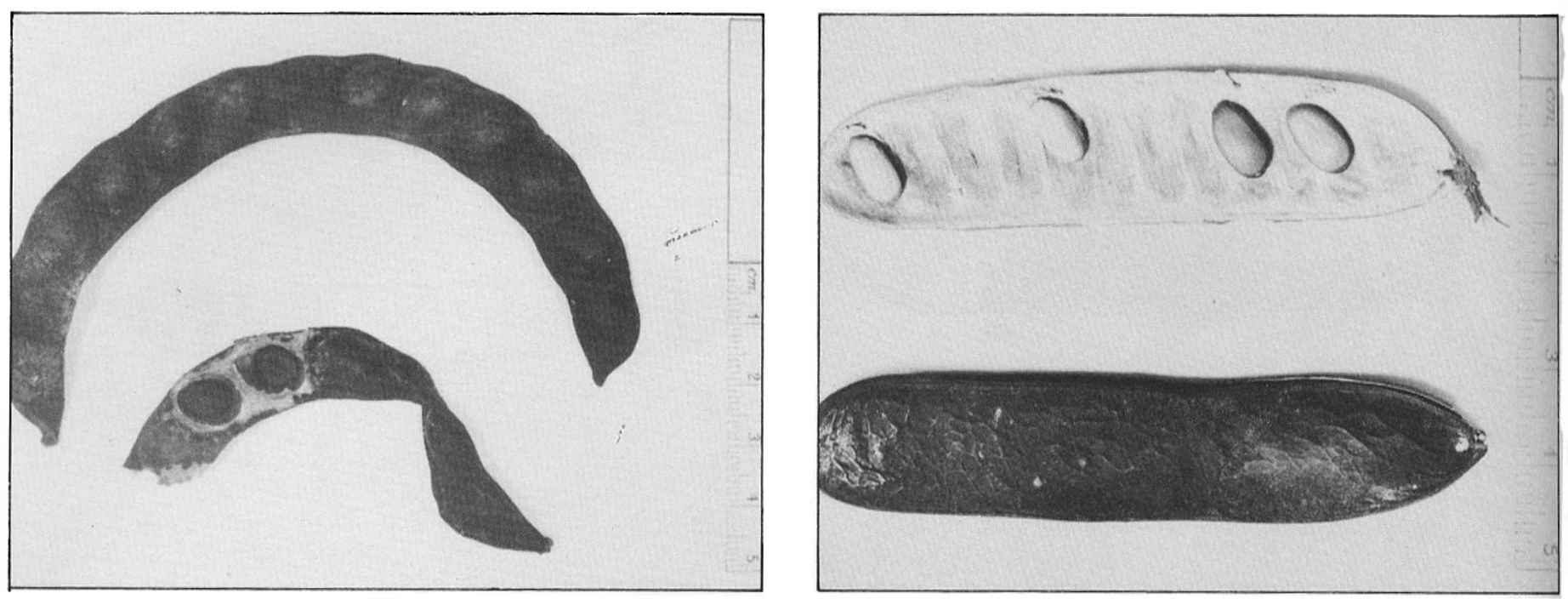

\section{Foto 23}

Legume carnoso de Stryphnodendron coriaceum.

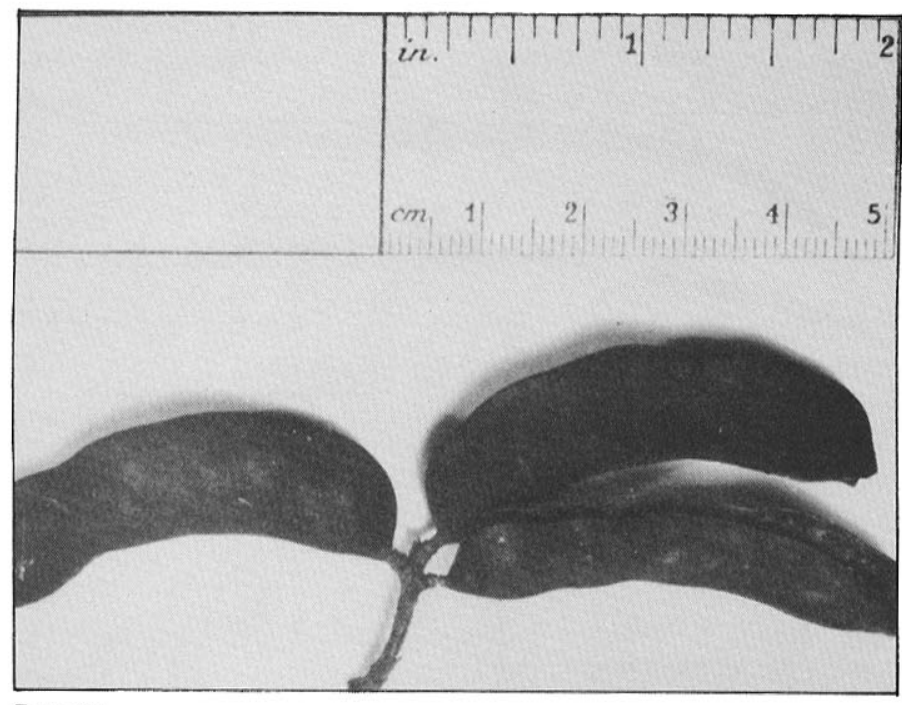

Foto 25

Foliculo de Goldmania paraguensis.

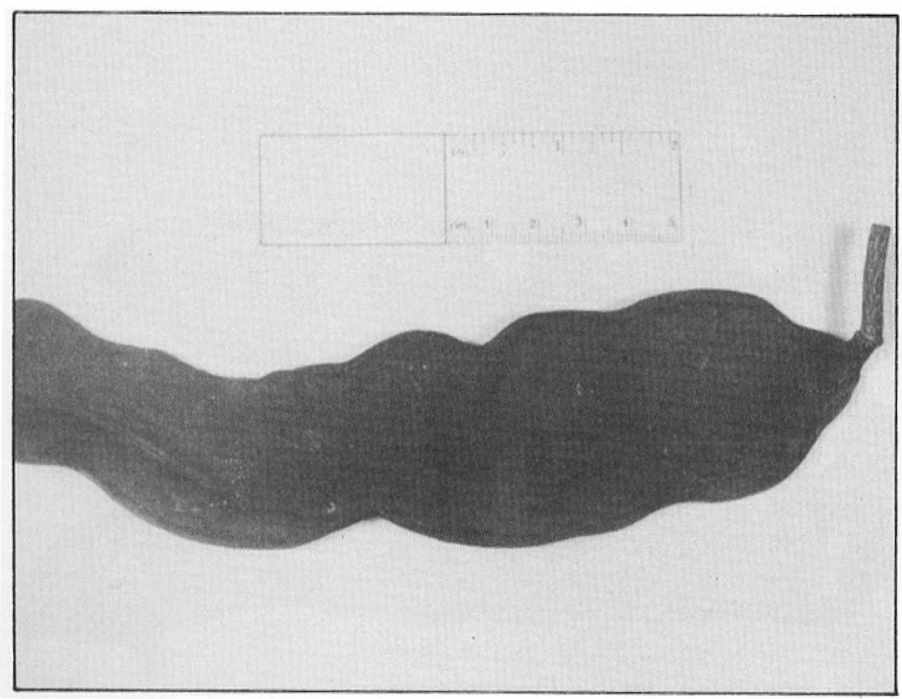

Foto 27

Folículo de Newtonia glaziovii.

\section{Foto 28}

Folículo de Anadenanthera colubrina.

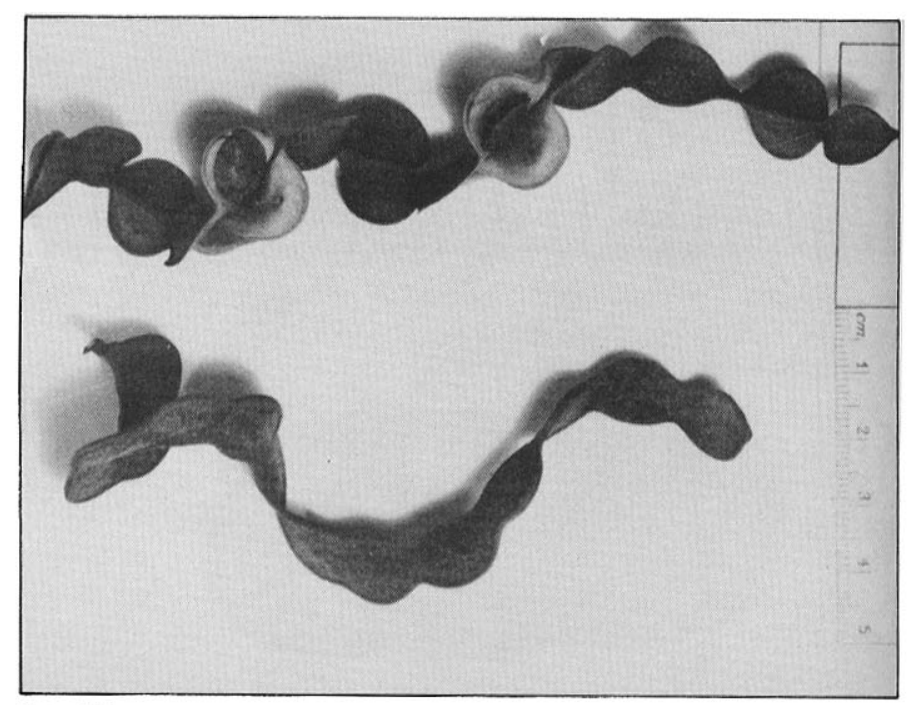

Foto 26

Foliculo moniliforme de Pseudopiptadenia leptostachya.

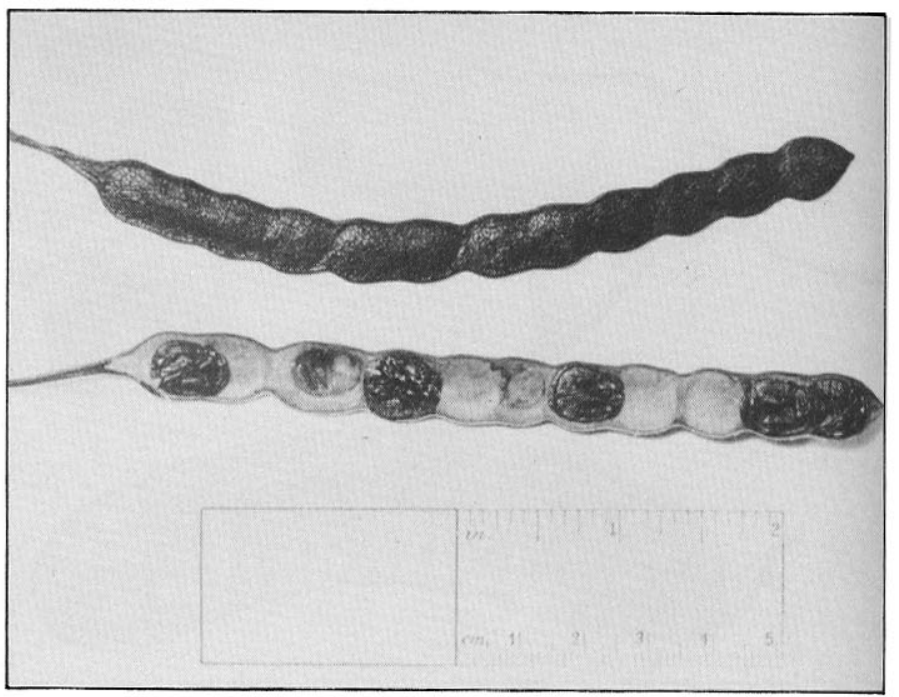




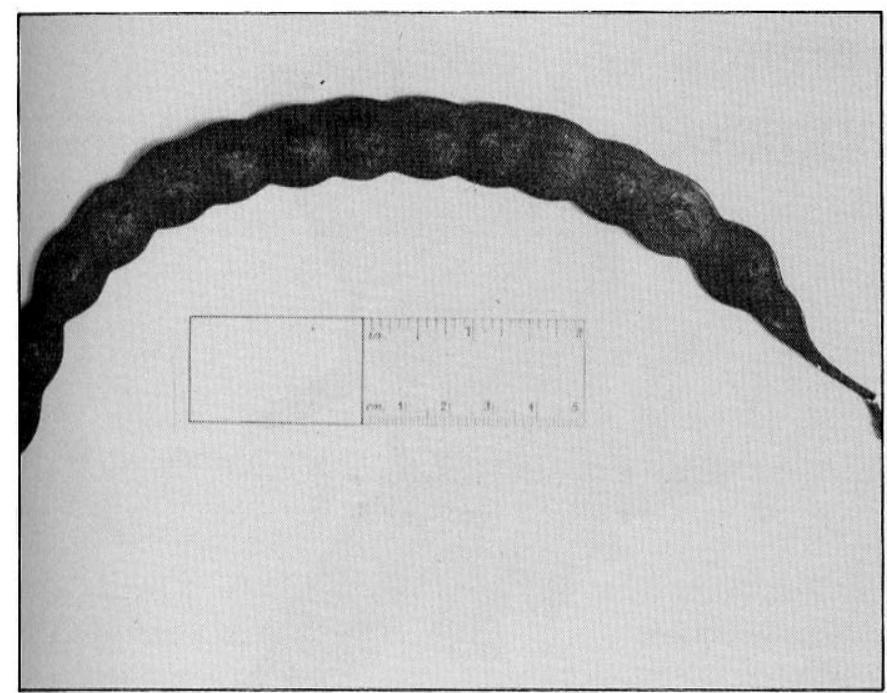

Foto 29

Folículo de Anadenanthera macrocarpa.

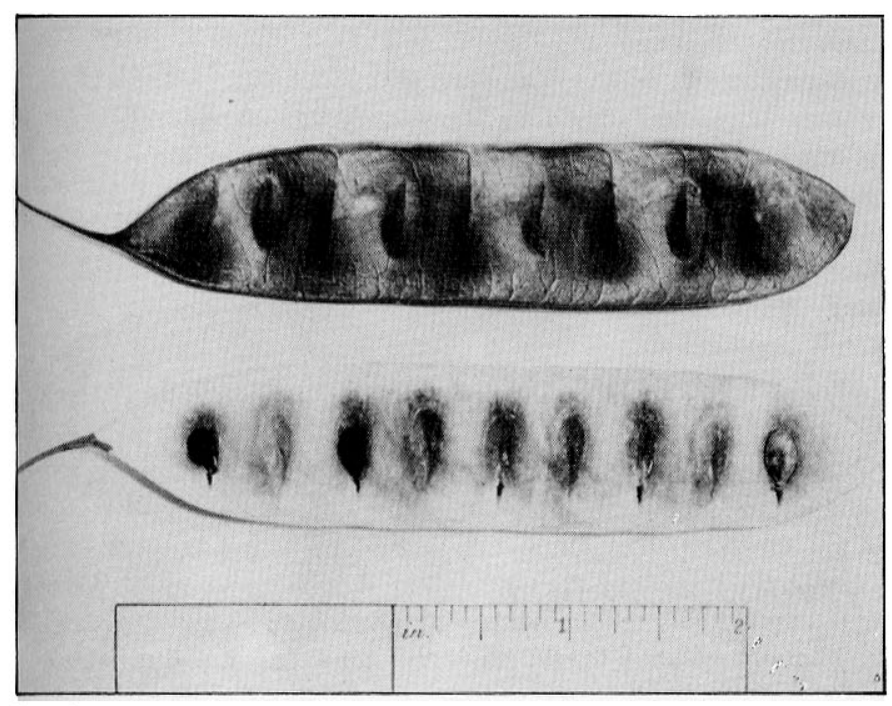

\section{Foto 31}

Legume de Piptadenia fruticosa.

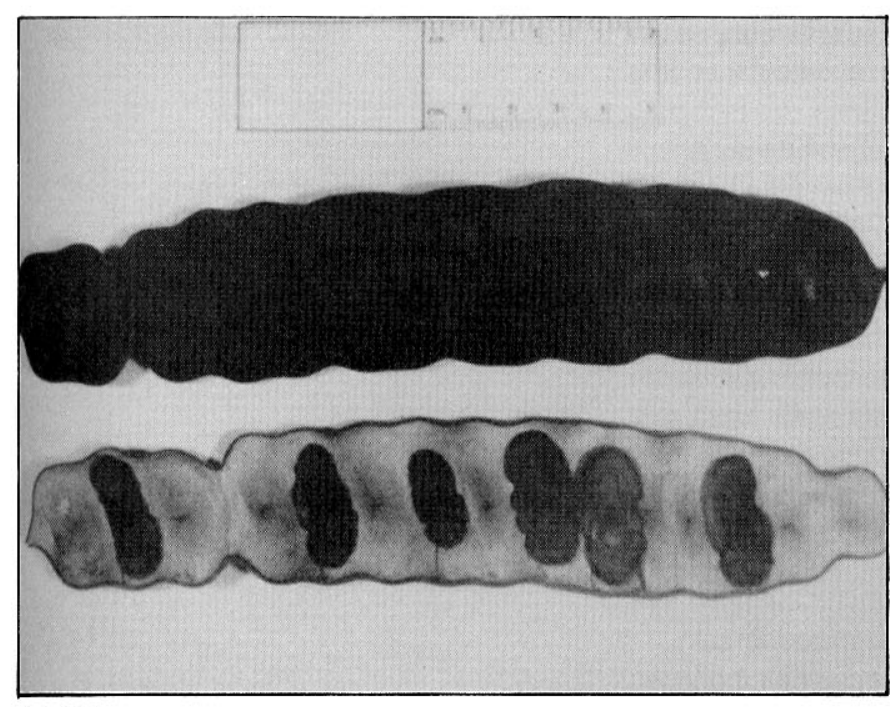

Foto 33

Legume de Parapiptadenia pterosperma.

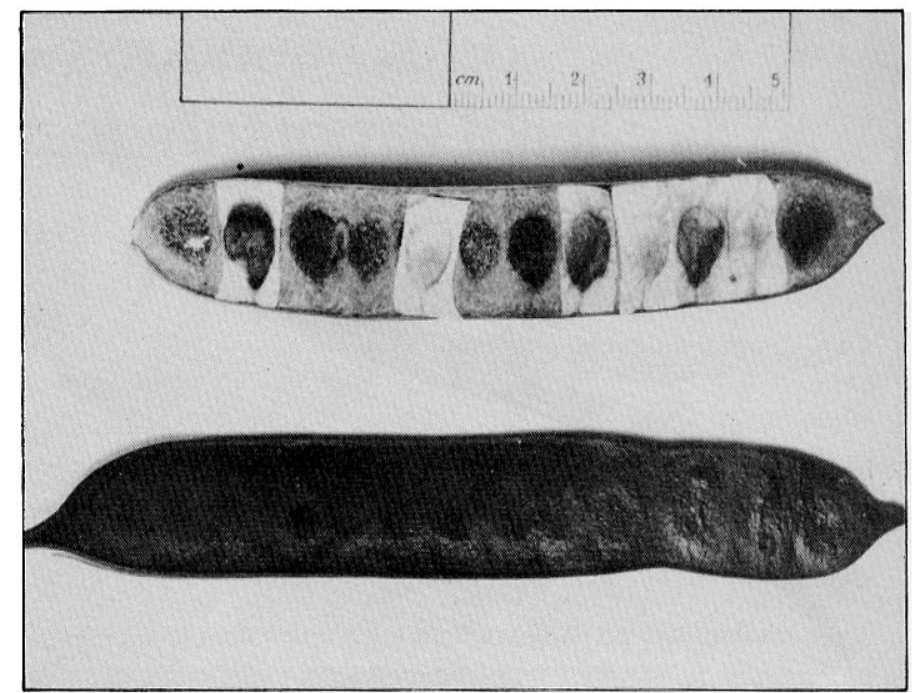

Foto 30

Criptolomento de Plathymenia foliolosa.

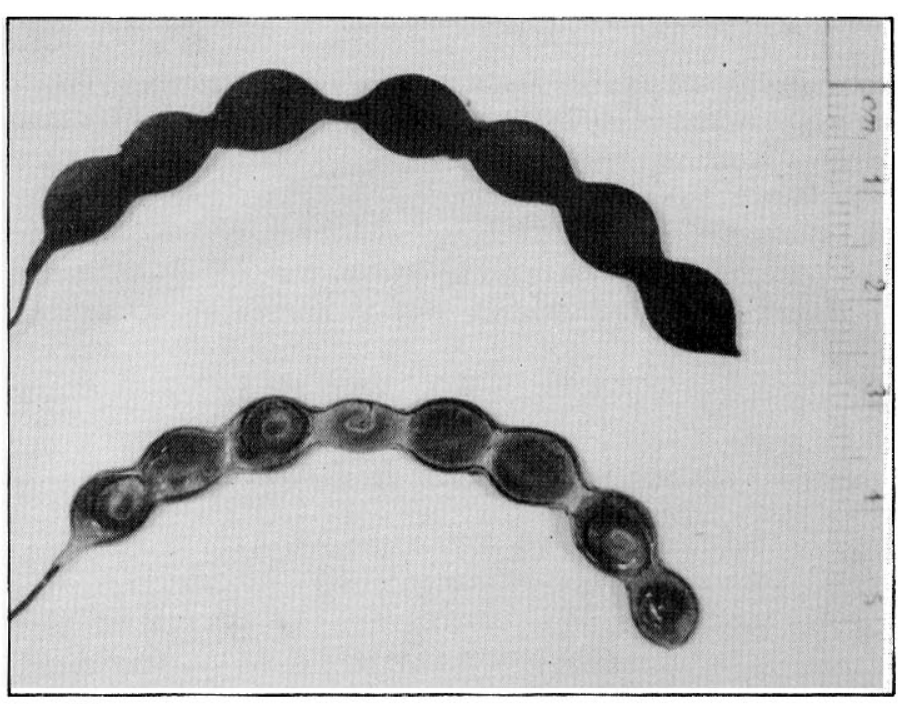

Foto 32

Legume de Piptadenia obliqua.

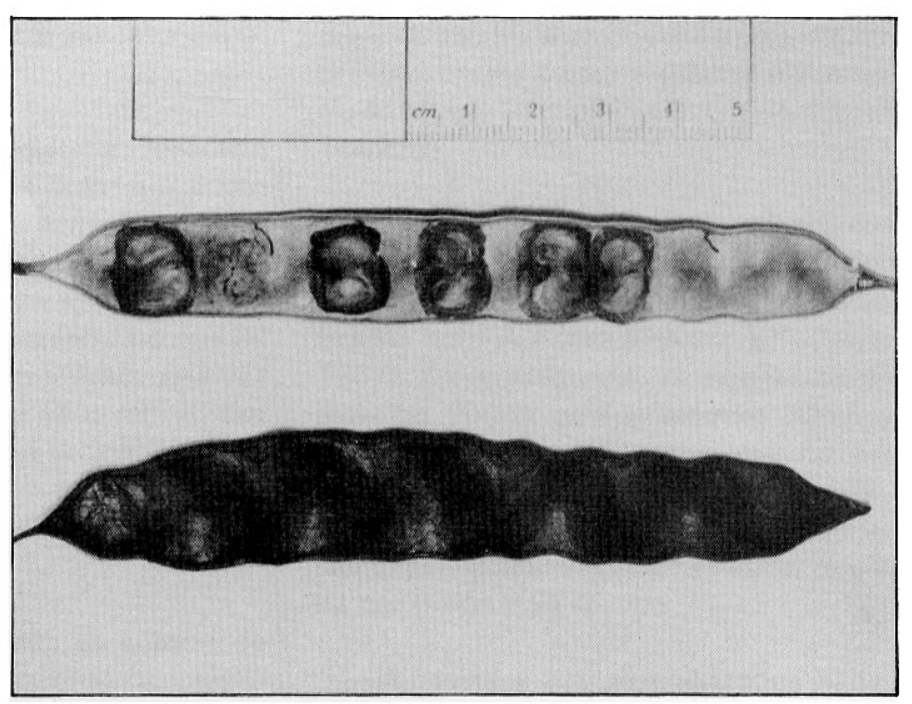

Foto 34

Legume de Parapiptadenia rigida. 


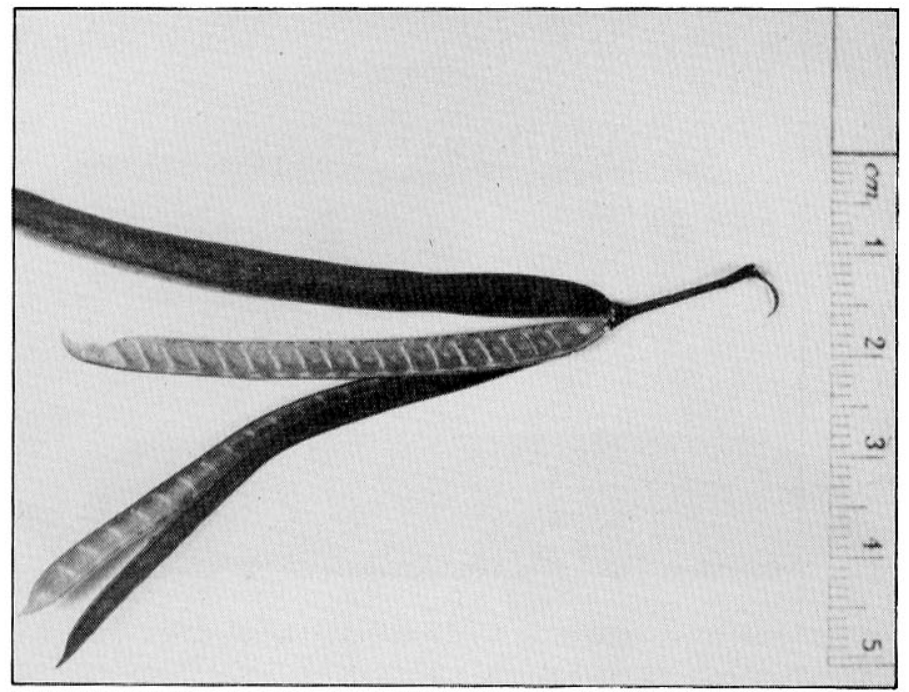

Foto 35

Legume de Desmanthus virgatus.

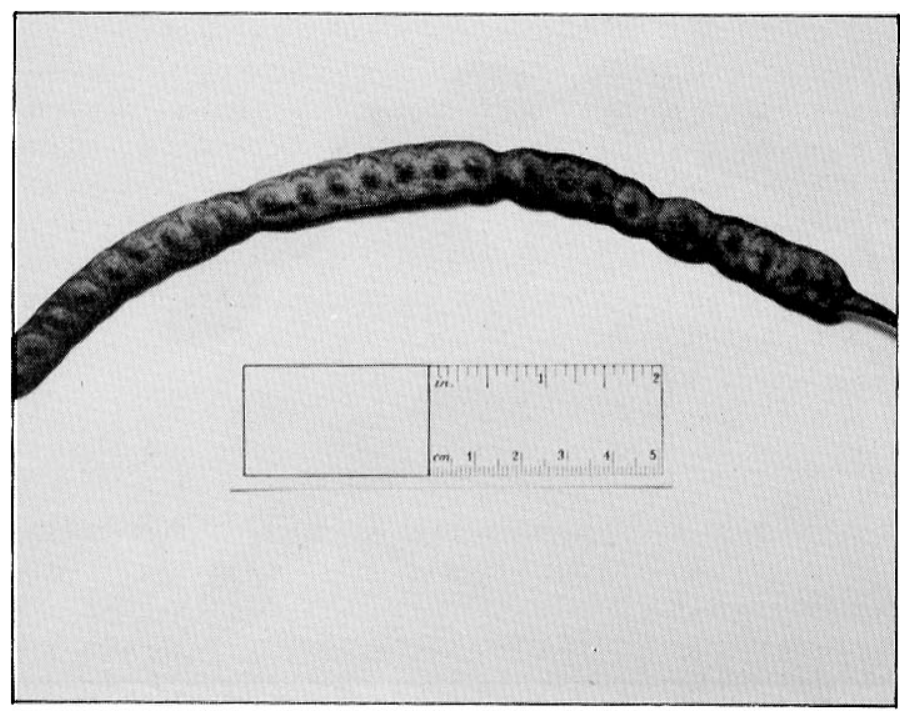

Foto 37

Lomento drupáceo de Prosopis hassleri.

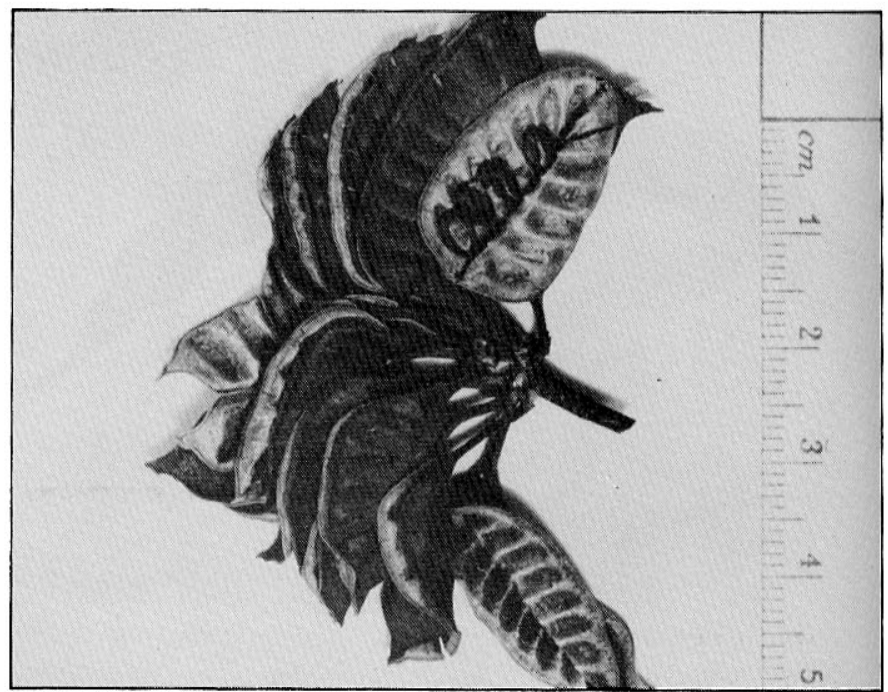

Foro 36

Legume de Neptunia oleracea.

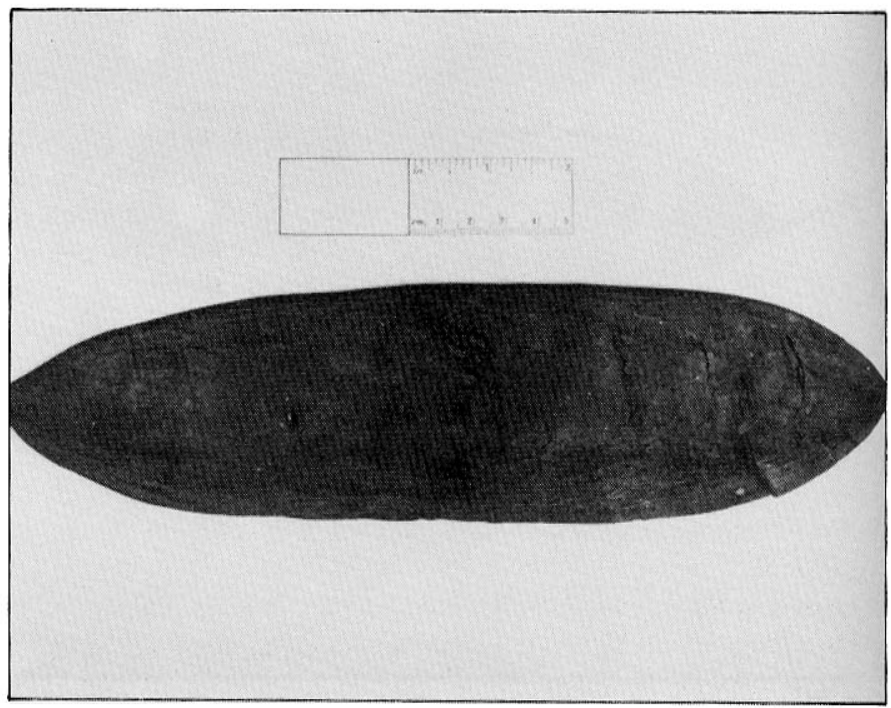

Foto 38

Samaróide de Dinizia exce/sa. 